\title{
ĢENĒTISKO FAKTORU IETEKME UZ PAPILDU KLOPIDOGRELA DEVU EFEKTIVITĀTI PERSONALIZĒTĀS TERAPIJAS NODROŠINĀŠANAI PACIENTIEM AR HIPORESPONSIVITĀTI
}

Promocijas darbs farmācijas doktora zinātniskā grāda iegūšanai Specialitāte - klīniskā farmācija 


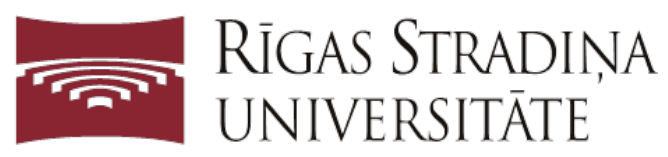

\author{
Inga Urtāne
}

\title{
ĢENĒTISKO FAKTORU IETEKME UZ PAPILDU KLOPIDOGRELA DEVU EFEKTIVITĀTI PERSONALIZĒTĀS TERAPIJAS NODROŠINĀŠANAI PACIENTIEM AR HIPORESPONSIVITĀTI
}

\author{
Promocijas darbs \\ farmācijas doktora zinātniskā grāda iegūšanai \\ Specialitāte - klīniskā farmācija \\ Darba zinātniskie vadītāji: \\ Dr. med. asociētais profesors Gustavs Latkovskis \\ Dr. pharm. docente Aina Silvija Štokmane

\section{ESF} \\ IEGULDİJUMS TAVĀ NĀKOTNẼ

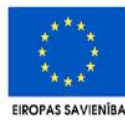 \\ Promocijas darbs veikts ar ESF projekta "Atbalsts doktorantiem studiju programmas apguvei un \\ zinātniskā grāda ieguvei Rīgas Stradiṇa universitātê” un valsts pētījumu programmas Nr. 4 \\ "Jaunu profilakses, ārstniecības, diagnostikas līdzekḷu un metožu, biomedicīnas tehnoloǵiju izstrāde \\ sabiedrības veselības uzlabošanai” projekta Nr. 1 "Aterosklerozes patoğenēzes un klīnisko izpausmju, \\ cilmes šūnu un biomateriālu pētniecība" atbalstu
}




\begin{abstract}
ANOTĀCIJA
Ievads. Samazināta reakcija uz klopidogrelu (hiporesponsivitāte) saistīta ar kardiovaskulāro (KV) notikumu risku pacientiem pēc perkutānas koronāras intervences (PCI). Lai gan klopidogrela hiporesponsivitāti ir mēǵināts pārvarēt ar papildu piesātinošām devām (PD) un lielākām uzturošām devām (UD), vēl joprojām nav skaidra ǵenētisko faktoru ietekme uz individuāli pielāgotu klopidogrela devu terapijas efektivitāti. Mērḳis. Analizēt $C Y P 2 C 19, C Y P 2 C 9$ un $A B C B 1$ ǵenētisko polimorfismu ietekmi uz klopidogrela papildu PD (600 mg) un palielinātu UD (150 mg) efektu hiporesponsivitātes pārvarēšanai, kā arī noskaidrot augstāka PRI mērķa $(<60 \%)$ drošumu ilgtermiņā 1 gada laikā. Metodes. Prospektīvā pētījumā tika iekḷauti 118 pacienti ar zālēm pārklāta stenta (DES) implantāciju. Pacientiem tika noteikts trombocītu reaktivitātes indekss (PRI), izmantojot plūsmas citometriju ar vazodilatatorstimulējošā fosfoproteīna (VASP) metodi. Visiem pacientiem noteikti sekojoši ǵenētiskie polimorfismi: $C Y P 2 C 19, C Y P 2 C 9$ un $A B C B 1$. Samazinātas klopidogrela darbības gadījumā (PRI $\geq 60 \%$ ) pacienti saṇēma līdz 3 papildu 600 mg PD, atkārtoti pārbaudot PRI. Apsekošanas vizītes pēc 40 dienām tika veiktas visiem pacientiem, lietojot $75 \mathrm{mg}$ UD un papildus pēc 10 dienām tiem, kuri lietoja $150 \mathrm{mg}$ UD. Ilgtermiņa klīniskā apsekošana veikta visiem pacientiem. Rezultāti. Samazinātu klopidogrela darbību pirmajā VASP analīzē novēroja 68 pacientiem (72,3\%). PRI bija augstāks pacientiem ar CYP2C19*2 polimorfismu, salīdzinot ar biežāk sastopamo (wild-type) genotipu, attiecīgi 78,2 $\pm 13,1$ un $65,3 \pm 19,5 ; \mathrm{p}=0,005$. Pēc pirmās papildu $600 \mathrm{mg}$ PD mazāks PRI samazinājums bija pacientiem ar CYP2C19*2 polimorfismu $(25,5 \pm 15,6$ un $35,5 \pm 16,8 ; \mathrm{p}=0,025)$. Pacientiem ar CYP2C19*2 bija augstāks PRI pie

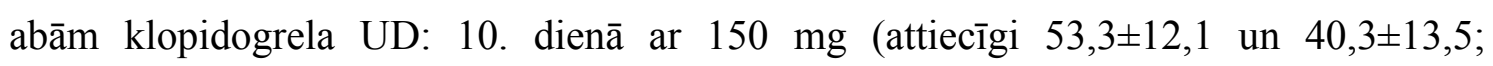

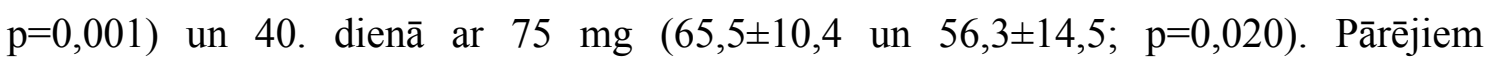
polimorfismiem nozīmīgu saistību ar PRI neatrada. Pacientiem ar hiporesponsivitāti bija

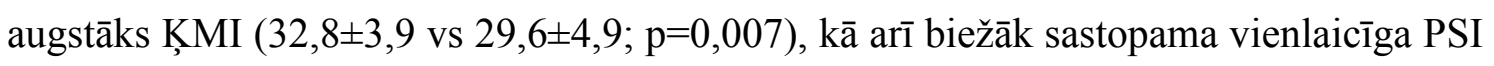
terapija (16 vs 7; $\mathrm{p}=0,381$ ). Secinājumi. Pacientiem ar vismaz vienu CYP2C19*2 alēli klopidogrela standarta PD un papildu PD efektivitāte ir pazemināta. Šīs alēles nēsātājiem augstāka $150 \mathrm{mg}$ klopidogrela UD ir efektīvāka, bet joprojām nav pietiekama 29\% gadījumu. Augstāks ķermeņa masas indekss (ĶMI) un protonu sūkṇa inhibitoru (PSI) lietošana asociējas ar tendenci uz samazinātu klopidogrela efektivitāti.
\end{abstract}




\section{ANNOTATION}

Introduction. Hyporesponsiveness to clopidogrel has been associated with increased risk of cardiovascular events for patients undergoing percutaneous coronary intervention (PCI). Low response to clopidogrel (hyporesponsivevess) may be overcome by additional loading doses (LD) and higher maintenance doses (MD). The influence of genetic polymorphisms on efficacy of personalized clopidogrel dosing remains unclear. The aim of this study was to investigate whether genetic polymorphisms of two cytochromes (CYP2C19, CYP2C9) and ABCB1 modify effect of additional LDs (600 mg) and higher MD (150 mg) used to overcome hyporesponsiveness of clopidogrel and to evaluate long-term safety of higher platelet reactivity index (PRI) cutoff value of $<60 \%$ during one year period after PCI. Methods. In a prospective single-center study we enrolled 118 patients undergoing PCI with drugeluting stent (DES). PRI was measured using the Vasodilator-Stimulated Phosphoprotein index (VASP). Genetic polymorphisms of CYP2C19, CYP2C9 and $A B C B 1$ were determined. In patients hyporesponsive to the initial LD the doseadjustment was performed using up to 3 additional $600 \mathrm{mg}$ LDs in order to achieve PRI $<60 \%$, and both $150 \mathrm{mg}$ and $75 \mathrm{mg} \mathrm{MD}$ were tested at the follow-up. Long-term clinical follow up was obtained in all patients. Results. Patients with at least one CYP2C19*2 allele had higher baseline PRI after the initial LD $(78.2 \pm 13.1$ vs $65.3 \pm 19.5, \mathrm{p}=0.005)$. The PRI reduction with additional LD was significantly smaller in carriers of the CYP2C19*2 $(25.2 \pm 15.6$ vs $35.5 \pm 16.8, \mathrm{p}=0.025)$ and similar trend was observed with additional LDs. Both MDs were less effective in presence of $C Y P 2 C 19 * 2: 53.3 \pm 12.1$ vs $40.3 \pm 13.5$, respectively; $p=0.001$ on day 10 while on MD of $150 \mathrm{mg}$, and $65.5 \pm 10.4$ vs $56.3 \pm 14.5$, respectively; $\mathrm{p}=0.020$ on day 40 on $\mathrm{MD}$ of $75 \mathrm{mg}$. No such differences were observed for other polymorphisms. Low responders to clopidogrel had higher body mass index (BMI) (32.8 \pm 3.9 vs 29.6 $\pm 4.9 ; \mathrm{p}=0.007)$. More patients in hyporesponders group had concomitantly proton pump inhibitor (PPI) therapy compared to responders (16 vs 7; $\mathrm{p}=0.381$ ). Conclusions. The patients carrying at least one loss-of-function CYP2C19*2 allele have significantly higher PRI following an initial LD and additional LDs. In the presence of $C Y P 2 C 19^{*} 2$ higher MD of clopidogrel $(150 \mathrm{mg})$ was more effective but still remains insufficient in $29 \%$ of cases. Higher BMI and use of PPIs were associated with a trend to decreased efficiency of clopidogrel. 


\section{SATURS}

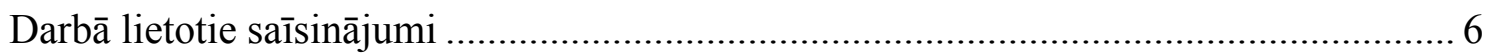

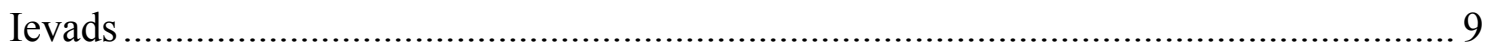

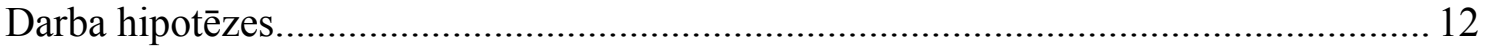

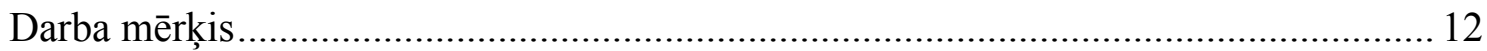



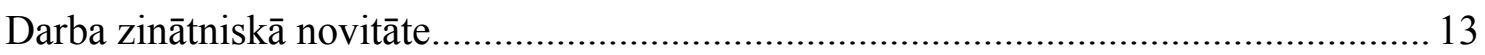

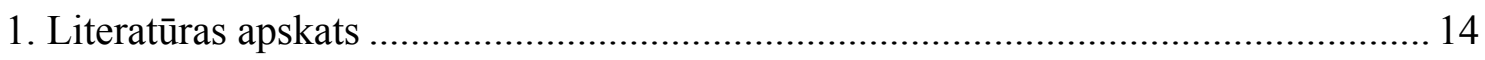

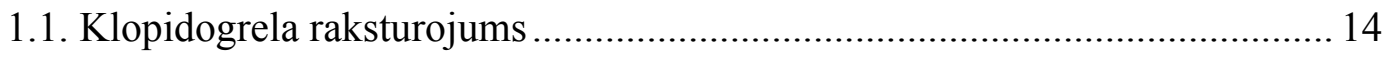

1.2. Klopidogrela neefektivitātes definēšana ....................................................... 16

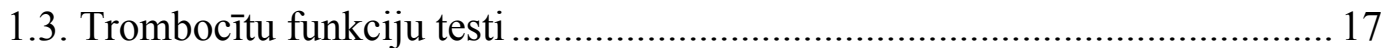

1.4. Klopidogrela efektivitātes variabilitāti ietekmējošie faktori ......................... 22

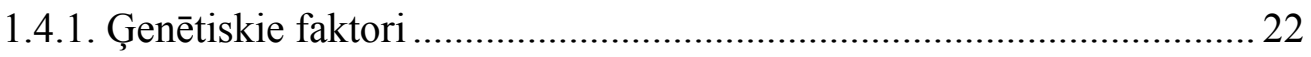

1.4.2. Celulārie faktori......................................................................... 28

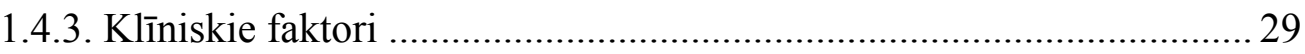

1.5. Pacientu uzraudzība ar samazinātu klopidogrela atbildes reakciju ................ 40

1.6. Jaunākie antiagreganti, to priekšrocības un trūkumi ...................................... 41

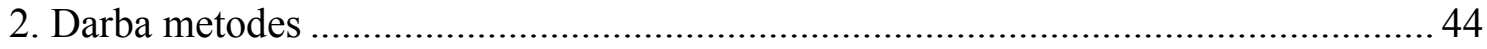

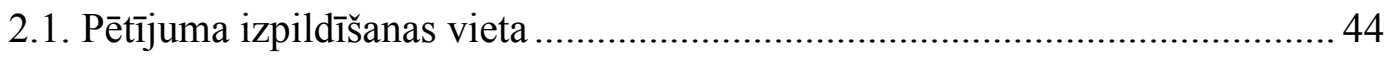

2.2. Pētījuma dizains un kopējās pacientu grupas atlases principi ....................... 44

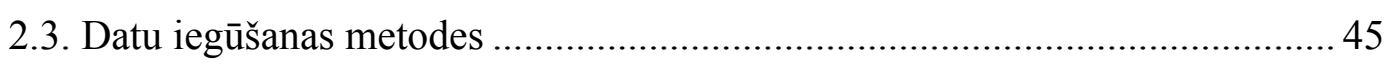

2.3.1. Apkopotā informācija par fenotipu .................................................. 45

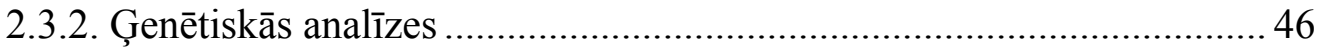

2.3.3. Klopidogrela rezistences analīze.................................................... 47

2.3.4. Datu statistiskās apstrādes metodes ................................................... 54

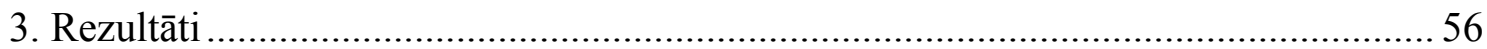

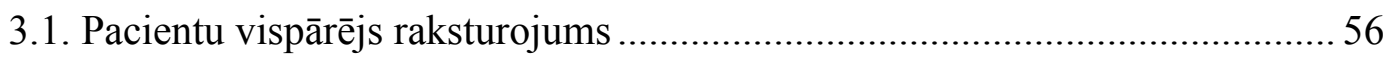

3.2. PRI variabilitāte pēc pirmās klopidogrela PD ............................................. 58

3.3. Klopidogrela papildu PD efekts pacientiem ar PRI1 $\geq 60 \% \ldots \ldots \ldots \ldots \ldots \ldots \ldots \ldots . . . .60$

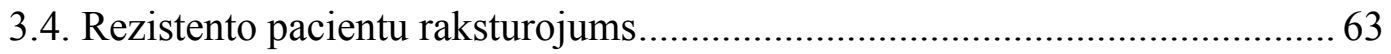

3.5. Pacientu kopas ǵenētiskais raksturojums .................................................... 63

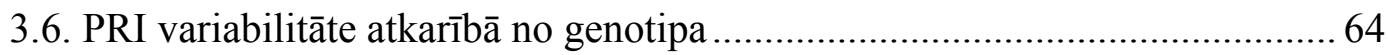


3.6.1. PRI1 rezultāti atkarībā no $C Y P 2 C 19, C Y P 2 C 9$ un $A B C B 1$ genotipiem....

3.6.2. PRI2 rezultāti atkarībā no $C Y P 2 C 19, C Y P 2 C 9$ un $A B C B 1$ genotipiem.....

3.6.3. PRI3 rezultāti atkarībā no $C Y P 2 C 19, C Y P 2 C 9$ un $A B C B 1$ genotipiem.

3.6.4. PRI4 rezultāti atkarībā no $C Y P 2 C 19, C Y P 2 C 9$ un $A B C B 1$ genotipiem 72

3.6.5. 10. un 40. dienas apsekošanas vizītes PRI rezultāti atkarībā no CYP2C19, CYP2C9 un $A B C B 1$ genotipiem

3.6.6. PD skaits atkarībā no $C Y P 2 C 19, C Y P 2 C 9$ un $A B C B 1$ genotipiem ..... 81

3.7. Prehospitālās farmakoterapijas un esošu slimību ietekme uz PRI ................ 84

3.8. Vispārējo un anamnnēzes datu salīdzinājums atkarībā no PRI1 .................... 86

3.8.1. ĶMI ietekme uz klopidogrela papildu PD un augstāku UD efektivitāti 89

3.8.2. PSI ietekme uz klopidogrela papildu PD un augstāku UD efektivitāti .95

3.9. Pacientu ilgtermiņa apsekošanas rezultāti ................................................. 97

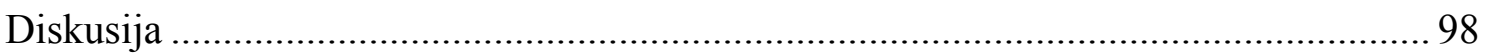

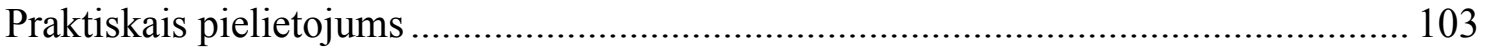



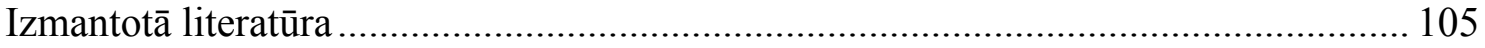

Publikācijas un ziņojumi par pētījuma tēmu ................................................................ 123

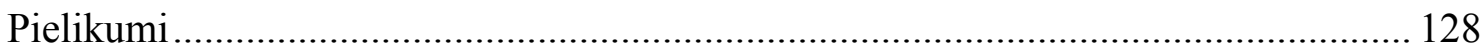




\section{DARBĀ LIETOTIE SAĪSINĀJUMI}

A2RB - angiotenzīna II receptoru blokatori

ABCB1 - TF saistītās kasetes apakšsaimes B 1. loceklis

ABLH - augsta blīvuma liporoteīnu holesterīns

$\mathrm{AC}$ - adenilciklāze

ADF - adenozīna difosfāts

$\mathrm{AH}$ - arteriāla hipertensija

AKEI - angiotenzīnu konvertējošā enzīma inhibitori

AKS - akūts koronārs sindroms

ALAT - alanīnaminotransferāze

ANOVA - variācijas analīze (analysis of variance)

APTL - aktivētais parciālais tromboplastīna laiks

ASAT - aspartātaminotransferāze

ASV - Amerikas Savienotās Valstis

ATF - adenozīna trifosfāts

$\mathrm{BB}$ - beta blokatori

BMC - Biomedicīnas pētījumu un studiju centrs

CABG - koronāro artēriju šuntēšana (coronary artery bypass grafting)

cAMF - cikliskais adenozīna monofosfāts

CD - cukura diabēts

$\mathrm{CI}$ - cerebrāls infarkts jeb insults

CK-MB - kreatīnkināzes MB frakcija

CRO - C-reaktīvais olbaltums

CYP - citohroms

DAG - diacilglicerols

DAPT - duāla antiagregantu terapija (dual antiplatelet therapy)

DES - ar zālēm pārklāts stents (drug eluting stent)

DNS - dezoksiribonukleīnskābe

EDTA - etilēndiamīntetraacetāts (antikoagulants) 
$\mathrm{EF}$ - izsviedes frakcija (efection fraction)

FITC - fluerescīna izotiocianāts

FLC - fosfolipāze C

FUP - novērošana/apsekošana (follow up)

$\mathrm{Gi}-\mathrm{G}$ inhibējošais proteīns

GP - glikoproteīns

$\mathrm{Hb}_{\mathrm{A} 1 \mathrm{C}}-$ glikētais hemoglobīns

HMG-CoA - 3-hidroksi-3-metilglutarilkoenzīms A

HNS - hroniska nieru slimība

HSM - hroniska sirds mazspēja

INR - starptautiska normalizēta protrombīna laika attiecība

IP3 - inozitiltrifosfāts

IVUS - intravaskulārā ultrasonoskopija

$\mathrm{KH}$ - kopējais holesterīns

$\mathrm{KK}$ - sirds kreisais kambaris

KKB - kalcija kanālu blokatori

KSS - koronārā sirds slimība

KV - kardiovaskulārs

ĶMI - ķermeņa masas indekss

LKC - Latvijas Kardiolog̣ijas centrs

LTA - gaismas transmisijas agregometrija

MDR1 - multizāļu rezistences proteīns 1

MEA - multielektrodu agregometrija

MFI - vidējā fluorescences intensitāte

MFIc - vidējā fluorescences intensitāte (aprēķinos)

MI - miokarda infarkts

MLKC-P - miozīnkināzes fosforilācija

MVA - daudzmain̄̄go analīze (multivariate analysis)

NPL - nesteroīdie pretiekaisuma līdzekḷi

NSTEMI - miokarda infarkts bez ST segmenta elevācijām

NYHA - N̦ujorkas sirds asociācija (New York Heart Association)

OPTIMUS - Optimizing Antiplatelet Therapy in Diabetes Mellitus

PCI - perkutāna koronāra intervence

PCR - polimerāžu ķēdes reakcija (polymerase chain reaction) 
PD - piesātinošā deva

$\mathrm{PE}$ - fikoeritrīns

PGE1 - prostaglandīns E1

P-gp - P glikoproteīns

PI3K - fosfotidilinozitol-3-kināze

PIP2 - fosfotidilinozitolbifosfăts

PKA - proteīnkināze A

PKB - proteīnkināze B

$\mathrm{PKC}$ - proteīnkināze C

PON1 - paraoksonāze 1

PRI - trombocītu reaktivitātes indekss

PSI - protonu sūkņa inhibitori

PSKUS - Paula Stradiña Klīniskā universitātes slimnīca

SD - standartdeviācija

ST - stenta tromboze

STEMI - miokarda infarkts ar ST segmenta elevācijām

$\mathrm{TF}$ - audu faktors (tissue factor)

TG - triglicerīdi

TRAP - trombīna receptoru aktivējošais peptīds

UD - uzturošā deva

VASP - vazodilatatorstimulējošais fosfoproteīns

VASP-P - vazodilatatorstimulējošā fosfoproteīna fosforilācijas pakāpe

vs - salīdzinot ar; pret (latīņu val., versus)

wt - biežāk sastopamā neizmainītas funkcijas citohroma alēle (wild-type)

ZBLH - zema blīvuma lipoproteīnu holesterīns 


\section{IEVADS}

Antiagregantu terapija ir viens no kardiovaskulārās medicīnas stūrakmeņiem. Duāla antiagregantu terapija (DAPT), ko veido aspirīns kopā ar $\mathrm{P}_{12} \mathrm{Y}_{12}$ receptoru antagonistu klopidogrelu, samazina aterotrombotisko komplikāciju risku pacientiem ar akūtu koronāru sindromu (AKS) un pēc perkutānas koronāras intervences (PCI) ar stenta implantāciju [King et al., 2008, Wijns et al., 2010]. DAPT tiek rekomendēta 12 mēnešus pēc AKS un plāna PCI gadījumā 6-12 mēnešus pēc ar zālēm pārklāta stenta (DES) implantācijas [Wijns W., 2010]. Pēdējo gadu laikā DAPT shēmās tiek izmantoti arī jaunās paaudzes $\mathrm{P}_{2} \mathrm{Y}_{12}$ receptoru antagonisti (prasugrels, tikagrelors), kuri salīdzinājumā ar klopidogrelu nodrošina ātrāku, iedarbīgāku un drošāku P2 $\mathrm{Y}_{12}$ receptoru inhibīciju [Wijns et al., 2010, Bonello et al., 2010]. Lai gan pētījumi liecina par prasugrela un tikagrelora spēju biežāk samazināt kardiovaskulārās (KV) nāves, miokarda infarkta (MI) un cerebrāla infarkta (CI) risku pacientiem ar AKS, tomēr pastāvošās šīs terapijas nepilnības kā terapijas izmaksu pieaugums un pierādījumu trūkums pacientiem pēc plānveida PCI vēl joprojām aktualizē arī klopidogrela izmantošanu [Wiviott et al., 2007, Wallentin et al., 2009]. Nav pierādīta prasugrela un tikagrelora efektivitāte pacientiem ar stabilu koronāro sirds slimību (KSS). Iepriekšminētās terapijas problēmas veicina personalizētas medicīnas meklējumus katram individuālam pacientam.

Farmakodinamiskā atbildes reakcija uz klopidogrela terapiju variē starp pacientiem un bieži vien ar standarta devām neizdodas sasniegt vēlamo trombocītu inhibīcijas pakāpi. Tās novērtēšanai ir izstrādātas vairākas trombocītu funkciju analīzes metodes ar definētiem mērķiem, piemēram, gaismas transmisijas agregometrija (LTA) maksimālā agregācija $<46 \%$ pēc adenozīna difosfāta (ADF) pievienošanas, vazodilatatorstimulējošā fosfoproteīna (VASP) fosforilācijas noteikšana - trombocìtu reaktivitātes indekss (PRI) $<50 \%$, Verify Now tests - mērķis $<235$ trombocītu reakcijas vien̄ibas [Alstrom et al., 2009, Bouman et al., 2009, Bonello et al., 2010]. VASP testu kā analīzes metodi klīnisko pētījumu veikšanai pamato sekojošas priekšrocības: (i) analīzi neietekmē citi vienlaicīgi saņemtie medikamenti (piemēram, aspirīns, glikoproteīna (GP) IIb/IIIa receptoru inhibitori), (ii) nepieciešams mazs asiņu daudzums (4ml), (iii) analizējamo paraugu līdz analīzes veikšanai var uzglabāt neatvērtu istabas temperatūrā līdz 48 stundām [Bonello et al., 2010]. 
Balstoties uz trombocītu efektivitātes funkcionālajiem testiem, hiporesponsivitāte pētījumos tiek aprakstīta līdz pat 50\% gadījumu [Gurbel et al., 2003, O'Donoghue et al., 2006, Angiolillo et al., 2004, Bonello et al., 2010], savukārt klopidogrela īsta rezistence sastopama daudz retāk no 2 līdz $11 \%$ gadījumu [Papathanasiou et al., 2007, Kim et al., 2009]. Gan veiktajos pētījumos, gan metaanalīzēs ir konstatēta samazinātas reakcijas uz klopidogrelu saistība ar KV nāves, MI un stenta trombožu (ST) biežumu pacientiem pēc PCI [Brar et al., 2011, Aradi et al., 2010].

Ir vairāki mēgeinājumi pārvarēt hiporesponsivitāti ar augstākām klopidogrela piesātinošām devām (PD) vai lielākām uzturošām devām (UD) [Hazarbasanov et al., 2012, Price et al., 2011], tomēr publicētie dati ir pretrunīgi [Bonello et al., 2008, Cuisset et al., 2008, Bonello et al., 2009, Wang et al., 2011, Aradi et al., 2012].

Tā kā līdz šim nav viennozīmīga viedokḷa par optimālu analīzes metodi trombocītu reaktivitātes mērīšanai, pastāv atšķirīgi viedokḷi par testu mērķa robežām, izvērtējot klīnisko ieguvumu un risku [Gurbel et al., 2005, Kuliczkowski et al., 2009]. Lai gan pētījumos bieži novēro VASP PRI $>50 \%$, tomēr ST incidence vērtējama kā reta ( $<1 \%$ pirmā gada laikā pēc PCI ar stenta implantāciju) [Mallouk et al., 2012, Sudhir et al., 2013]. Līdz ar to rodas jautājums, vai $\mathrm{PRI}<50 \%$ nav pārāk konservatīvs mērķis un vai nepietiktu ar PRI $<60 \%$, lai atlasītu pacientus ar klīniski nozīmīgi augstāku ST un KV notikumu risku.

Citohroma (CYP) 2C19 un ATF saistītās kasetes apakšsaimes B 1. locekḷa (ABCB1) gēnu variācijas tiek saistītas ar hiporesponsivitāti un KV notikumu biežumu pacientiem ar klopidogrela terapiju [Simon et al., 2009, Wallentin et al., 2010]. Minēto gēnu polimorfismi ietekmē klopidogrela kā prozāles metabolisma pakāpi, attiecīgi izmainot aktīvā metabolīta produkcijas apjomu un predisponējot pacientu uz sliktāku klīnisko iznākumu pēc PCI [Pettersen et al., 2011, Su et al., 2012]. Pētījumos konstatēts, ka CYP2C19 otrās alēles (CYP2C19*2) klātbūtne samazina klopidogrela farmakologisko atbildes reakciju pēc standarta devu saņemšanas, ietekmējot arī papildu devu efektivitāti [Mega et al., 2010, Bonello et al., 2012]. Savukārt CYP2C19*17 alēles nēsāšana saistīta ar paaugstinātu asiņošanas risku [Sibbing et al., 2010].

Hiporesponsivitāte pētījumos tiek saistīta ne tikai ar ǵenētisko, bet arī ar celulāro un klīnisko faktoru klātbūtni. Samazināta atbildes reakcija uz DAPT biežāk tiek novērota pacientiem ar cukura diabētu (CD) [Gurbel et al., 2007, Ferreiro et al., 2010, Hall et al., 2011], palielinātu ķermeņa masas indeksu (ĶMI) [Feher et al., 2007, 
Mallouk et al., 2012], ziņots arī par vienlaicīgi saņemto zāļu potenciālo ietekmi [Gilard et al., 2008, Harmsze et al., 2010, Kwok et al., 2012].

Literatūrā ir mēǵinājumi pārvarēt klopidogrela hiporesponsivitāti, pielietojot modificētas klopidogrela devas - atkārtotas 600 mg PD un lielākas 150 mg UD. Līdz šim ir maz pētîjumu par $C Y P 2 C 19$ un $A B C B 1$ gēnu variāciju ietekmi uz šo dozēšanas stratēgiju. Nav skaidrs, vai klopidogrela modificēto devu efektivitāte ir atkarīga no ǵenētiskajiem faktoriem un vai tās pārvarēšanas stratēgija var atšķirties atkarībā no riska alēles veida. Tātad nav izstrādāta taktika hiporesponsivitātes pārvarēšanai šo polimorfismu alēļu klātbūtnē. 


\section{DARBA HIPOTĒZES}

- Ģenētiskie un fenotipiskie faktori, kas veicina klopidogrela hiporesponsivitāti, dažādi ietekmē klopidogrela papildu PD un lielāku UD efektivitāti, tādēḷ optimālākas DAPT stratēgija var atšķirties atkarībā no iespējamā hiporesponsivitātes vai rezistences mehānisma.

- Pacientiem pēc PCI ar DES konservatīvāks PRI mērķis zem 60\% ir tikpat drošs un efektīvs kā līdz šim pieņemtais mērķis zem 50\%.

\section{DARBA MĒRĶIS}

Analizēt CYP2C19, CYP2C9 un $A B C B 1$ genētisko polimorfismu ietekmi uz papildu klopidogrela PD (600 mg) un palielinātu UD $(150$ mg $)$ efektu hiporesponsivitātes pārvarēšanai, kā arī noskaidrot augstāka PRI mērķa $(<60 \%)$ drošumu ilgtermiņā 1 gada laikā.

\section{DARBA UZDEVUMI}

1. Analizēt klopidogrela standarta PD un papildu PD efektivitātes atšksirības polimorfismu genotipu grupās (CYP2C19, CYP2C9, $A B C B 1)$.

2. Analizēt klopidogrela papildu PD stratēgijas kopējo efektivitāti.

3. Identificēt iespējamos pacientus ar īstu klopidogrela rezistenci un noskaidrot, vai jaunākās paaudzes $\mathrm{P}_{2} \mathrm{Y}_{12}$ receptoru inhibitori spēj pārvarēt hiporesponsivitāti šiem pacientiem.

4. Analizēt polimorfismu ietekmi uz palielinātu klopidogrela uzturošo dienas devu efektivitāti, salīdzinot ar standarta UD.

5. Noskaidrot fenotipisko faktoru mijiedarbību ar klopidogrela atkārtotām PD un lielāku UD.

6. Analizēt vienlaicīgi saņemtās citas medikamentozās terapijas ietekmi uz klopidogrela standarta devu un modificēto devu iedarbību.

7. Noskaidrot PRI mērķa $<60 \%$ stratēg̣ijas efektivitāti un drošumu 1 gada laikā pēc PCI ar DES. 


\section{DARBA ZINĀTNISKĀ NOVITĀTE}

Klopidogrela hiporesponsivitātes iemeslu analīzei ir ļoti liela gan zinātniska, gan praktiska nozīme. Zinātniskajā telpā ir maz informācijas par konkrētu rīcību individuālam pacientam ar samazinātu atbildes reakciju uz klopidogrela terapiju, kā arī nav apskatîta papildu devu efektivitātes atkarỉba no genotipiem. Iepriekš veiktajos pētījumos papildu devu efektivitāte tika pārbaudīta akūtiem pacientiem pēc $600 \mathrm{mg}$ klopidogrela PD saņemšanas, savukārt šajā pētijumā tika apzināta klopidogrela hiporesponsivitātes prevalence pacientiem arī pēc plāna PCI pēc 300 mg PD saņemšanas. Katram pacientam tika izstrādāta individuāla PD un UD korekcija. Vieniem un tiem pašiem pacientiem ar konstatētu klopidogrela hiporesponsivitāti tika pārbaudīta trombocītu reaktivitāte ar dažādām UD (150 mg un 75 mg). Tika analizēta genētisko faktoru ietekme uz papildu PD un dažādu UD efektu. Tika pārbaudīta arī PRI virs $60 \%$ drošība, atlasot pacientu grupu ar iespējams augstāku KV notikumu risku. 


\section{LITERATŪRAS APSKATS}

\subsection{Klopidogrela raksturojums}

Klopidogrels ir tienopiridīnu grupas antiagregants ( $\mathrm{P} 2 \mathrm{Y}_{12}$ receptoru antagonists), kas specifiski un neatgriezeniski saistās ar trombocītu $\mathrm{P}_{2} \mathrm{Y}_{12}$ purīnergískiem receptoriem, inhibējot ADF piesaistīšanos [Celik et al., 2009, Gurbel et al., 2007].

Klopidogrels ir pirmszāles, kura absorbcija notiek tievajās zarnās un aktivācija aknās. Apmēram 85 līdz 90\% no absorbētā klopidogrela daudzuma ar karboksilāžu palīdzību tiek hidrolizēts par neaktīvu karboksilskābes metabolītu. Atlikušie 10 līdz 15\% tiek metabolizēti ar aknu CYP450 izoenzīmiem par aktīvu metabolītu [Dansette et al., 2012]. Kā redzams 1.1. attēlā, primāri tiofēna gredzens klopidogela ķīmiskajā struktūrā tiek oksidēts, veidojot 2-okso-klopidogrelu, kas pēc tam tiek hidrolizēts par labīlāku aktīvo metabolītu, kas satur gan karboksilskābes, gan tiola grupas [Kazui et al., 2010, Scott et al., 2011]. Tieši tiola grupa ir tā, kas atbild par saistǐšanos pie cisteīna grupas $\mathrm{P}_{2} \mathrm{Y}_{12}$ receptoriem un par neatgriezenisku ADF blokādi. Konkrētu CYP450 enzīmu ietekmes pakāpe klopidogrela biotransformācijas procesos ir atšksirīga. Mērot enzīmu kinētiskos paramaterus, pirmajā metabolisma solī lielāka ietekme novērota CYP2C19 (44,9\%), mazāka CYP1A2 (35,8\%) un CYP2B6 (19,4\%) izoenzīmiem. Savukārt otrajā metabolisma solī CYP3A4 izoenzīms uzrāda pārliecinošāku ietekmi uz klopidogrela biotransformāciju (39,8\%), kas pamato tā inhibitoru ietekmi uz klopidogrela farmakokinētiskiem un farmakodinamiskiem procesiem [Kazui et al., 2010]. Neatgriezeniskas saistīšanās dēḷ ietekme uz zāḷu iedarbībai pakḷautiem trombocītiem saglabājas visu to atlikušo dzīves laiku (apmēram 7-10 dienas), un tādējādi normāla trombocītu darbība atjaunojas atbilstoši trombocītu atjaunošanās ātrumam. 




1.1. att. Klopidogrela metabolisms [Sangkuhl et al., 2011]

Analizējot klopidogrela darbības mehānismu (1.2. attēls), redzam, ka ADF piesaiste pie $\mathrm{G}_{\mathrm{q}} \mathrm{P} 2 \mathrm{X}_{1}$ receptora izraisa fosfolipāzes $\mathrm{C}$ (FLC) aktivāciju, kas veicina diacilglicerola (DAG) un inozitoltrifosfăta (IP3) veidošanos no fosfotidilinozitolbifosfāta (PIP2). DAG aktivē proteīnkināzi C (PKC), kas sekmē miozīnkināzes fosforilāciju (MLCK-P). IP3 izraisa intracelulārā kalcija mobilizāciju. P2Y $Y_{1}$ receptors ir saistīts arī ar otru G-proteīnu $-G_{12}$, kas aktivē proteīnus un visticamāk atbild par trombocītu formas maiṇu. ADF saistīšanās pie $\mathrm{G}_{\mathrm{i}} \mathrm{P} 2 \mathrm{Y}_{12}$ receptora atbrīvo $\mathrm{G}$ inhibējošā $\left(\mathrm{G}_{\mathrm{i}}\right)$ proteīna $\alpha_{1}$ un $\beta_{\mathrm{y}}$ daļas, kas veicina trombocītu agregācijas stabilizāciju. $\alpha_{1}$ izraisa adenilciklāzes (AC) inhibīciju, kas samazina cikliskā adenozīna monofosfāta (cAMF) līmeni un tādējādi samazina arī tā izraisīto VASP fosforilāciju. VASP atbild par GP IIb/IIIa receptoru aktivāciju. $\beta_{\mathrm{y}}$ aktivē fosfotidilinozitol-3-kināzi (PI3K), kas izraisa GP IIb/IIIa receptoru aktivāciju caur serīna-treonīna proteīnkināzi B (PKB). Prostaglandīns $\mathrm{E}_{1}\left(\mathrm{PGE}_{1}\right)$ aktivē $\mathrm{AC}$, kas paaugstina cAMP līmeni un VASP pakāpi [Angiolillo et al., 2007]. 


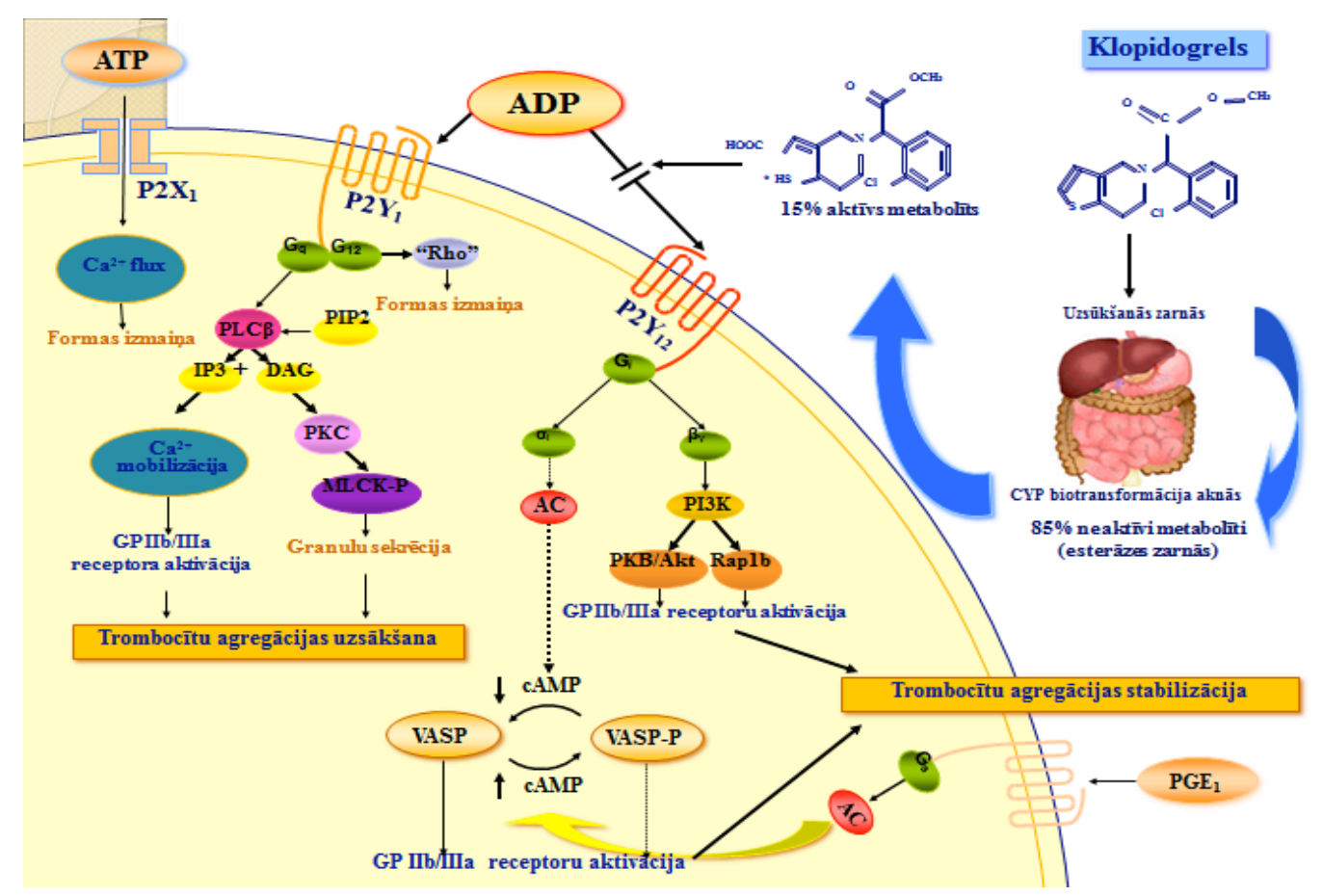

1.2. att. Klopidogrela darbības mehānisms [Angiolillo et al., 2007]

ADF - adenozīna difosfăts, FLC - fosfolipāze C, DAG - diacilglicerols, IP3 - inozitiltrifosfāts, PIP2 fosfotidilinozitolbifosfāts, PKC - proteīnkināze C, MLKC-P - miozīnkināzes fosforilācija, $\mathrm{G}_{\mathrm{i}}-\mathrm{G}$ inhibējošais proteīns, $\mathrm{AC}$ - adenilciklāze, cAMF - cikliskais adenozīna monofosfăts, VASP - vazodilatatorstimulējošais fosfoproteīns, GP - glikoproteīns, PGE1 - prostaglandīns E1, PI3K - fosfotidilinozitol-3-kināze, PKB - proteīnkināze B.

\subsection{Klopidogrela neefektivitātes definēšana}

Klopidogrela efektivitātes izmaiņas raksturo farmakodinamiskā atbildes reakcija uz antiagreganta terapiju, kura ir dažādas definīcijas. Literatūrā biežāk sastopami sekojoši apzīmējumi: "klopidogrela neefektivitāte" (nonresponsiveness, resistance) vai "neatbilstoša atbildes reakcija" (hyporesponsiveness, low responsiveness). Tomēr viedokļus vienojošais faktors ir šī fenomena skaidrojums, respektīvi, klopidogrela mērķreceptoru ( $\mathrm{P}_{12} \mathrm{Y}_{12}$ receptori uz trombocītu virsmas) paaugstināta aktivitāte atbilstošas antiagreganta terapijas laikā. Samazināta atbildes reakcija uz klopidogrelu dažādās populācijās atšķirās robežās no 2\% līdz pat 44\% [Gurbel et al., 2007, Papathanasiou et al., 2007]. Neatbilstoša antiagreganta efekta rezultātā var attīstīties išēmiskas un/vai trombemboliskas komplikācijas, no kurām kā viena no bīstamākajām ir ST [Angiolillo et al., 2007, Barone-Rochette et al., 2008, Pyrgakis et al., 2010]. 
Laboratorijas apstākḷlos klopidogrela hiporesponsivitātes un rezistences definīcija variē atkarībā no izmantotā testa esošās trombocītu reaktivitātes noteikšanai un izvēlētā testa robežvērtīibām.

\subsection{Trombocìtu funkciju testi}

Individuālu pacienta atbildes reakciju uz klopidogrela terapiju iespējams noteikt, mērot trombocītu agregāciju asins paraugā. Spēkā esošās 2011. gada Amerikas un Eiropas vadlīnijas ir piešķīušas IIb klases rekomendāciju trombocītu funkciju testiem vai genotipēšanai, ja ir iespējams terapijas rezultātu uzlabojums [Holmes et al., 2010].

Trombocītu reaktivitātes pārbaudi iespējams veikt ar vairākām metodēm, no kurām visbiežāk izmantotās ir LTA, VASP fosforilācijas noteikšana, agregometrija (piemēram, gaismas transmisijas, pretestības), VerifyNow tests.

Kā viena no pirmajām metodēm jāatzīmē LTA, kas pamatojas uz gaismas caurlaidības noteikšanu. Analīzes laikā asins plazmā tiek noteikta dažādu agonistu ietekme uz trombocītu aktivāciju (adhēziju, sekrēciju un agregāciju) in vitro. Metodes pamatprincips balstīts uz to, ka agonista ietekmē notiek trombocītu agregācija, samazinās absorbētās gaismas daudzums, pieaug gaismas caurlaidība, ko fikssē fotoelements. Optiskā blīvuma pieaugumu izskaidro ar trombocītu formas maiņu aktivācijas rezultātā. Pieejami seši agonisti, lai aktivētu trombocītus pa dažādiem aktivācijas ceḷiem: arahidonskābe, kolagēns, ADF, epinefrīns, ristocetīns un trombīna receptoru aktivējošais peptīds (TRAP), kurus atkarībā no trombocītu aktivācijas izraisītiem efektiem iedala stiprajos (kolagēns un TRAP) - vienlaikus izraisa gan tiešu trombocītu agregāciju un tromboksāna A2 sintēzi, gan trombocītu granulu sekrēciju un vājajos agonistos - neizraisa trombocītu granulu sekrēciju [Breet et al., 2010]. Šo metodi var izmantot dažādu grupu antiagregantu analīzē, katram izvēloties atbilstošu agonistu, piemēram, aspirīna terapijas efektivitātes analīzei tiek lietota arahidonskābe, P2Y12 receptoru antagonistiem - ADF, GP IIb/IIIa receptoru inhibitoriem - TRAP. Pastāvošie LTA izmantošanas ierobežojumi ir standartizācijas, sensitivitātes, jutības trūkums, darbietilpīga un laikietilpīga analizējamo paraugu sagatavošana [Breet et al., 2010, Braunwald et al., 2008, Cattaneo, 2009].

Lumiagregometrija ir nedaudz jaunākas paaudzes metode, kas mēra trombocītu agregāciju, izmantojot elektriskās vai optiskās pretestības pamatprincipus un vienlaikus nosakot arī adenozīna trifosfāta (ATF) atbrīvošanos ar luminiscences metodi. Kā agonistus biežāk izmanto trombīnu, kolagēnu un arahidonskābi. Metodes priekšrocība ir 
nepieciešamība pēc maza $(3 \mathrm{ml})$ pilnu asiņu parauga, līdz ar to šo metodi var lietot arī pediatrijā [Cattaneo, 2009, Braunwald et al., 2008].

Plateletworks metodes darbības gaitā tiek izmantots šūnu skaitītājs, nosakot trombocītu skaita atšķirību asins paraugā pirms un pēc agonista pievienošanas, pēc noteiktas formulas aprēḳinot trombocītu agregāciju vai inhibīciju procentuālā izteiksmē. Plateletworks ir salīdzinoši vienkārša metode un ir ātri veicama (rezultāts 5 minūšu laikā). Metodes trūkumi - nepieciešamas svaigas asinis (bez antikoagulanta klātbūtnes), kuras jāanalizē 10 minūšu laikā pēc parauga paṇemšanas, kā arī rezultāts ir tieši atkarīgs no precīza trombocītu skaita noteikšanas. Šo analīzes metodi lieto dažādu antiagregantu (aspirīna, P2 $\mathrm{Y}_{12}$ receptoru antagonistu, GP IIb/IIIa inhibitoru) analīzei, izmantojot atbilstošus trombocītu aktivācijas agonistus. P2 $\mathrm{Y}_{12}$ receptoru antagonistu efektivitātes precīzu analīzi ar šo metodi traucē tās rezultāta atkarība no vienlaicīgas aspirīna lietošanas [Braunwald et al., 2008, Breet et al., 2010, Williams et al., 2009].

Trombocītu funkciju analizators PFA-100 ir ātrs un precīzs trombocītu funkciju skrīninga tests, ar ko ir iespējams mērīt trombocītu adhēziju un agregāciju (primāro hemostāzi). Svarīgākie izmantošanas virzieni klīniskā praksē ir trombocītu disfunkcijas diagnostika un pacientu atbildes reakcijas uz aspirīnu noteikšana [Braunwald et al., 2008]. Analīzes laikā tiek izmantotas mazas membrānas, kas ir pārklātas ar kolagēnu / epinefrīnu vai ar kolagēnu / ADF. Antikoagulēts (ar citrātu) pilnu asiņu paraugs šķērso šīs membrānas ar ătrumu, kas ir identisks in vivo hemodinamikai mazajos kapilāros. Trombocīti pielīp pie membrānām, pakāpeniski nosprostojot šauro atvērumu katras membrānas centrā. Tiek mērīts laiks (sekundēs) līdz piln̄̄gai asins plūsmas pārtraukšanai. Iemesls divu membrānu izmantošanai ir atšķirības starp medikamentu izraisītiem un citiem trombocītu defektiem. Kolagēna / epinefrīna membrāna, salīdzinot ar kolagēna / ADF membrānu, ir jutīgāka uz visiem trombocītu funkciju traucējumiem, ieskaitot arī aspirīna izraisītu trombocītu disfunkciju [Breet et al., 2010]. No šī testa priekšrocībām var minēt analīzes ātro un vienkāršo gaitu ar nepieciešamiem maziem pilnu asiņu paraugiem, kā arī nav nepieciešama iepriekšēja speciāla sagatave. No trūkumiem jāatzīmē metodes atkarība no fon Villebranda faktora, trombocītu skaita un hematokrīta līmeņa. Šo testu nevar izmantot $\mathrm{P} 2 \mathrm{Y}_{12}$ receptoru antagonistu efektivitātes analīzei [Breet et al., 2010, Chang et al., 2009, Hayward et al., 2006].

Multielektrodu agregometrija (MEA) balstās uz divkāršu pretestības agregometrijas mērī̌sanu ar Multiplate analizatoru pilnu asiņu paraugā pēc trombocītu stimulācijas ar ADF atseviški vai kopā ar PGE1. No metodes priekšrocībām jāmin 
analīzes veikšanas ātrums (vidēji 10 minūtes), mazs nepieciešamais parauga tilpums $(0,3 \mathrm{ml})$, datorkontrolēta elektroniskā reağentu pievienošana, aspirīna (agonists arahidonskābe), $\mathrm{P} 2 \mathrm{Y}_{12}$ receptoru antagonistu (agonists - ADF) un citu antiagregantu analīzes augstā jutība (piemēram, analizējot GP IIb/IIIa inhibitorus, kā agonistu biežāk izmantojot TRAP), kā arī spēja identificēt trombocītu samazinātas vai pastiprinātas agregācijas spējas [Morris et al., 2009, Williams et al., 2009].

VerifyNow ir viens no visbiežāk izmantotajiem trombocītu funkcionālajiem testiem pēdējo gadu pētījumos. To var skaidrot ar šīs metodes vienkāršību, tā ir ātri izpildāma (rezultāts 5 minūšu laikā) un neprasa padziļinātu personāla apmācību, kā arī nav nepieciešama asins parauga sagatavošana. Šì metode balstās uz optiskās agregometrijas principiem. Metodes pamatā ir trombocītu funkciju analīze pilnu asiņu paraugā, nosakot gaismas caurlaid̄̄bas ātruma un pakāpes maiņu trombocītu agregācijas rezultātā. Šīs pārmaiṇas attīstās kā atbildes reakcija uz specifisku agonistu pievienošanu (arahidonskābe - aspirīna terapijas analīzei, ADF - P2Y12 receptoru antagonistu, TRAP - GP IIb/IIIa inhibitoru terapijas analīzei). Asins paraugā ar samazinātu trombocītu agregācijas spēju konstatē zemu gaismas caurlaidību, savukārt asins paraugos ar normālām trombocītu funkcijām - augstu gaismas caurlaidības pakāpi. To var izmantot dažādu grupu antiagregantu terapijas analīzei. VerifyNow metodei ir būtisks trūkums, kas liedz ar to adekvāti izvērtēt klopidogrela un aspirīna terapijas efektu pacientiem, kuri pēdējo 48 stundu laikā saņēmuši GP IIb/IIIa receptoru antagonistus (piemēram, tirofibāns, eptifibatīds) vai pēdējo 14 dienu laikā abciksimabu. Tā kā fibrinogēna saistīšanās pie GP IIb/IIIa receptoriem ir pēdējais agregācijas posms, šo receptoru antagonistu klātbūtne var izraisīt mijiedarbību ar klopidogrela un aspirīna analīzei paredzēto analīzes reaǵentu sastāvu [Williams et al., 2009, Morris et al., 2009, Breet et al., 2010].

Plūsmas citometrija ir specifiska trombocītu funkciju analīzes metode P2 $\mathrm{Y}_{12}$ receptora antagonistu - t. s. tienopiridīnu grupas antiagregantu - efektivitātes izvērtēšanai. Šī metode mēra fizikālas vai kīmiskas pazīmes, kas raksturīgas šūnām un notiek brīdī, kad lineāra šūnu plūsma škēerso lāzergaismas staru kūli. Būtībā tiek skenēta katra šūna, kas plūst garām analizatoriem. Metode piedāvā arī šūnu škirirošanu, izmantojot elektriskās vai mehāniskās vērtības, lai šūnas sakopotu izvēlēta darbības lauka robežās. Līdz ar to plūsmas citometriju bieži izmanto individuālu šūnu raksturošanai un atdalīšanai. Metode balstās uz gaismas izkliedes un fluorescences intensitātes noteikšanu fluorescējošām iezīmētām antivielām vai ligandiem, kas specifiski saistās pie šūnas molekulām, mērot redzamu un fluorescējošu gaismas emisiju. Minētā metode ḷauj veikt ātru, kvantitatīivu multiparametru analīzi. 
Viena no plūsmas citometrijas metodēm ir VASP fosforilācijas mērīšana, kas atspoguḷo intracelulārā signāla maiņu. Tā raksturo trombocītu aktivācijas specifisku ceḷu caur $\mathrm{P}_{12} \mathrm{Y}_{12}$ receptoriem, kurus inhibē klopidogrels un citi $\mathrm{P}_{2} \mathrm{Y}_{12}$ receptora antagonisti, līdz ar to iespējams analizēt specifisku trombocītu agregāciju [Kuliczkowski et al., 2009]. No priekšrocībām jāmin mazs parauga tilpums un iespēja analīzei izmantot pilnu asiņu paraugu. Būtiskākie trūkumi ir laikietilpīga parauga sagatavošana un nepieciešamība padziļināti apmācīt personālu [Oestreich et al., 2009].

Ar plūsmas citometriju trombocītu virsmas marķieros var noteikt izmaiņas, kas atkarīgas no aktivācijas. Pie šādām metodēm pieder trombocītu virsmas P-selektīna, aktivēto GP IIb/IIIa un leikocītu un trombocītu agregācijas mērīšana. Kā priekšrocības var minēt analīzēm nepieciešamus mazus parauga tilpumus, analizējot pilnas asinis; būtiskākie trūkumi - sarežğìts parauga sagatavošanas process, nepieciešams apmācīts personāls, ierobežota izmantošana citu grupu antiagregantu terapijas efektivitātes izvērtēšanā [Oestreich et al., 2009].

Biežāk izmantoto testu raksturojums un izmantošanas iespēju apkopojums 1.1. tabulā.

Trombocītu funkciju analīzei izmantojamo testu raksturojums

[Braunwald et al., 2008, von Beckerath et al., 2009, Morris et al., 2009]

\begin{tabular}{|c|c|c|c|c|c|}
\hline \multirow[t]{2}{*}{ Tests } & \multirow[t]{2}{*}{ Priekšrocības } & \multirow[t]{2}{*}{ Trūkumi } & \multicolumn{3}{|c|}{$\begin{array}{l}\text { Izmantošanas iespējas medikamentu } \\
\text { analīzē }\end{array}$} \\
\hline & & & Aspirīns & $\begin{array}{l}\mathrm{P} 2 \mathrm{Y}_{12} \\
\text { receptoru } \\
\text { antagonisti }\end{array}$ & $\begin{array}{l}\text { GP } \\
\text { IIb/IIIa } \\
\text { inhibitori }\end{array}$ \\
\hline $\begin{array}{l}\text { Gaismas } \\
\text { transmisijas } \\
\text { agregometrija }\end{array}$ & $\begin{array}{l}\text { Izmanto pilnu } \\
\text { asinu paraugu. }\end{array}$ & $\begin{array}{l}\text { Nepieciešams } \\
\text { liels parauga } \\
\text { tilpums, } \\
\text { laikietilpīga } \\
\text { parauga } \\
\text { sagatavošana. }\end{array}$ & $\overline{J a ̄}$ & $\mathrm{Jā}$ & $\mathrm{Ne \overline {C }}$ \\
\hline
\end{tabular}


1.1.tabulas turpinājums

\begin{tabular}{|c|c|c|c|c|c|}
\hline \multirow[t]{2}{*}{ Tests } & \multirow[t]{2}{*}{ Priekšrocības } & \multirow[t]{2}{*}{ Trūkumi } & \multicolumn{3}{|c|}{$\begin{array}{l}\text { Izmantošanas iespējas medikamentu } \\
\text { analīzē }\end{array}$} \\
\hline & & & Aspirīns & $\begin{array}{l}\mathrm{P} 2 \mathrm{Y}_{12} \\
\text { receptoru } \\
\text { antagonisti }\end{array}$ & $\begin{array}{l}\text { GP } \\
\text { IIb/IIIa } \\
\text { inhibitori }\end{array}$ \\
\hline $\begin{array}{l}\text { Pretestības } \\
\text { agregometrija } \\
\text { Lumiagrego- } \\
\text { metrija }\end{array}$ & $\begin{array}{l}\text { Izmanto pilnu } \\
\text { asingu paraugu. }\end{array}$ & $\begin{array}{l}\text { Lielas izmaksas, } \\
\text { nepieciešams } \\
\text { liels parauga } \\
\text { tilpums, } \\
\text { laikietilpīga } \\
\text { parauga } \\
\text { sagatavošana. }\end{array}$ & $\mathrm{Ja} \overline{\mathrm{a}}$ & Jā & $\mathrm{Jā}$ \\
\hline VerifyNow & $\begin{array}{l}\text { Izmanto pilnu } \\
\text { asinu paraugu, } \\
\text { vienkāršs, ātrs, } \\
\text { mazs parauga } \\
\text { tilpums, nav } \\
\text { vajadzīga } \\
\text { parauga } \\
\text { sagatavošana, } \\
\text { automātiska } \\
\text { parauga } \\
\text { analīze. }\end{array}$ & $\begin{array}{l}\text { Nav iespējama } \\
\text { instrumentāla } \\
\text { pielāgošana. }\end{array}$ & $\mathrm{Ja}$ & $\mathrm{Ja}$ & $\overline{J a ̄}$ \\
\hline PFA-100 & $\begin{array}{l}\text { Vienkāršs, } \\
\text { nepieciešams } \\
\text { pilnu asiņu } \\
\text { paraugs, ātrs, } \\
\text { nav } \\
\text { nepieciešama } \\
\text { parauga } \\
\text { sagatavošana. }\end{array}$ & $\begin{array}{l}\text { Rezultāts } \\
\text { atkarīgs no von } \\
\text { Willebranda } \\
\text { faktora un } \\
\text { hematokrīta } \\
\text { limmenna. }\end{array}$ & Jā & $\begin{array}{l}\text { Nav ieteicams/ } \\
\text { zināms }\end{array}$ & $\begin{array}{l}\text { Nav } \\
\text { ieteicams/ } \\
\text { zināms }\end{array}$ \\
\hline $\begin{array}{l}\text { Plūsmas } \\
\text { citometrija } \\
\text { Trombocītu } \\
\text { virsmas P- } \\
\text { selektīna, } \\
\text { aktivētā GP } \\
\text { IIb/IIIa, } \\
\text { leikocītu - } \\
\text { trombocītu } \\
\text { agregātu } \\
\text { noteikšana. }\end{array}$ & $\begin{array}{l}\text { Izmanto pilnu } \\
\text { asinuu paraugu; } \\
\text { Nepieciešams } \\
\text { mazs parauga } \\
\text { tilpums. }\end{array}$ & $\begin{array}{l}\text { Nepieciešama } \\
\text { parauga } \\
\text { sagatavošana; } \\
\text { Vajadzīgs } \\
\text { plūsmas } \\
\text { citometrs un } \\
\text { apmācīts } \\
\text { personāls } \\
\text { analīzes } \\
\text { veikšanai. }\end{array}$ & $\mathrm{Ja}$ & $\mathrm{Jā}$ & $\mathrm{Jā}$ \\
\hline $\begin{array}{l}\text { VASP } \\
\text { fosforilācijas } \\
\text { analīze. }\end{array}$ & & & $\mathrm{Ne \overline { }}$ & $\mathrm{Jā}$ & $\mathrm{Ne}$ \\
\hline
\end{tabular}


1.1.tabulas nobeigums

\begin{tabular}{|c|c|c|c|c|c|}
\hline \multirow[t]{2}{*}{ Tests } & \multirow[t]{2}{*}{ Priekšrocības } & \multirow[t]{2}{*}{ Trūkumi } & \multicolumn{3}{|c|}{$\begin{array}{l}\text { Izmantošanas iespējas medikamentu } \\
\text { analīzē }\end{array}$} \\
\hline & & & Aspirīns & $\begin{array}{l}\mathrm{P} 2 \mathrm{Y}_{12} \\
\text { receptoru } \\
\text { antagonisti }\end{array}$ & $\begin{array}{l}\text { GP } \\
\text { IIb/IIIa } \\
\text { inhibitori }\end{array}$ \\
\hline $\begin{array}{l}\text { Multielektrodu } \\
\text { agregometrija } \\
\text { (MEA) }\end{array}$ & $\begin{array}{l}\text { Izmanto pilnu } \\
\text { asiņu paraugu, } \\
\text { vienkāršs, âtrs, } \\
\text { nav } \\
\text { nepieciešama } \\
\text { parauga } \\
\text { sagatavošana. }\end{array}$ & $\begin{array}{l}\text { Manuāla } \\
\text { pipetēšana un } \\
\text { reaǵentu } \\
\text { sagatavošana, } \\
\text { kam ir īss } \\
\text { izmantošanas } \\
\text { laiks. }\end{array}$ & $\mathrm{Ja} \overline{\mathrm{a}}$ & Jā & $\mathrm{Jā}$ \\
\hline $\begin{array}{l}\text { Tromboelasto- } \\
\text { gramma }\end{array}$ & $\begin{array}{l}\text { Izmanto pilnu } \\
\text { asiņu paraugu, } \\
\text { mazs parauga } \\
\text { tilpums, nav } \\
\text { nepieciešama } \\
\text { parauga } \\
\text { sagatavošana. }\end{array}$ & $\begin{array}{l}\text { Informācijas } \\
\text { trūkums sakarā } \\
\text { ar ierobežotu } \\
\text { izmantošanu. }\end{array}$ & $\mathrm{Ja} \overline{\mathrm{a}}$ & $\mathrm{Jā}$ & $\mathrm{Ja}$ \\
\hline Impact-R & $\begin{array}{l}\text { Izmanto pilnu } \\
\text { asiņu paraugu, } \\
\text { mazs parauga } \\
\text { tilpums, nav } \\
\text { nepieciešama } \\
\text { parauga } \\
\text { sagatavošana. }\end{array}$ & $\begin{array}{l}\text { Informācijas } \\
\text { trūkums sakarā } \\
\text { ar ierobežotu } \\
\text { izmantošanu. }\end{array}$ & $\mathrm{Jā}$ & Jā & $\begin{array}{l}\text { Nav } \\
\text { ieteicams/ } \\
\text { zināms }\end{array}$ \\
\hline
\end{tabular}

\subsection{Klopidogrela efektivitātes variabilitāti ietekmējošie faktori}

\subsubsection{Genētiskie faktori}

Pēdējo gadu zinātniskos pētījumos aprakstīta genētisko faktoru saistība ar novēroto atbildes reakcijas variabilitāti uz klopidogrela terapiju. Tiek ziņots par kandidātgēnu ietekmi gan uz klopidogrela metabolismu aknās, gan uz sagaidāmo efektivitāti. Bieži ziņojumos tiek analizēti CYP450 izoenzīmu [Shuldiner et al., 2009, Simon et al., 2009], kā arī ar ATF saistītās kasetes apakšsaimes B 1. locekḷa ( $A B C B 1$ (ATP-binding cassette sub-family B member 1), pazīstams arī kā MDR1 - multizāļu rezistences proteīns 1 (Multidrug resistance protein 1) kodējošā gēna polimorfismi [Wallentin et al., 2010, Su et al., 2012]. Pacientiem, kuri saņem klopidogrela terapiju pēc AKS un / vai stenta implantācijas, ar jebkuru CYP2C19 izoenzīma samazinātas 
funkcijas alēli $(* 2, * 3, * 4, * 5, * 6, * 7$ un *8) ir novērots paaugstināts risks išēmisko notikumu un ST attīstībai [Mega et al., 2009, Shuldiner et al., 2009, Hulot et al., 2010], savukārt šî izoenzīma pastiprinātas funkcijas alēles (*17) nēsātājiem pieaug asiņošanas attīstības iespēja [Sibbing et al., 2010]. Polimorfismi gēnos, kas atbild par klopidogrela absorbciju un izvadīšanu no organisma, piemēram, gēnā, kas kodē P-glikoproteīna (Pgp) $M D R 1$ transportieri, var ietekmēt nelabvēlīgo KV notikumu skaitu klopidogrela terapijas laikā [Simon et al., 2009].

\section{CYP450 enzīmu polimorfismi}

Klopidogrelam kā pirmszālēm nepieciešama absorbcija tievajās zarnās un biotransformācija par aktīvo metabolītu ar CYP450 enzīmiem [Dansette et al., 2012]. Daudzos pētījumos samazinātas funkcijas genētiskais variants CYP2C19 gēnā, kas atrodas 10. hromosomā, saistās ar zemāku aktīvā metabolīta līmeni, samazinātu trombocītu inhibīciju un augstāku risku KV notikumu attīstībai klopidogrela terapijas laikā [Shuldiner et al., 2009, Giusti et al., 2009]. Balstoties uz ǵenētisko polimorfismu starp biežāk sastopamiem CYP2C19 genotipiem (CYP2C19*2 un CYP2C19*3), tiek izdalīti trīs fenotipi: vājais, vidējais un normālais metabolizētājs. Šo genotipu samazinātas funkcijas alēlu prevalence starp dažādām etniskām grupām apkopota 1.2. tabulā.

1.2. tabula

\section{CYP450 samazinātas funkcijas alēḷu prevalence etnisko grupu ietvaros}

[Beitelshees et al., 2011]

\begin{tabular}{|l|l|l|l|l|}
\hline Rase & $\begin{array}{l}* 2 \text { alēles } \\
\text { frekvence }\end{array}$ & $\begin{array}{l}\text { *3 alēles } \\
\text { frekvence }\end{array}$ & $\begin{array}{l}\text { Vidējie } \\
\text { metabolizētāji } \\
\text { (\%) }\end{array}$ & $\begin{array}{l}\text { Vājie } \\
\text { metabolizētāji } \\
\text { (\%) }\end{array}$ \\
\hline Eiropieši & 0,14 & 0,00 & 24 & 2 \\
\hline Aziāti & 0,27 & 0,09 & 46 & 10 \\
\hline Afrikānni & 0,14 & 0,00 & 24 & 2 \\
\hline $\begin{array}{l}\text { Afrikāņu } \\
\text { izcelsmes } \\
\text { amerikāņi }\end{array}$ & 0,18 & 0,008 & 30 & 3,5 \\
\hline
\end{tabular}

Vidējie metabolizētāji $-* 1 / * 2$ un *1/*3, vājie metabolizētāji $-* 2 / * 2, * 3 / * 3$ un *2/*3.

Tā kā CYP2C19*2 alēle sastopama biežāk nekā $C Y P 2 C 19 * 3$, līdz ar to arī pieejami plašāki pētījumu dati par š̄is alēles saistību ar samazinātu klopidogrela efektivitāti, līdz ar to palielinātu MI un ST attīstības risku [Momary et al., 2010]. Divās meta analīzēs pacientiem ar CYP2C19*2 novēroja augstāku KV notikumu risku, 
salīdzinot ar *1/*1 genotipu [Mega et al., 2010, Sofi et al., 2010]. Mega et al. pētījumā no 162 veseliem brīvprātīgiem, kuri saṇēma klopidogrela terapiju, apmēram 30\% bija vismaz vienas samazinātās funkcijas alēles nēsātāji, kuriem novēroja klopidogrela aktīvā metabolīta redukciju plazmā par 32,4\%, salīdzinot ar pacientiem bez samazinātas funkcijas alēlēm [Mega et al., 2009]. Arī TRITON-TIMI 38 (Prasugrel Compared with Clopidogrel in Patients Undergoing Percutaneous Coronary Intervention for STElevation Myocardial Infarction) pētījumā iekḷautiem pacientiem nelabvēlīgie klīniskie iznākumi (KV nāve, MI, CI) biežāk tika novēroti tiem, kuri bija CYP2C19*2 alēles nēsātāji [Wiviott et al., 2008].

Arī Shuldiner et al. pētījumā, kur tika analizēta CYP2C19*2 genotipa ietekme uz trombocītu funkciju un ilgterminga KV notikumiem pacientiem pēc PCI, pacientiem ar CYP2C19*2 genotipu biežāk novēroja samazinātu atbildes reakciju uz klopidogrela terapiju. Pacientiem ar š̄ genotipa samazinātas funkcijas alēli viena gada novērojumā biežāk tika reǵistēti išēmiski notikumi un nāves gadījumi (HR 2,42; 95\% CI, 1,18-4,99; $\mathrm{p}=0,02)$ [Shuldiner et al., 2009].

Jāpiebilst, ka divos lielos retropsektīvos pētījumos kā CURE (Clopidogrel in Unstable Angina to Prevent Recurrent Events) [Pare et al., 2010] un PLATO (Platelet Inhibition and Patient Outcomes) [Wallentin et al., 2010] š̄ asociācija starp CYP2C19 genotipu un KV notikumiem netika novērota.

Simon et al.pētījumā novēroja, ka jebkuru divu CYP2C19 samazinātas funkcijas alēļu (*2, *3, *4 vai *5) nēsātājiem ir augstāks KV notikumu risks [Simon et al., 2009].

ELEVATE-TIMI 56 (Escalating Clopidogrel by Involving a Genetic Strategy Thrombolysis in MI 56) multicentru, randomizētā, dubultaklā pētījumā analizēja, vai palielināta klopidogrela UD (līdz $300 \mathrm{mg} /$ dienā) spēj izmainīt trombocītu reaktivitāti pacientiem ar CYP2C19*2 samazinātas funkcijas alēli, nosakot atšķirību starp heterozigotiem, kas sastāda apmēram $25-45 \%$ no populācijas atkarībā no rases, un homozigotiem. Tika izvirzītas hipotēzes, ka palielinot UD pacientiem ar CYP2C19*2 attiecīgi samazināsies trombocītu reaktivitāte un ka augstāka UD šiem pacientiem būs tikpat efektīva kā klopidogrela standarta UD (75 mg / dienā) pacientiem bez šīs alēles. Pētījumā konstatēja, ka gan heterozigotiem, gan homozigotiem ar šo samazinātās funkcijas alēli $(C Y P 2 C 19 * 2)$ bija paaugstināta trombocītu reaktivitāte, ko nenovēroja pacientiem bez šīs alēles, attiecīgi vidējais VASP PRI bija 70,0\% un 86,6\% pret 57,5\%, $\mathrm{p}<0.001$ (skat. 1.3. tabulu). Uzturošās devas pieaugums par katriem $75 \mathrm{mg}$ samazināja PRI vidēji par 8-9\% no absolūtās vērtības. 
Trombocītu reaktivitāte atkarībā no genotipa un klopidogrela uzturošās devas

[Mega et al., 2011]

\begin{tabular}{llllll}
\hline Genotips & $\mathbf{7 5} \mathbf{~ m g}$ & $\mathbf{1 5 0} \mathbf{~ m g}$ & $\mathbf{2 2 5} \mathbf{~ m g}$ & $\mathbf{3 0 0} \mathbf{~ m g}$ & $\mathbf{p}$ \\
\hline CYP2C19*1/*1 & 57,5 & 46,9 & - & - & $<0,001$ \\
CYP2C19*1/*2 & 70,0 & 61,4 & 52,7 & 48,9 & $<0,001$ \\
CYP2C19*2/*2 & 86.6 & 77.8 & 73.0 & 68.3 & 0.003 \\
\hline
\end{tabular}

Paaugstinātas UD starp heterozigotiem samazināja pacientu skaitu, kuriem sākumā šī terapija nebija pietiekami efektīva. Bet pacientiem ar CYP2C19*2/*2 (homozigotiem) arī ar 300 mg / dienā UD vidējais VASP PRI saglabājās 68,3\% [Mega et al., 2011].

Citā pētîjumā, salīdzinot palielinātas UD (150 mg / dienā) efektivitāti pacientiem ar CYP2C19*2 un bez tās, novēroja, ka š̄ uzturošā deva bija efektīva tikai 28\% pacientu ar samazinātas funkcijas alēli, salīdzinot ar pacientiem bez šīs alēles, kam šî stratēǵija pierādīja efektivitāti 50\% gadījumu. Pētījuma rezultāti liecināja, ka samazinātas funkcijas alēles nēsātājiem iespējams vajadzētu izvēlēties citu P2 $\mathrm{Y}_{12}$ receptoru antagonistu terapiju [Cuisset et al., 2011]. Pretēji Simon et al. veiktajā pētījumā iegūtie rezultāti norādīja, ka klopidogrela hiporesponsivitāti pacientiem ar vismaz vienu CYP2C19 samazinātas fnkcijas alēli tomēr izdodas pārvarēt, izmantojot lielāku PD (600 mg) un lielāku UD (150 mg / dienā) [Simon et al., 2011].

Brandt et al. veiktā pētījuma dati apliecina arī CYP2C9 izoenzīma asociāciju ar klopidogrela aktīvā metabolīta koncentrāciju [Brandt et al., 2007]. CYP2C9*2 un *3 samazinātas funkcijas alēlu nēsātājiem novērota pazemināta antiagregantu efektivitāte [Cavallari et al., 2011]. Pretrunīga informācija sastopama arī par CYP3A4 ietekmi uz klopidogrela metabolismu [Polena et al., 2008].

CYP2C19*17 alēles variants saistîts ar palielinātu funkcionālo aktivitāti, kas paātrina CYP2C19 substrātu metabolismu, tādējādi nodrošinot augstāku klopidogrela koncentrāciju un lielāku trombocītu inhibīciju. Sibbig et al. veiktajā pētījumā, analizējot 1524 pacientus pēc PCI, kas pirms procedūras bija saṇēmuši klopidogrela 600 mg PD, konstatēja atšksirīgu risku pacientiem ar CYP2C19*17 alēles variantiem. CYP2C19*17 alēles nēsātājiem, īpaši homozigotiem, konstatēja statistiski ticamu saistību ar trombocītu agregācijas samazinājumu $(\mathrm{p}<0,001)$, kas liecina par palielinātu atbildes 
reakciju uz klopidogrela terapiju, kā arī paaugstinātu asiņošanas risku $(p=0,006)$ [Sibbing et al., 2010]. Bet ņemot vērā to, ka klopidogrela efektivitāti ietekmē arī fenotipiskie un celulārie faktori, joprojām nav viennozīmīga viedokḷa par genētisko testu veikšanas lietderību ikdienas praksē [Goswami et al., 2012].

Pārējo klopidogrela metabolismā iesaistīto CYP450 izoenzīmu (CYP1A2, CYP2B6, CYP3A5) ietekmei nav novērota asociācija ar klīniski apstiprinātu risku nelabvēlīgu KV notikumu attīstībai [Kirchheiner et al., 2005, Brandt et al., 2007, Ancrenaz et al., 2010, Mega et al., 2009].

\section{MDR1 (ABCB1) gēna polimorfismi}

Viens no citiem proteīniem, kas iesaistīts tienopiridīnu grupas zāḷu līdzekḷlu absorbcijāa, ir P-gp, kuru kodē $A B C B 1$ gēns (pazīstams arī kā MDRl), kas atrodas 7. hromosomā. P-gp ir ATF atkarīgs transporta sūknis daudzu vielu molekulām starp ekstra- un intracelulārām membrānām. Daļa no P-gp izvietota arī tievo zarnu epitēlijšūnās, kur palielināta š̄ transportproteīna ekspresija vai funkcija veicina zāḷu, kas ir kā substrāti, biopieejamību. Pētījumos iegūtie dati liecina, ka klopidogrela terapijas laikā $A B C B 1$ TT homozigotiem novēro zemāku klopidogrela aktīvā metabolīta koncentrāciju, līdz ar to augstāku risku nelabvēlīgo klīnisko iznākumu attīstībai [Simon et al., 2009, Taubert et al., 2006]. Arī TRITON-TIMI 38 pētījumā TT ǵenētiskais variants uzrādīja asociāciju ar augstāku KV notikumu risku, salīdzinot ar CC homozigotiem (skat. 1.3. attēlu) [Mega et al., 2010]. Tomēr citos lielos pētījumos (piemēram, PLATO) dati par š̄ genotipa asociāciju bija pretrunīgi [Wallentin et al., 2010]. 


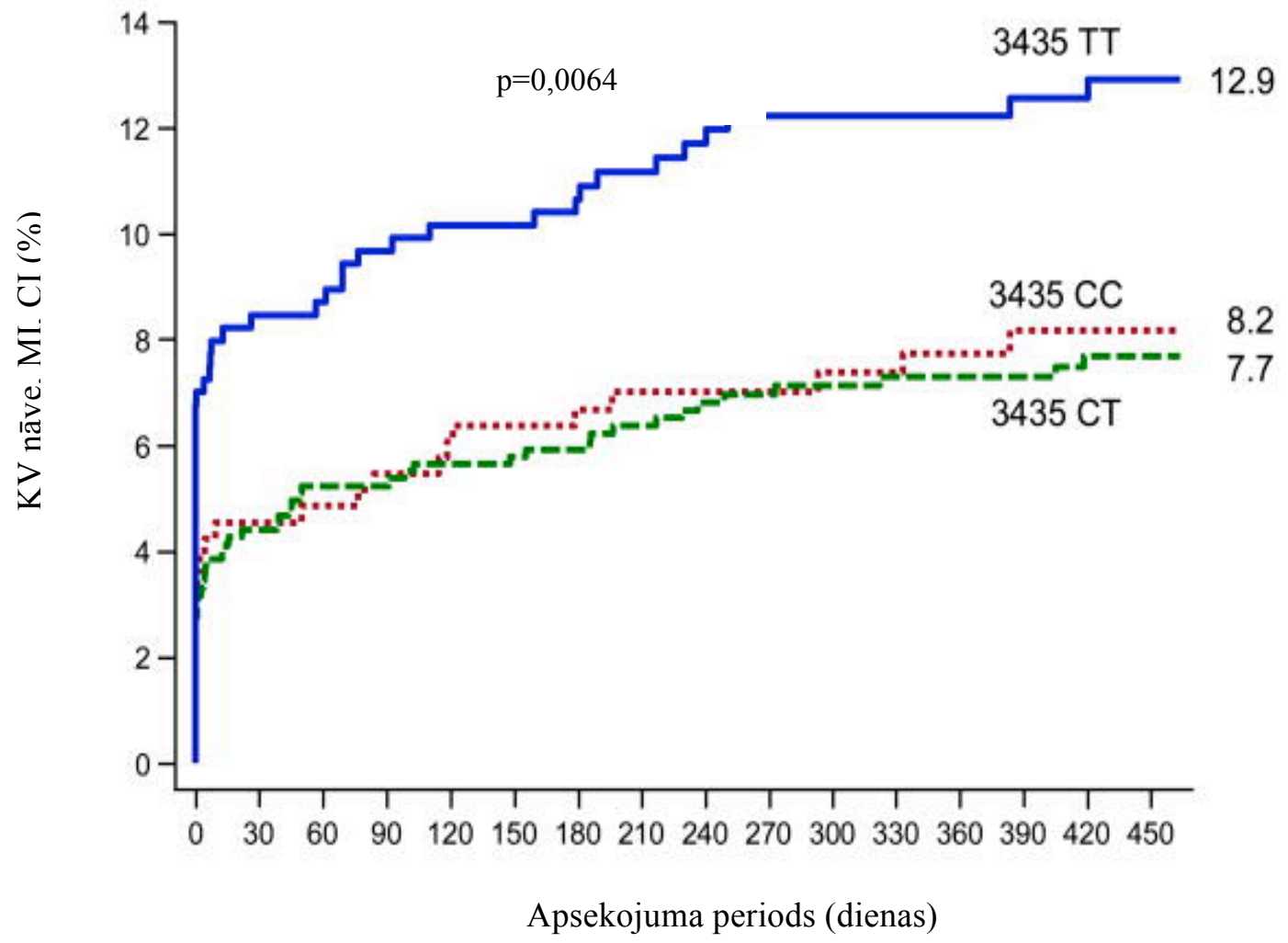

\section{3.att. ABCB1 polimorfisma ietekme uz KV notikumu attīstību}

[Jessica L. Mega, 2010]

\section{Paraoksonāzes (PON) 1 polimorfisms}

Šī enzīma polimorfismi arī raksturojas ar pretrunīgu informāciju. Bieži vien š̄̄ enzīma ietekme tiek saistīta ar vienlaicīgu CYP2C19 samazinātas funkcijas alēlu klātbūtni [Nishio et al., 2013], bet atsevišksi š̄ enzīma polimorfismi neietekmē klopidogrela farmakokinētiskos un farmakodinamiskos parametrus [Braun et al., 2013]. Gan GIFT (Genotype Information and Functional Testing Study), gan GRAVITAS (Gauging Responsiveness with A VerifyNow assay - Impact on Thrombosis And Safety) pētījumos netika novērota $P O N 1$ polimorfisma ietekme arī uz paaugstinātu klopidogrela UD pacientiem pēc PCI [Price et al., 2011, Price et al., 2012]. 


\section{GPIIIa (PIA1/PIA2) polimorfisms}

Dažos mazos pētījumos ziņots par klopidogrela antiagregatīvā efekta samazinājumu saistībā ar GPIIIa PlA2 alēli. Pētījumā tika konstatēts, ka $600 \mathrm{mg}$ klopidogrela PD biežāk nenodrošina nepieciešamo trombocītu inhibīcijas pakāpi šī polimorfisma pacientiem ar stabilu koronāro artēriju slimību, kuriem paredzēta plāna PCI. Pacientiem PIA2 nēsātājiem bija novērota tendence uz samazinātu atbildes reakciju uz klopidogrela terapiju (PRI> 50\%), salīdzinot ar PIAl/PIAl genotipu (54 vs 24\%, $\mathrm{p}=0,082$ ) [Motovska et al., 2009]. Lai gan iepriekš šis polimorfisms biežāk tika minēts kā aspirīna rezistences cēlonis, nesen publicētā meta-analīze neapstiprināja asociāciju starp PIA2 alēli un klopidogrela rezistenci [Floyd et al., 2013].

\section{$\mathrm{P}_{\mathrm{R}} \mathrm{Y}_{12}$ receptora polimorfismi}

Šis G1 receptors ar ekstracelulāri novietoto cisteīnu ir atbildīgs par trombocītu agregācijas piln̄̄gu izpildi kā atbildes reakciju uz ADF, kam seko citu signālmolekulu aktivācija, piemēram, cAMF, VASP defosforilācija. Farmakoloǵiskie pētījumi liecina par š̄i receptora lomu arī fibrinogēna receptoru aktivācijā, P-selektīna ekspresijā un trombu veidošanas procesā. $\mathrm{P} 2 \mathrm{Y}_{12}$ nozīmi pastiprina fakts, ka tas ir tienopiridīnu grupas zāḷu līdzekḷu darbības mērķis [Wang et al., 2006]. Nesen veiktajā pētîjumā P2 $Y_{12}$ gēna viena nukleotīda polimorfisms $(18 \mathrm{C}>\mathrm{T})$ uzrādīja ietekmi uz klopidogrela terapijas farmakologisko atbildes reakciju, respektīvi, vairāk pacientu ar šo polimorfismu bija grupā ar hiporesponsivitāti [Galic et al., 2013]. Tomēr vēl joprojām ir nepieciešami lielāki prospektīvi klīniski pētījumi šī polimorfisma ietekmes apstiprināšanai.

\subsubsection{Celulārie faktori}

Klopidogrela darbības pamatā ir neatgriezenisks antagonisms ar trombocītu $\mathrm{P}_{2} \mathrm{RY}_{12}$ ADF receptoriem. Klopidogrela rezistences gadījumā pieaug trombocītu atbildes reakcijas variabilitāte uz ADF. Michelson et al. pētījumā tika izvirzīta hipotēze, ka klopidogrela rezistences fenomenu izraisa jau pirms klopidogrela terapijas uzsākšanas pastāvošā trombocītu atbildes reakcija uz ADF, kura nepieaug klopidogrela terapijas laikā. Pētījumā iegūtie rezultāti mudina domāt, ka dažiem pacientiem klopidogrela rezistence var būt saistīta ar jau iepriekš novērotas trombocītu atbildes reakcijas uz ADF variabilitāti un nav vērojamas būtiskas izmaiṇas pēc klopidogrela 
lietošanas uzsākšanas [Michelson et al., 2007]. Hronisks iekaisums var izraisīt endotēlija bojājumu, veicinot fiziologisko antikoagulantu, antiagregantu un vazodilatatoro īpašî̉bu zudumu. Līdz ar to samazināta atbildes reakcija uz klopidogrela terapiju iespējama pacientiem ar iekaisuma slimībām (piemēram, reimatoīdo artrītu), kas var veicināt antiagreganta rezistenci [Aksu et al., 2012, Bonello et al., 2010].

\subsubsection{Klīniskie faktori}

Kā trešā grupa ar ietekmi uz klopidogrela terapiju ir pacienta demogrāfiskie un klīniskie faktori, piemēram, vecums (>55 gadiem), smēksēšana [Gremmel et al., 2009], palielināts ĶMI [Bonello-Palot et al., 2009], CD [Ang et al., 2008, Ferreiro et al., 2010], AKS, arteriāla hipertensija (AH), hiperholesterinēmija, glikozes, kreatinīna līmenis asin̄̄s, trombocītu skaits [Gurbel et al., 2007]. Arī vienlaicīgi lietoto zâlu (piemēram, protonu sūkṇa inhibitori (PSI), statīni) mijiedarbība [Bates et al., 2011, Cuisset et al., 2009] ar klopidogrelu var samazināt antiagreganta izraisīto efektu. Pie šīs grupas pieder arī ar pacientu vistiešāk saistītais koriǵējamais faktors - pacienta līdzestība [Angiolillo et al., 2007].

\section{Zāḷu mijiedarbība}

Tā kā aktīvo metabolītu veido CYP450 izoenzīmi, no kuriem daži ir polimorfiski vai tos inhibē citas zāles, ne visiem pacientiem tiek panākta atbilstoša trombocītu inhibīcija. N̦emot vērā to, ka kopā ar antiagregantu terapiju tiek nozīmētas arī citas zāles, piemēram, holesterīna un glikozes līmeni pazeminošie līdzekḷi, antihipertensīvie līdzekḷi ar mērķi samazināt KV risku, pieaug zāḷu mijiedarbības iespēja. Mijiedarbību var novērot, sākot ar divu vienlaicīgu zāļu lietošanu, kurām raksturīgs metabolisms aknās [Bates et al., 2011].

Klopidogrela aktīvā metabolìta izveidē oksidatīvās biotransformācijas ceḷā, kurš ir CYP atkarīgs, vislielākā loma raksturīga CYP2C19 izoenzīmiem, mazāka ietekme ir arī CYP3A4/5, CYP2B6, CYP1A2, CYP2C9 [Hochholzer et al., 2010, Mega et al., 2009]. 


\section{Protonu sūkṇa inhibitori (PSI)}

PSI tiek rekomendēti kā gastroprotektori pacientiem ar duālu antiagregantu terapiju. CYP2C19, CYP3A4 un CYP2C9 izoenzīmi ir iesaistīti gan PSI, gan klopidogrela metabolismā [Kwok et al., 2012]. Šo izoenzīmu loma PSI grupas zāḷu metabolismā variē starp dažādiem grupas pārstāvjiem (skat.1.4. attēlu). Visbiežāk pētījumos tiek analizēta CYP2C19 izoenzīma ietekme uz klopidogrela metabolismu, kas piedalās omeprazola, lansoprazola un esomeprazola metabolismā [Shi et al., 2008].

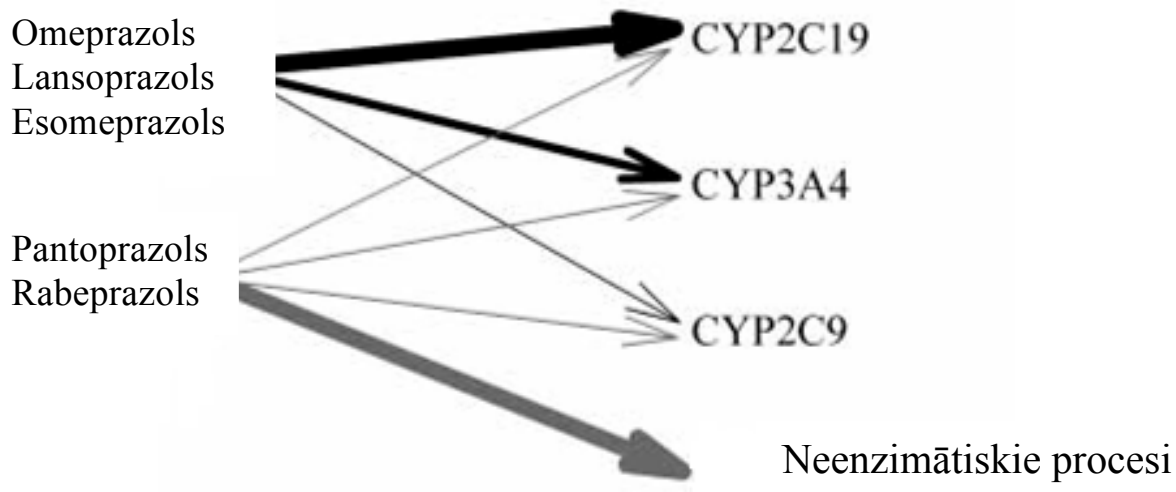

\section{4.att. Protonu sūkṇa inhibitoru aknu metabolisms caur CYP450 enzīmu sistēmu} [Fernando et al., 2011]

Vēl joprojām dati par šo medikamentu mijiedarbību ir pretrunīgi, tomēr pētîjumi biežāk apstiprina omeprazola ietekmi uz klopidogrela efektivitātes samazinājumu [Farid et al., 2010].

Dubultaklā placebo-kontrolētā pētījumā 124 pacientiem pēc PCI ar DAPT (aspirīns $75 \mathrm{mg} /$ dienā un klopidogrels - PD, turpinot UD $75 \mathrm{mg} /$ dienā) tika randomizēti divās grupās - attiecīgi viena grupa saņēma omeprazolu (20 mg / dienā) un otra - placebo. PRI tika noteikts, mērot VASP fosforilāciju pirmajā un septītajā dienā pēc terapijas uzsākšanas. Septîtajā dienā vidējais PRI placebo grupā bija statistiski ticami zemāks - 39,8\% (SD 15,4), salīdzinot ar omeprazola grupu - 51,4\% (SD 16,4) $(p<0,0001)$. Iegūtie rezultāti norāda uz omeprazola spēju statistiski ticami samazināt klopidogrela inhibējošo efektu uz trombocītu $\mathrm{P} 2 \mathrm{Y}_{12}$ receptoriem [Gilard et al., 2008]. 
Šķērsgriezuma pētījumā, kurā tika iekḷauti 1000 pacienti ar klopidogrela terapiju, trombocītu agregācija tika mērīta ar MEA metodi. No iekḷautajiem pacientiem 268 (26,8\%) saṇēm PSI terapiju, attiecīgi pantoprazolu - 162, omeprazolu - 64, esomeprazolu - 42 pacienti. Trombocītu agregācija bija statistiski ticami augstāka omeprazola lietotāju grupā, salīdzinot ar pacientiem, kuri nesaņēma PSI, respektīvi, 295,5 AU*min un 220 AU*min, p=0,001. Starp pārējiem PSI grupas pārstāvjiem šāda veida atšksirība netika novērota [Sibbing et al., 2009].

Neskatoties uz to, ka esomeprazols ir omeprazola strukturālais izomērs, tas lielākā pakāpē tiek metabolizēts caur CYP3A4. Tomēr esomeprazolu lietojot ilgstoši, inhibējošais efekts vairāk būs vērsts uz CYP2C19 izoenzīmu. Lai gan pantoprazols arī tiek metabolizēts caur CYP2C19 un CYP3A4, tomēr tā zemās afinitātes dēl mijiedarbība ir mazāk raksturīga nekā citiem PSI grupas pārstāvjiem [Fernando et al., 2011]. Konkurence par metabolismu caur CYP2C19 izoenzīmu tiek izvirzīta kā mijiedarbības teorētiskais mehānisms, kura rezultātā iespējama klopidogrela kā antiagreganta samazināta efektivitāte vienlaicīgas PSI terapijas laikā, īpaši lietojot omeprazolu, esomeprazolu un lansoprazolu [Blume et al., 2006].

Sastopami ziņojumi arī par samazinātu atbildes reakciju uz klopidogrelu vienlaicīgas lansoprazola terapijas laikā [Small et al., 2008]. Vairāki bioķīmiskie pētījumi liecina par drošāku citu PSI grupas pārstāvju nevis omeprazola izvēli DAPT laikā, lai novērstu farmakokinētiskas un farmakodinamiskas mijiedarbības iespēju [Serebruany et al., 2009].

Ir izvirzịtas teorijas, kā farmakodinamiski varētu mazināt šo mijiedarbības iespēju, un tā rezultātā kā risinājums dažos pêtījumos tika piedāvāts palielināt klopidogrela uzturošo devu (150 mg / dienā) vai ievērot lietošanas režìmu (klopidogrelu un PSI lietot atsevišķi ar 8 līidz 12 stundu intervālu). Prospektīvā, randomizētā pētîjumā, kurā tika iekļauti 20 veseli brīvprātīgie, tika izveidotas divas grupas - viena grupa saṇēma omeprazolu devā 40 mg / dienā vienlaicīgi ar klopidogrelu, otra grupa - zāles lietoja ar 12 stundu intervālu. Mērot VASP fosforilācijas pakāpi pēc vienas nedēlas, nenovēroja PRI statistiski ticamu atšķirīibu starp abām grupām, attiecīgi 56,1\% un $61,6 \%, \mathrm{p}=0,08$ [Ferreiro et al., 2010].

Četros randomizētos, ar placebo kontrolētos pētījumos, kuros piedalījās 282 veseli brīvprātīgie, tika pārbaudīts, vai mijiedarbības iespēja nemazinās, ievērojot šādus zāḷu lietošanas režīmus: pirmā pētījuma dalībnieku grupa saņēma klopidogrelu (300 mg PD, 75 mg UD) un omeprazolu (80 mg / dienā) vienlaicīgi, otra grupa saṇēma šo pašu 
terapiju, bet ar 12 stundu intervālu, trešajai grupai tika nozīmētas palielinātas klopidogrela devas (600 mg PD un 150 mg UD) un ceturtā grupā iekḷautie pētījuma dalībnieki omeprazola vietā saṇēma pantoprazolu $(80 \mathrm{mg} /$ dienā). Mērot trombocītu agregāciju, netika novērotas statistiski ticamas atšķirības starp pirmajām trīs grupām, kas līdz ar to nepierāda laika intervālu lietderību vienlaicīgas terapijas laikā. Tika secināts, ka mijiedarbība pastāv starp klopidogrelu un omeprazolu, bet nevis starp klopidogrelu un pantoprazolu [Angiolillo et al., 2011].

Tiek ziņots arī par PSI devas ietekmi uz iespējamo mijiedarbību ar klopidogrelu. Gilard et al. pētījumā iegūtie dati liecina, ka PSI devā $80 \mathrm{mg} /$ dienā izraisa augstāku trombocītu reaktivitāti klopidogrela lietošanas laikā nekā mazākas devas (40 mg / dienā vai $20 \mathrm{mg} /$ dienā) [Gilard et al., 2008]. Citā pētījumā, salīdzinot divu PSI (omeprazola un pantoprazola) ietekmi uz klopidogrela terapiju, tika iekļauti 104 pacienti pēc PCI. Randomizācija divās grupās tika veikta, balstoties uz PSI, respektīvi, viena grupa saņēma omeprazolu, otra grupa - pantoprazolu devā $20 \mathrm{mg} /$ dienā, abas grupas saṇēma DAPT - klopidogrels 150 mg / dienā un aspirīns 75 mg / dienā. Nosakot PRI ar VASP fosforilācijas metodi pacientiem pēc viena mēneša, pantoprazola lietotāju grupā konstatēja labāku atbildes reakciju uz klopidogrela terapiju nekā omeprazola grupā $(36 \pm 20 \%$ pret $48 \pm 17 \%, p=0,007)$. Omeprazola lietotāju grupā bija vairāk pacientu ar novērotu klopidogrela samazinātu efektivitāti, salīdzinot ar pantoprazola grupu (44\% pret 23\%, p=0,04) [Cuisset et al., 2009]. Līdzīgi rezultāti novēroti arī citos pētījumos, iesakot labāk izvēlēties pantoprazola terapiju vai esmopeprazola vietā lietot ranitidīnu, lai izvairītos no samazinātas klopidogrela efektivitātes [Angiolillo et al., 2011].

Zinātniskā literatūrā sastopams viedoklis ar̄̄ par citu iespēju mijiedarbības mazināšanai, attiecīgi palielinot klopidogrela UD pacientiem, kuri vienlaicīgi saṇem PSI terapiju. Moceri et al. pētījuma rezultāti apliecina pārliecinošu palielinātas klopidogrela UD efektivitāti esomeprazola terapijas laikā, samazinot pacientu skaitu ar novērotu hiporesponsivitāti [Moceri et al., 2011].

Debates par PSI iespējamo negatīvo ietekmi uz klopidogrela terapijas efektivitāti vēl joprojām turpinās [Cialdella et al., 2013]. Pagājušā gadā publicētais zinātniskais pārskats, iekḷaujot 4693 pacientus no 19 pētījumiem, apstiprina datus par biežāk sastopamu omeprazola mijiedarbību ar klopidogrelu. Tā kā zinātniskie pētìjumi par šīs mijiedarbības patieso ietekmi un nozīmību vēl turpinās, tad šobrīd izvēle tiek atstāta ārsta ziņā, lai izvērtētu gastrointestinālo risku kungǵa čūlas un gastrointestinālas asiņošanas attīstībai antiagregantu terapijas laikā [Kwok et al., 2012]. Pastāv arī 
viedoklis, ka PSI (īpaši omeprazola un esomeprazola) terapija varētu būt kā marķieris, bet ne kā cēlonis KV notikumu attīstībai [Goodman et al., 2012]. Pastāvot norādēm uz atsevišksu PSI, piemēram, omeprazola un esomeprazola, nelabvēlīgu ietekmi uz klopidogrela efektivitāti CYP2C19 inhibīcijas dēḷ, vēlams ievērot piesardzību, izvēloties PSI pacientam, kurš saņem klopidogrelu. Zinātniskie pierādījumi par ietekmi uz klīnisko iznākumu ir pretrunīgi.

\section{Statīni}

Statīnu darbības mehānisms saistās ar 3-hidroksi-3-metilglutarilkoenzīma A (HMG-CoA) reduktāzes inhibīciju, veicinot samazinātu holesterīna sintēzi aknās. CYP3A4 piedalās lipofīlo statīnu (lovastatīns, simvastatīns un atorvastatīns) eliminācijā, savukārt hidrofîlo statīnu (fluvastatīns, pravastatīns un rosuvastatīns) metabolismā tam nav tik svarīga loma [Zahno et al., 2010]. Atorvastatīns ir visbiežāk lietotais statīns holesterīna līmeņa redukcijai pacientiem ar KSS, un tā aknu metabolisms var palielināt mijiedarbības iespēju vienlaicīgi lietoto zāḷu gadījumā. Atorvastatīna kalcija sāls organismā tiek pārvērsta par skābes un laktona metabolītiem. Lai gan tieši skābes forma inhibē HMG-CoA reduktāzi, vissvarīgākais eliminācijas process rakturīgs laktona formai, kas l̦oti cieši piesaistās pie CYP3A4 izoenzīma, salīdzinot ar citām konkurējošām zālēm, piemēram, ciklosporīnu, eritromicīnu, amiodaronu, verapamilu, fluoksetīnu, kā arī ar greifrūtu sulu [Lewis, 2010]. Atorvastatīnam kā CYP3A4 inhibitoram ex vivo ir novērota devas atkarīga ietekme uz klopidogrela metabolismu [Bates et al., 2011, Lau et al., 2003], bet debates par šīs mijiedarbības efektu in vivo joprojām turpinās [Suh et al., 2013]. Lai gan rosuvastatīna metabolismā iesaistîts cits izoenzīms - CYP2C9 [White, 2002], kura dēl sagaidāma mazāka ietekme uz klopidogrela efektivitāti, tomēr jaunākie pētîjumi aktualizē arī šo mijiedarbības iespēju [Poyet et al., 2010, Malmstrom et al., 2009].

SPICE (Evaluation of the Influence of Statins and Proton Pump Inhibitors on Clopidogrel Antiplatelet Effects) pētījumā neatrada atšksirību starp atorvastatīna un rosuvastatīna ietekmi uz klopidogrela antiagregatīvo efektu. Šajā pētījumā tika iekḷauti 350 pacienti pēc PCI ar klopidogrela terapiju un pirmo mēnesi viena grupa saṇēma rosuvastatīnu $(20 \mathrm{mg} /$ dienā) un otra grupa - atorvastatīnu $(80 \mathrm{mg} /$ dienā). Pēc 30 dienām veica trombocītu reaktivitātes pārbaudi ar LTA, nosakot maksimālo trombocītu agregāciju, un VASP analīzi, lai noteiktu PRI. Pēc 30 dienām šie pacienti tika 
randomizēti četrās grupās gastroprotektīvo līzekḷu saņemšanai: esomeprazols, pantoprazols, omeprazols vai ranitidīns. Pēc 60 dienām pacientiem veica atkārtotu trombocītu funkciju analīzi un konstatēja PRI kāpumu pacientiem ar esomeprazola un omeprazola terapiju.

Savukārt citā pētījumā, kur tika pārbaudīta atorvastatīna un rosuvastatīna ietekme uz trombocītu reaktivitāti, pēc tūlītējas terapijas uzsākšanas netika novērotas atšķirības starp abām pacientu grupām, savukārt apsekošanas vizītes laikā pēc 6 mēnešiem rosuvastatīna grupā trombocītu reaktivitāte bija statistiski ticami augstāka nekā atorvastatīna grupā $(241,5 \pm 88,2$ vs $226,4 \pm 79,3 ; p=0,033)$ [Suh et al., 2013]. Novērotās trombocītu reaktivitātes atšķirības statīnu ilgstošas terapijas rezultātā mudina veikt papildu pētījumus, lai izskaidrotu ilgstošas statīnu terapijas ietekmi uz klopidogrela metabolismu.

TRITON-TIMI 38 (Trial to Assess Improvement in Therapeutic Outcomes by Optimizing Platelet Inhibition With Prasugrel - Thrombolysis in Myocardial Infarction 38) pētījumā ( $\mathrm{n}=13$ 608; pacienti ar AKS un plāna PCI), kur analizēja statīnu ietekmi uz klīnisko iznākumu biežumu, nelabvēlīgu KV notikumu (KV nāve, MI, CI) pieaugums iespējamas klopidogrela hiporesponsivitātes dēl zālu mijiedarbības rezultātā netika novērots ne pacientiem ar statīnu monoterapiju, ne arī kombinētās terapijas laikā ar KKB un / vai PSI [Ojeifo et al., 2013].

Atorvastatīnam raksturīga spēja inhibēt ADF, tādējādi kavējot trombīna aktivētu trombocītu agregāciju. Šīs īpašības dēl pētîjumos ziṇots arī par sinerǵisku devas atkarīgu mijiedarbību starp atorvastatīnu un klopidogrelu, kā rezultātā antiagreganta efektivitāte palielinās [Leoncini et al., 2013]. Līdz ar to jaunākajā zinātniskajā literatūrā paaugstinātas trombocītu reaktivitātes gadījumā pacientiem ar standarta klopidogrela UD (75 mg / dienā) un atorvastatīnu mazā devā (10 mg / dienā) kā alternatīva tiek piedāvāta atorvastatīna nomaiņa uz citu statīnu grupas zāḷu līdzekli, kuram nav raksturīgs CYP3A4 metabolisms [Park et al., 2012], vai arī atorvastatīna devas palielināšana (80 mg / dienā), tādā veidā uzlabojot pacienta individuālo atbildes reakciju uz klopidogrela terapiju [Leoncini et al., 2013, Schmidt et al., 2012].

\section{Kalcija kanālu blokatori (KKB)}

Dihidropiridīna grupas KKB ir CYP4503A4 izoenzīma, kas piedalās klopidogrela aktivācijas procesā, inhibitori. Līdz ar to vienlaicīga KKB lietošana tiek 
saistīta ar samazinātu trombocītu inhibīciju klopidogrela lietošanas laikā [Siller-Matula et al., 2008]. Pētījumā, kurā tika pārbaudīta ADF izraisīta trombocītu reaktivitāte ar divām metodēm (LTA un VerifyNow analīze), 162 pacientiem pēc PCI ar stenta implantāciju, KKB vienlaicīga lietošana tika izvirzīta $k \bar{a}$ iespējamais cēlonis samazinātai klopidogrela efektivitātei. Pacientiem ar KKB terapiju tika konstatēta statistiski ticami augstāka trombocītu reaktivitāte, salīdzinot ar pacientu grupu bez KKB ( $p=0,001$, neatkarīgi no izmantotās metodes). Daudzfaktoru regresijas analīzē KKB terapija tika apstiprināta kā neatkarīgs faktors klopidogrela izraisītas trombocītu inhibīcijas samazinājumam ( $\mathrm{p}=0,006$ ar LTA un $\mathrm{p}=0,004$ ar VerifyNow metodi) [Gremmel et al., 2010].

Citā pētījumā atbildes reakcija uz klopidogrela terapiju tika noteikta, mērot VASP fosforilācijas pakāpi un izmantojot agregometrijas metodi. Pētījumā tika iekļauti 200 pacienti ar KSS pēc PCI. PRI ar VASP fosforilācijas metodi bija augstāks pacientiem, kas saṇēma klopidogrelu kopā ar KKB (61\%), salīdzinot ar pacientiem bez KKB (48\%). Absolūtā PRI atšķirīiba starp šīm divām grupām bija 13\% (95\% CI: 620\%; p=0,001), savukārt relatīvā atšksirība sasniedza 21\%. Samazināta trombocītu inhibīcija (definēta kā PRI >69\%) tika novērota kopumā 40\% pacientu, kas saṇēma KKB terapiju un $20 \%$ pacientu bez KKB (Hī - kvadrāta tests, $\mathrm{p}=0,008)$. ADF izraisīta trombocītu agregācija bija par 30\% augstāka pacientiem ar KKB, salīdzinot ar otru grupu ( $\mathrm{p}=0,046)$ [Siller-Matula et al., 2008].

Dažiem no KKB piemīt spēja inhibēt zāḷu transportieri P-gp, kas nodrošina arī klopidogrela absorbciju tievajās zarnās. Šo KKB grupas pārstāvju atšķirīgo ietekmi uz P-gp pārbaudīja citā pētîjumā, kur mērīja trombocītu reaktivitāti 623 pacientiem pēc PCI ar duālu antiagregantu terapiju, izmantojot LTA metodi. 222 (35,6\%) pacienti saņēma KKB terapiju, no kuriem 98 pacienti lietoja KKB ar P-gp inhibējošām īpašībām (verapamils, nifedipīns, diltiazems) un 124 pacienti saņēma amlodipīnu - KKB bez Pgp inhibitora īpašībām. Vidējā ADF izraisīta trombocītu reaktivitāte bija statistiski ticami augstāka abās KKB lietotāju grupās, salīdzinot ar pacientiem bez KKB $(p<0,05)$. Jāatzīmēe, ka tikai amlodipīna terapijas laikā ieguva 2,3 reizes lielāku risku klopidogrela samazinātai efektivitātei [Harmsze et al., 2010].

Kopumā sastopama pretrun̄̄ga informācija par klopidogrela un KKB mijiedarbību. Dažos pētījumos iegūtie rezultāti noliedz KKB ietekmi uz antiagreganta terapiju [Schmidt et al., 2012, Olesen et al., 2011]. CREDO (Clopidogrel for the Reduction of Events During Observation) pētījuma laikā, izvērtējot ilgtermin̄ā 
iespējamo KKB un klopidogrela mijiedarbību, netika novērota klīniski nozīmīga KKB ietekme uz klopidogrela efektivitāti [Good et al., 2012]. Savukārt citā pētījumā, kurā tika novērota vairāku vienlaicīgi pastāvošu riska faktoru $\left(C Y P 2 C 19^{*} 2, \mathrm{KKB}, \mathrm{PSI}\right)$ ietekme, klopidogrela efektivitātes samazinājums bija gan pacientiem ar vienlaicīgu $\mathrm{KKB}$ un PSI terapiju, gan arī KKB lietotājiem ar $C Y P 2 C 19^{*} 2$ samazinātas funkcijas alēli [Harmsze et al., 2011].

\section{Palielināts ķermen̦a masas indekss (ĶMI)}

Kā viens no iespējamiem klopidogrela hiporesponsivitāti veicinošiem mehānismiem pētījumos minēts arī palielināts ĶMI [Celik et al., 2009, Feher et al., 2007]. Feher et al. pētījumā, kur tika analizēta vairāku faktoru loma klopidogrela rezistences attīstībā, ĶMI pacientu grupās atšķīrās statistiski ticami, respektīvi, pacientu grupā ar normālu klopidogrela darbību ĶMI bija zemāks, salīdzinot ar rezistento pacientu grupu (attiecīgi 26,1 vs $28,8 \mathrm{~kg} / \mathrm{m}^{2}, \mathrm{p}<0,05$ ) [Feher et al., 2007].

Prospektīvā multicentru pētījumā, kurā tika ieklauti 73 pacienti pēc PCI, tika pētīta klīnisko faktoru ietekme uz palielinātu trombocītu reativitāti (definēta kā VASP PRI $\geq 50 \%$ pēc klopidogrela PD 600mg saņemšanas). Palielināts ĶMI bija viens no faktoriem, kuram tika novērota asociācija ar paaugstinātu trombocītu reaktivitāti $(\mathrm{p}=0,01)$ [Bonello-Palot et al., 2009].

Pankert et al. veiktajā pētījumā, kurā analizēja ĶMI ietekmi uz klopidogrela efektivitāti, lietojot standarta UD (75 mg /dienā) un palielinātu klopidogrela UD (150 mg /dienā), adipozitāte (ĶMI $\left.>30 \mathrm{~kg} / \mathrm{m}^{2}\right)$ biežāk bija raksturīga pacientu grupā ar klopidogrela hiporesponsivitāti (VASP PRI $\geq 50 \%$ ) netakarīgi no UD režīma [Pankert et al., 2013]. Citā pêtījumā, neskatoties uz adipozitātes izplatî̉bu pētījuma pacientu vidū (44\%), tomēr asociācija starp ĶMI un klopidogrela hiporesponsivitāti netika novērota [Gaglia et al., 2011].

\section{Smēḳēšana}

N̦emot vērā klopidogrela nepieciešamo aktivāciju ar daudziem aknu CYP450 izoenzīmiem, tajā skaitā arī ar CYP1A2, literatūrā ziņots par smēķēšanas kā šī izoenzīma induktora spēju veicināt klopidogrela aktīvā metabolīta izveidi. Bliden et al. pētījumā, analizējot smēķēšanas ietekmi uz trombocītu agregāciju, tika iekḷauti 259 
pacienti, kuri tika stacionēti plāna PCI veikšanai. 120 pacienti jau iepriekš bija lietojuši klopidogrelu un nesaņēma PD, savukārt 139 pacienti pirms procedūras veikšanas saņēma klopidogrela 600 mg PD. No visiem pētījumā iekļautajiem pacientiem 104 bija smēķētāji un 155 - nesmēķēetāji. Smēķētāju grupā, kas jau iepriekš bija saņēmuši klopidogrela terapiju, konstatēja zemāku trombocītu agregāciju, salīdzinot ar nesmēķēetājiem $(p<0,0008)$. Šì sakarība starp grupām atšķirībā no smēķěšanas statusa statistiski ticami saglabājās arī pacientiem, kuri pirms procedūras saṇēma klopidogrelu ( $\mathrm{p}<0,05)$. Pētījums pierādīja, ka klopidogrela terapija smēķētājiem saistās ar lielāku trombocītu inhibīciju un zemāku agregāciju, salīdzinot ar nesmēķētājiem [Bliden et al., 2008].

Gremmel et al. pētījumā, kurā tika iekḷauti 102 pacienti (40 aktīvi smēķētāji, 23 pacienti, kas iepriekš smēķējuši un 33 nesmēķētāji), mērot trombocītu agregāciju 24 stundas pēc PCI, lielāku ADF izraisītu trombocītu agregāciju konstatēja nesmēķētājiem, salīdzinot ar aktīvo smēķētāju grupu (14 pret 5; p=0,004) [Gremmel et al., 2009].

Citā pētījumā tika iekl̦auti 134 otrā tipa CD pacienti ar DAPT, kuri tika sadalīti atkarībā no seruma kotinīna līmeņa trīs sekojošās grupās: <3ng/ml (nesmēḳētāji), 3-199ng/ml (neregulārie smēķētāji) un Z200ng/ml (aktīvie smēķētāji). Pārbaudot trombocītu funkcijas analīzi ar trīs dažādām metodēm (LTA, VerifyNow P2Y 12 un VASP fosforilācijas metode), novēroja, ka seruma kotinīna līmenis ir pretēji proporcionāls trombocītu reaktivitātei, mērot ar visām metodēm, respektīvi, pieaugot kotinīna līmenim, samazinās trombocītu agregācija $(\mathrm{p}<0,0001)$. Līdz ar to tika secināts, ka smēķēšana CD pacientiem samazina trombocītu reaktivitāti klopidogrela terapijas laikā [Ueno et al., 2012]. Tomēr nepieciešams veikt lielus prospektīvus pētījumus, kas apstiprinātu smēķēšanu kā cēloni klopidogrela aktīvā metabolīta pastiprinātai produkcijai.

\section{Cukura diabēts (CD)}

N̦emot vērā pieaugošo CD prevalenci visā pasaulē, pieaug arī ar CD saistītās komplikācijas, kas bieži vien izpaužas kā KSS. Trombocītu disfunkcija tiek asociēta kā pieaugošo koronāro artēriju slimības riska centrālais veicinātājs. Līdz ar to klopidogrels ir īpaši nozīmīgs nelabvēlīgo klīnisko iznākumu samazinātājs pacientiem ar AKS un pēc PCI [Hall et al., 2011]. 
Pētījumos, kuros tiek analizēta klīnisko faktoru asociācija ar paaugstinātu trombocītu reaktivitāti, bieži vien kā viens no ietekmējošiem faktoriem tiek minēts arī CD [Bonello-Palot et al., 2009]. Farmakodinamiskie pētījumi pierāda pastāvošu augstu trombocītu reaktivitāti pacientiem ar CD, neskatoties uz klopidogrela terapiju. Pētîjuma, kurā apkopoja dāņu reǵistra datus laika posmā no 2002. līdz 2009. gadam, tika iekḷauti 58851 pacienti pēc hospitalizācijas MI dēḷ, kas tika novēroti turpmāko vienu gadu. Kā nelabvēlīgi klīniski iznākumi tika vērtēta nāve (KV vai cits cēlonis) un atkārtots MI. Pacientiem ar CD klopidogrela terapijai pēc MI tika konstatēta zemāka riska redukcija nāvei jebkura iemesla dēḷ un nāvei KV cēloṇa dēḷ, salīdzinot ar pacientiem bez CD [Andersson et al., 2012].

Citā pētījumā, kura mērķis bija identificēt riska faktorus samazinātai trombocītu rekativitātei, tika iekļauti 157 pacienti ar KV slimību, kuri saņēma klopidogrela terapiju ( $75 \mathrm{mg} /$ dienā $>$ vai $=7$ dienas vai $600 \mathrm{mg}$ PD $>$ vai $=24$ stundas pirms iekḷuš̌anas). Nosakot trombocītu reaktivitāti ar VerifyNow metodi, zemāks trombocītu inhibīcijas līmenis bija pacientiem ar paaugstinātu plazmas fibrinogēna līmeni ( $\geq 375 \mathrm{mg} / \mathrm{dl}), \mathrm{CD}$ pacientiem un pacientiem ar palielinātu ĶMI $\left(\geq 25 \mathrm{~kg} / \mathrm{m}^{2}\right)$. Tā kā paaugstināts plazmas fibrinogēna līmenis bija saistīts ar CD, līdz ar to trombocītu inhibīcija CD pacientiem bija zemāka, salīdzinot ar pacientiem bez CD $(23,9 \pm 3,9 \%$ pret $45,1 \pm 4,5 \%, \mathrm{p}<0,001)$ [Ang et al., 2008].

Singla et al. pētījumā, kurā tika meklēta saistība starp trombocītu reaktivitāti un glikēmijas kontroli DAPT laikā pēc PCI, tika mērīta trombocītu agregācija pacientiem ar $\operatorname{CD}(n=36)$ un pacientiem bez $\operatorname{CD}(n=35)$. Glikētā hemoglobīna $\left(\mathrm{Hb}_{\mathrm{A} 1 \mathrm{C}}\right)$ mērījumi tika sagrupēti divās grupās: $\mathrm{Hb}_{\mathrm{A} 1 \mathrm{C}}<7 \mathrm{~g} / \mathrm{dL}(\mathrm{n}=16)$ un $\mathrm{Hb}_{\mathrm{A} 1 \mathrm{C}} \geq$ 7g/dL (n=20). CD pa-cientiem ar $\mathrm{Hb}_{\mathrm{AlC}} \geq 7 \mathrm{~g} / \mathrm{dL}$ bija vērojama augstāka ADF izraisīta trombocītu agre-gācija, salīdzinot ar $\mathrm{CD}$ pacientiem, kuriem $\mathrm{Hb}_{\mathrm{AlC}}<7 \mathrm{~g} / \mathrm{dL}$ $(54 \pm 15$ pret $34 \pm 14, \mathrm{p}<0,001)$. CD pacientiem ar $\mathrm{Hb}_{\mathrm{A} 1 \mathrm{C}} \geq 7 \mathrm{~g} / \mathrm{dL}$ paaugstinātas trombocītu reaktivitātes prevalence bija $65 \%$, bet $\mathrm{CD}$ pacientiem ar $\mathrm{Hb}_{\mathrm{A} 1 \mathrm{C}}<7 \mathrm{~g} / \mathrm{dL}-$ 19\%. Pētījumā secināja, ka pastāv sakarība starp glikēmisko kontroli un trombocītu reaktivitāti otrā tipa $\mathrm{CD}$ pacientiem ar klopidogrela terapiju, jo slikti kontrolēts $\mathrm{CD}$ izraisa palielinātu trombocītu reaktivitāti [Singla et al., 2009].

Optimizējot antiagregantu terapiju CD pacientiem (OPTIMUS - Optimizing anti-Platelet Therapy In diabetes MellitUS), tika pierādīts, ka palielināta klopidogrela UD (150 mg / dienā) CD pacientiem ir efektīvāka, salīdzinot ar standarta 
UD (75 mg / dienā), tomēr vēl joprojām saglabājās augsta trombocītu agregācija [Angiolillo et al., 2007].

CD pacientiem ir raksturīga pastiprināta aktivācijas marķieru un trombocītu visrmas receptoru - purīnerǵisko receptoru P2Y, G-proteīna, P2 Y 12, GP Ib, GP IIb/IIIa, P-selektīna ekspresija. Palielinās arī trombocītu intracelulārā kalcija koncentrācija, kas izraisa pastiprinātu trombocītu degranulāciju un agregāciju. CD pacientiem trombocīti parasti ir arī ar lielāku virsmu, izmēru un tilpumu, tādējādi veicinot papildu agregāciju un aktivāciju [Galla et al., 2009, Yilmaz et al., 2008]. Šiem pacientiem raksturīga arī reaktīvā skābekḷa un slāpekḷa produkcija, samazināta trombocītu antioksidantu veidošanās, veicinot pastiprinātu trombocītu aktivāciju un samazinot endoteliālo šūnu slāpekḷa oksīda un prostaciklīna sintēzi. Līdz ar to, pastāvot insulīna rezistencei, novēro saistību starp CD un pieaugošo KSS risku gan akūtām koronārām komplikācijām, gan ST pēc PCI [Ferreiro et al., 2010].

Ghannudi et al. pētîjumā tika analizēta zemas trombocītu atbildes reakcijas uz $\mathrm{P}^{2} \mathrm{Y}_{12}$ receptoru antagonistu terapiju, mērot VASP fosforilācijas līmeni ar plūsmas citometru, saistība ar nelabvēlīgu klīnisko iznākumu biežumu pacientiem ar vai bez CD pēc PCI. 436 pacienti tika iedalīti četrās grupās, balstoties uz CD esamību un trombocītu reaktivitāti (pazemināta, ja PRI >61\%). Pēc $9 \pm 2$ mēnešu FUP kopējās un kardiālās mirstības un ST biežums bija augstāks CD pacientiem ar samazinātu trombocìtu atbildes reakciju [El Ghannudi et al., 2011].

Pasaulē starp pieaugušiem (20-79 gadi) CD prevalence 2010. gadā bija apmēram 6,4\%, skarot aptuveni 285 miljonus pieaugušo, bet, pastāvot pieaugošai šīs slimības izplatībai, 2030. gadā jau tiek prognozēts lielāks CD pacientu skaits $-7,7 \%$ (439 miljoni) [Balasubramaniam et al., 2012]. Šī tendence aktualizē antiagregantu terapijas kontroli CD pacientiem, balstoties uz iepriekš minēto pētījumu rezultātiem.

\section{Pacientu līdzestība}

Pacienta līdzestības trūkums vai neadekvāta devas izvēle ir biežākie cēloṇi klopidogrela samazinātas efektivitātes attīstībai. Klopidogrela rezistence bieži vien saistās arī ar aspirīna rezistenci. Pētījumā konstatēts, ka apmēram 50\% no pacientiem ar aspirīna rezistenci novēro arī klopidogrela rezistenci (tā var arī būt neatkarīgi). Šādai duālas antiagregantu rezistences grupai pacientu līdzestības trūkuma apstākḷlos ir īpaši paaugstināts risks trombotisko komplikāciju attīstībai pēc PCI [Lev et al., 2006]. 


\subsection{Pacientu uzraudzība ar samazinātu klopidogrela atbildes reakciju}

Iepriekš veiktajos pētījumos pacientiem pēc PCI lielāka klopidogrela PD (600 mg) asociējās ar lielāku trombocītu inhibīcijas pakāpi, zemāku vidējo reaktivitāti uz ADF terapijas laikā, mazāku nepietiekamas efektivitātes gadījumu skaitu, salīdzinot ar 300 mg PD [Gurbel et al., 2005, Gurbel et al., 2005]. ISAR-CHOICE (Intracoronary Stenting and Antithrombotic Regimen: Choose Between 3 High Oral Doses for Immediate Clopidogrel Effect) pētījumā netika novērots lielāks klopidogrela aktīvā metabolīta līmenis pie dažādām PD, attiecīgi 600 mg un 900 mg [von Beckerath et al., 2005]. Pêtījuma rezultāti liecina, ka klopidogrela PD $>600$ mg laikā nenovēro papildu trombocītu finkcijas nomākumu, ko iespējams izskaidrot ar ierobežoto klopidogrela absorbciju. Tomēr 600 mg PD raksturojas ar ātrāku trombocītu inhibīciju nekā 300 mg [Gurbel et al., 2005]

OASIS-7 (Optimal Antiplatelet Strategy for Interventions 7) pētījumā tika iekļauti 25087 pacienti ar nestabilu stenokardiju vai akūtu MI, izmantojot divus atšķirīgus klopidogrela devu režīmus. Viena grupa saņēma klopidogrela terapijas standarta devas - $300 \mathrm{mg}$ PD, $75 \mathrm{mg} /$ dienā UD, bet otrai grupai tika nozīmētas paaugstinātas klopidogrela devas - $600 \mathrm{mg}$ PD, $150 \mathrm{mg}$ / dienā UD vienu nedēḷu. Pēc 30 dienām tika apsekots nelabvēlīgo iznākumu (KV nāve, MI, CI) biežums abās terapijas grupās. Netika novērotas iepriekš minēto notikumu atšķkirības, attiecīgi 4,4\% standarta terapijas grupā un 4,2\% - paaugstinātu devu grupā. Apmēram divām trešdaḷām pacientu, kuriem tika veikta PCI, tika novērots samazināts risks ST, par 30\% un par $22 \%$ samazinājās MI risks pacientu grupā, kas saņēma augstākas klopidogrela devas, salīdzinot ar standarta terapiju. Palielināto devu grupā biežāk novēroja asiņošanu, lai gan intrakraniālas vai fatālas asiņošanas risks šajā grupā nebija pieaudzis [Mehta et al., 2010].

Lai gan paaugstinātas klopidogrela PD un UD var uzlabot terapijas efektivitāti [Gladding et al., 2008], tomēr vēl joprojām pacientu vidū pastāv atšķirības starp indivīdiem. Bonello et al. pētījumā, kurā nelielam pacientu skaitam, kam plānots veikt PCI, tika nozīmētas papildu PD līdz optimāla antiagregatīvā efekta sasniegšanai, veicot trombocītu funkciju monitorēšana ar VASP metodi [Bonello et al., 2008], pielietotā modificēto devu stratēgija tika atzīta par diezgan drošu metodi ar iespēju uzlabot klīnisko iznākumu pacientiem ar klopidogrela rezistenci, neskatoties uz 600 mg PD saņemšanu pirms PCI. Devu pielāgošana, balstoties uz trombocītu funkciju 
mērījumiem, izskatās daudzsološa pieeja optimālas pacientu aprūpes nodrošināšanai. Pretrun̄̄gi rezultāti iegūti GRAVITAS (The Gauging Responsiveness With a VerifyNow P2Y12 Assay: Impact on Thrombosis and Safety) pētījumā, kas liecina, ka klopidogrela terapijas korekcija, izvēloties paaugstinātas UD (150 mg / dienā) režīmu pacientiem pēc PCI ar klopidogrela rezistenci, neuzrāda lielāku efektivitāti, salīdzinot ar standarta uzturošo devu (75 mg / dienā) [Wiviott et al., 2007].

\subsection{Jaunākie antiagreganti, to priekšrocības un trūkumi}

Antiagregantu hiporesponsivitātes un rezistences jautājums aktualizējis jaunu š̄s grupas zāḷu attīstību ar zināmām priekšrocībām attiecībā pret citiem pārstāvjiem: samazināta ǵenētisko polimorfísmu spēja izmainīt šo zāļu darbību organismā un retāk novērotas zāḷu mijiedarbības reakcijas [Hochtl et al., 2012]. Antiagregantu farmakokinētisko un farmakodinamisko īpašību salīdzinājums atspoguḷots 1.4. tabulā.

\section{Jaunāko antiagregantu salīdzinājums ar klopidogrelu}

[Siller-Matula et al., 2009, Damman et al., 2012, Toma, 2010, Kalyanasundaram et al., 2011]

\begin{tabular}{|c|c|c|c|}
\hline Parametri & Klopidogrels & Prasugrels & Tikagrelors \\
\hline $\begin{array}{l}\text { Kūmiskāā } \\
\text { struktūrformula }\end{array}$ & & & \\
\hline Zāḷu grupa & Tienopiridīni & Tienopiridīni & $\begin{array}{l}\text { Ciklopentiltriazolpirimi- } \\
\text { dīni (CPTP) }\end{array}$ \\
\hline $\begin{array}{l}\text { Darbības } \\
\text { mehānisms }\end{array}$ & $\begin{array}{l}\text { neatgriezeniski } \\
\text { saistās ar P2Y } Y_{12} \\
\text { receptoriem }\end{array}$ & $\begin{array}{l}\text { neatgriezeniski } \\
\text { saistās ar } \mathrm{P} 2 \mathrm{Y}_{12} \\
\text { receptoriem }\end{array}$ & $\begin{array}{l}\text { atgriezeniski saistās ar } \\
\mathrm{P}^{2} \mathrm{Y}_{12} \text { receptoriem }\end{array}$ \\
\hline Devas & $\begin{array}{l}\text { PD: } 300-600 \mathrm{mg} \\
\text { UD: } 75 \mathrm{mg} 1 \mathrm{x} \\
\text { dienā }\end{array}$ & $\begin{array}{l}\text { PD: } 60 \mathrm{mg} \\
\text { UD: } 10 \mathrm{mg} 1 \mathrm{x} \\
\text { dienā }\end{array}$ & $\begin{array}{l}\text { PD: } 180 \mathrm{mg} \\
\text { UD: } 90 \mathrm{mg} \\
\text { 2x dienā }\end{array}$ \\
\hline Lietošanas veids & perorāli & Perorāli & perorāli \\
\hline \multicolumn{4}{|l|}{$\begin{array}{l}\text { Farmakokinētiskās } \\
\text { ipašības: }\end{array}$} \\
\hline Iedarbības sākums & $2-4 \mathrm{~h}(300 \mathrm{mg})$ & $0,5-1,5 \mathrm{~h}(60 \mathrm{mg})$ & $1-3 \mathrm{~h}$ \\
\hline
\end{tabular}




\begin{tabular}{|c|c|c|c|}
\hline Biopieejamība & $>50 \%$ & $\geq 79 \%$ & $\sim 36 \%$ \\
\hline $\begin{array}{l}\text { Eliminācijas } \\
\text { puseriods }(t \text { 1/2) }\end{array}$ & $\sim 6-8 \mathrm{~h}$ & $\begin{array}{l}\sim 7 \mathrm{~h}(2-15 \mathrm{~h}- \\
\text { aktīvs metabolīts })\end{array}$ & $\sim 7-8,5 \mathrm{~h}(6-13 \mathrm{~h})$ \\
\hline 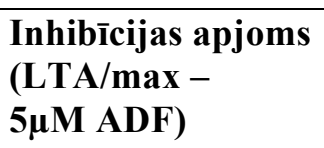 & $\sim 40 \%$ & $\sim 60-80 \%$ & $\sim 75-90 \%$ \\
\hline Parametri & Klopidogrels & Prasugrels & Tikagrelors \\
\hline Metabolisms & $\begin{array}{l}\text { CYP2C19 un } \\
\text { CYP } 3 A 4\end{array}$ & $\begin{array}{l}\text { CYP } 3 A 4 \text { un } \\
C Y P 2 B 6\end{array}$ & CYP3A4 un $C Y P 3 A 5$ \\
\hline Eliminācija & $\begin{array}{l}40 \% \text { ar urīnu, } 35- \\
60 \% \text { izkārnījumos }\end{array}$ & $\begin{array}{l}\text { 68\% urīnā, } 27 \% \\
\text { izkārnījumos }\end{array}$ & $\begin{array}{l}\text { 57\% izkārnījumos, } 26 \% \\
\text { urīnā }\end{array}$ \\
\hline $\begin{array}{l}\text { Mijedarbība ar } \\
\text { citiem } \\
\text { medikamentiem }\end{array}$ & $\begin{array}{l}\text { CYP3A4: Kalcija } \\
\text { antagonisti } \\
\text { (verapamils, } \\
\text { diltiazems, mazākā } \\
\text { mērā felodipīns, } \\
\text { nifedipīns, } \\
\text { amlodipīns); } \\
\text { Statīni } \\
\text { (atorvastatīns, } \\
\text { simvastatīns); } \\
\text { CYP2C19 inhibitori: } \\
\text { PSI (omeprazols, } \\
\text { esomeprazols), } \\
\text { pretepilepsijas } \\
\text { līdzekḷi } \\
\text { (karbamazepinns, } \\
\text { okskarbamazepinns); } \\
\text { CYP2C9: NPL } \\
\text { (naproksēns) }\end{array}$ & $\begin{array}{l}\text { Zema mijiedarbības } \\
\text { varbūtība: } \\
\text { NPL } \\
\text { Varfarīns }\end{array}$ & $\begin{array}{l}\text { CYP3A4 inhibitori: } \\
\text { a) spēcīgi inhibitori - } \\
\text { ketokonazols, } \\
\text { klaritromicīns, ritonavirs, } \\
\text { atazanavirs; } \\
\text { b)mēreni inhibitori: } \\
\text { diltiazems, eritromicīns, } \\
\text { flukonazols; } \\
\text { CYP3A4 induktori: } \\
\text { rifampicīns, } \\
\text { deksametazons, fenitoīns, } \\
\text { karbamazepīns, } \\
\text { fenobarbitāls. } \\
\text { Medikamenti, kas } \\
\text { paaugstina asiñošanas } \\
\text { risku: aspirīns, NPL; } \\
\text { Citi } C Y P 3 A 4 \text { substrāti: } \\
\text { statīni (lovastatīns, } \\
\text { simvastatīns). }\end{array}$ \\
\hline
\end{tabular}

PD - piesātinošā deva, UD - uzturošā deva, NPL - nesterō̄die pretiekaisuma līdzekḷi.

Pēdējo gadu laikā vairāki pētījumi pierādījuši prasugrela efektivitāti, salīdzinot ar klopidogrelu. Randomizētā, dubultaklā, divfāzu pētījumā (PRINCIPLE-TIMI 44 - Prasugrel in Comparison to Clopidogrel for Inhibition of Platelet Activation and Aggregation-Thrombolysis in Myocardial Infarction 44) salīdzināja terapijas efektivitāti pacientiem ar prasugrela standarta devām un klopidogrela palielinātām devām. Trombocītu agregācijas inhibīcija sešas stundas pēc antiagreganta PD saņemšanas 
(60 mg prasugrela vai $600 \mathrm{mg}$ klopidogrela) pacientiem ar plāna PCI bija statistiski ticami augstāka prasugrela gadījumā, salīdzinot ar klopidogrelu (attiecīgi, vidējais $\pm S D$, $74,8 \pm 13,0 \%$ vs $31,8 \pm 21,1 \%, \mathrm{p}<0,0001)$. Analizējot ilgtermiņa terapijas efektu pēc 28 dienām ar UD prasugrelam $10 \mathrm{mg}$ / dienā un klopidogrelam $150 \mathrm{mg} /$ dienā, trombocītu agregācijas inhibīcija saglabāja iepriekšminēto tendenci $(61,3 \pm 17,8$ vs $46,1 \pm 21,3 \%$, p<0,0001). Šì pêtījuma dati pierādīja, ka prasugrela UD un PD ir efektīvāka nekā klopidogrela terapija paaugstinātās devās. Autori secināja, ka prasugrelam kā trešās paaudzes tienopiridīnu grupas līdzeklim raksturīga lielāka trombocìtu inhibīcijas spēja ar mazāku interindividuālo variabilitāti, salīdzinot ar klopidogrela terapiju [Wiviott et al., 2007].

Wiviott et al. pētîjumā, kur tika iekḷauti 13608 pacienti ar AKS, kuriem indicēta PCI veikšana, salīdzināja prasugrela (60 mg PD un 10 mg UD) un klopidogrela (300 mg PD un 75 mg UD) terapijas efektivitāti ilgtermiņā (6-15 mēneši). Kā primārie efektivitātes - riska rādītāji tika izvirzīti sekojoši nelabvēlīgie KV notikumi: nāve KV cēloṇa dēḷ, nefatāls MI un CI. Kā terapijas drošības rādītājs tika vērtēta asiņošanas attīstība. Pētījumā secināja, ka nelabvēlīgie KV notikumi biežāk novēroti klopidogrela lietotāju grupāa, salīdzinot ar prasugrela grupu $(12,1 \%$ vs $9,9 \%$, HR prasugrels vs klopidogrels 0,$81 ; 95 \%$ CI, 0,73-0,90, p<0,001). Tomēr asingošanas attīstības tendences bija pretējas - asiņošanu biežāk novēroja prasugrela lietotājiem $(2,4 \%)$, salīdzinot ar klopidogrelu $(1,8 \%, p=0,03)$, tajā skaitā arī dzīvību apdraudoša asiņošana (nefatāla un fatāla) prasugrela grupā bija biežāk $(1,4 \%$ vs $0,9 \%, p=0,01)$. Pētījuma rezultāti liecina, ka AKS pacientiem ar plāna PCI prasugrela terapija nodrošina samazinātu išēmisko notikumu attīstību, vienlaicīgi palielinot asiņošanas risku [Wiviott et al., 2007]. Līdz ar to īpaši būtiski ir katra pacienta individuālā ieguvuma - riska attiecības noteikšana, lai izvēlētos konkrētam pacientam vispiemērotāko antiagregantu terapiju [Ivandic et al., 2011]. 


\section{DARBA METODES}

\subsection{Pētījuma izpildīšanas vieta}

Pētījums veikts Paula Stradiṇa Klīniskās universitātes slimnīcas (PSKUS) Latvijas Kardioloǵijas centrā (LKC) un Latvijas Kardioloǵijas zinātniskā institūtā sadarbībā ar Latvijas Biomedicīnas pētîjumu un studiju centru (BMC) un PSKUS Šūnu transplantācijas centru.

\subsection{Pētījuma dizains un kopējās pacientu grupas atlases principi}

Prospektīvā pētījumā tika izmantoti LKC stacionēto pacientu dati, kuriem tika nozīmēta klopidogrela terapija trombožu profilaksei pēc DES stenta implantācijas un pēc AKS. Pētījumu apstiprināja PSKUS Attīstības biedrības Klīniskās izpētes ètikas komiteja (atzinums Nr. 300610 - 2L, 2010. gada 30. jūnijs).

\section{Iekḷaušanas kritēriji:}

- Pacientam stacionēšanas reizē veikta PCI ar vismaz viena DES stenta implantāciju.

- Pacients ne ilgāk kā pirms 24 stundām saņēmis klopidogrela 300 mg vai 600 mg PD.

- Pacients rakstiski piekrīt piedalīties pētījumā, atkārtotai asins paraugu nodošanai, piekrīt ierasties uz FUP vizītēm un telefoniskām intervijām.

\section{Izslēgšanas kritēriji:}

- Pacients nevēlas piedalīties vai sagaidāma slikta līdzestība.

- Hroniska sirds mazspēja (HSM) IV funkcionālā klase pēc NYHA.

- Aktīva asiņošana vai hemorāgiskāa diatēze. Zināma trombocitopātija. Trombocītu skaits zem 100 000/. $\mathrm{mm}^{3}$.

- Perorālo antikoagulantu terapija.

- Zināma smaga aknu patologija (ciroze, hronisks hepatîts) vai kopējā bilirubīna koncentrācija asins serumā $>2 \mathrm{mg} / \mathrm{dl}(>34,2 \mu \mathrm{mol} / \mathrm{l})$.

- Jebkurš hemorāgisks vai neprecizētas ǵenēzes CI. 
- Malignitāte un citas nopietnas patoloǵijas ar sagaidāmo dzīvildzi zem 1 gada.

- Zināma alergijija pret pētījumā izmantojamiem medikamentiem.

\subsection{Datu iegūšanas metodes}

\subsubsection{Apkopotā informācija par fenotipu}

Informācija par katru pētījumā iesaistīto pacientu pēc personas rakstiskas piekrišanas tika ierakstīta speciāli izstrādātā pētījuma anketā, kurai piešķirts speciāls kods. Informācija par pacienta identitāti (koda atšifrējums) un anketas glabājas tikai LKC un netiek nodotas tālāk. Par visiem pacientiem tika iegūta fenotipiskā informācija, kā arī veiktas laboratoriskās un ǵenētisko polimorfismu analīzes. Par katru pacientu tika reǵistrēti konvencionālie riska faktori: vecums, dzimums, informācija par smēķēšanas statusu (nesmēķētājs, aktīvs vai izbijis smēķētājs, ja atmetis pirms $>1$ mēneša, cik ilgi nesmēķē (< vai > 1 gadu)), AH (pakāpe, ilgums). Īpaša rūpīgi tika apkopoti dati par ST riska faktoriem: CD un tā tipu, CI un tā tipu, HSM un tās klasi, sirds kreisā kambara (KK) izsviedes frakciju (EF - ejection fraction), malignitāti, hronisku nieru slimību (HNS). Ievākti arī KSS anamnēzes dati: vai ir bijuši MI, to skaits, laiks kopš pēdējā MI (1 mēneša vai 1 gada laikā). MI diagnoze tika atzīmēta, ja tāda tika minēta iepriekšējos slimnīcu izrakstos. Tika apkopota informācija arī par revaskularizāciju anamnēzē (PCI skaits, ievietoto stentu skaits un veids, labotā artērija), koronāro artēriju šuntēšanas (CABG) reižu skaits, tips, balstoties uz iepriekšējo izrakstu datiem.

Lai uzlabot datu ticamību, katrā atbildē uz jautājumiem tika īpaši atzīmēts, ja informācija nebija pārliecinoša. Apkopoti dati par farmakoterapiju (klopidogrels (deva, lietošanas ilgums), aspirīns (deva, lietošanas ilgums), citi NPL, statīni, angiotenzīnu konvertējošā enzīma inhibitori (AKEI), angiotenzīna II receptoru blokatori (A2RB), beta blokatori (BB), KKB, nitrāti, antiaritmiskie līdzekḷi, PSI (tips, deva), antibakteriālie līdzekḷi, līdekḷi CD terapijai), ko pacients bija lietojis regulāri pēdējās nedēḷas laikā, kā arī stacionārā nozīmētā terapija. Pacientam noteica svaru un augumu, aprēksināja ĶMI.

No laboratoriskiem raksturlielumiem serumā tika noteikts lipīdu (kopējā holesterīna $(\mathrm{KH})$, augsta blīvuma lipoproteīnu holesterīna (ABLH), zema blīvuma lipoproteīnu holesterīna (ZBLH), triglicerīdu (TG)), glikozes līmenis, aknu funkcionālie marķieri: alanīnaminotransferāze (ALAT), aspartātaminotransferāze (ASAT), kopējais 
bilirubīns, kreatinīns, $\mathrm{C}$ reaktīvais olbaltums (CRO). Citrētā plazmā tika noteikts fibrinogēna līmenis, aktivētais parciālais tromboplastīna laiks (APTL), starptautiska normalizēta protrombīna laika attiecība (INR), kardioloǵiskie marķieri: troponīns I un kreatīnkināzes MB frakcija (CK-MB). Asins paraugā etilēndiamīntetraacetāta (EDTA) klātbūtnē - hemoglobīns, hematokrīts un asins šūnu (eritrocītu, leikocītu, trombocītu) skaits, vidējais eritrocītu un trombocītu tilpums, eritrocītu grimšanas ātrums.

Vakutaineros ar EDTA tika ņemti arī pacientu plazmas paraugi, kas tūlìt pēc separācijas ar centrifūgu tika sasaldēti un glabāti $-70{ }^{\circ} \mathrm{C}$ temperatūrā. Šādā temperaturā tika glabāti arī pacientu urīna paraugi.

Pēc 40 dienām tika veikta pacientu FUP vizīte, kuras laikā tika veikta atkārtota VASP fosforilācijas analīze, nosakot PRI, kā arī reǵistrēti dati par stacionēšanu pēdējo piecu nedēlu laikā (skaits, iemesls), balstoties uz slimnīcu izrakstu datiem, asiņošanas novērošanu, atzīmēta farmakoterapija.

Telefonintervijas tika nodrošinātas šādos termiṇos kopš iekḷaušanas brīža 3 mēneši, 6 mēneši, 1 gads.

\subsection{2. Ģ̣enētiskās analīzes}

Visi pacienti pēc piekrišanas saņemšanas tika iekḷauti Latvijas Genomu datu bāzē, kam ir saṇemta Ētikas komisijas atļauja (atbildīgais Dr. biol. J. Kloviņ̌s). Ģenētiskām analīzēm domātie asiņu paraugi (divi stobriņi ar EDTA (10ml, BD Vacutainer, Franklin Lakes, NJ, ASV) un viens SST stobrinšs (BD Vacutainer SST $T^{T M}$ Gel Separator Tube, 5ml, BD Vacutainer, Franklin Lakes, NJ, ASV) tika marķēti ar pacienta kodu un nogādāti Latvijas BMC. Personāls, kurš veica dezoksiribonukleīnskābes (DNS) analīzes, nezināja klīnisko informāciju par slimniekiem. DNS izdalīšana tika veikta pēc standarta fenola-izopropanola metodes. Tika noteikti septiņi polimorfismi: $C Y P 2 C 19 * 2, C Y P 2 C 19 * 3, C Y P 2 C 19 * 5, C Y P 2 C 19 * 17, C Y P 2 C 9 * 2$, $C Y P 2 C 9 * 3, A B C B 1$, kuru kārtas numuri Nacionālajā Biotehnoloǵiju Informācijas centra SNP (single-nucleotide polymorphism) datubāzē (bdSNP) ir attiecīgi rs4244285, rs4986893, rs56337013, rs12248560, rs1799853, rs1057910, rs1045642. DNS paraugi tika ievietoti 96 bedrīšu polimerāzes ķēdes reakcijas (angl. polymerase chain reaction PCR) platēs, izmantojot daudzkanālu pipetes (Tecan Freedom Evo system, Tecan, Mannedorf, Switzerland) ar maināmiem filtru saturošiem uzgaļiem. DNS koncentrācija tika normalizēta līdz 7ng/ $\mu \mathrm{L}$. Genotipēšana tika veikta ar Applied Biosystems TaqMan 
SNP Genotyping Assay, izmantots Vii7 Real-Time PCR system (Life Technologies). Paraugu genotipu signālu reǵistrēšana tika veikta ar AutoCaller 1.1 (Applied Biosystems) programmu.

\subsubsection{Klopidogrela rezistences analīze}

Rezistences izvērtēšanai tika izmantots asins plūsmas citometrs "Cytomics FC-500" (Beckman Coulter FC Flow Cytometer Series, Beckman Coulter, Miami, Florida, ASV). Klopidogrela rezistence definēta kā PRI $\geq 60 \%$ pēc pirmās klopidogrela PD 300 mg (plānveida PCI ar DES) vai 600 mg (primāra vai akūta PCI ar DES) saņemšanas. Pētījuma gaitā pacientiem tika noteikta trombocītu reaktivitāte, izmantojot VASP testu (PLT VASP/P2Y12) - stacionārā (1-4 reizes), ambulatori - pēc 10 (ja konstatēta klopidogrela samazināta efektivitāte) un pēc 40 dienām (skat. 2.1. attēlu).

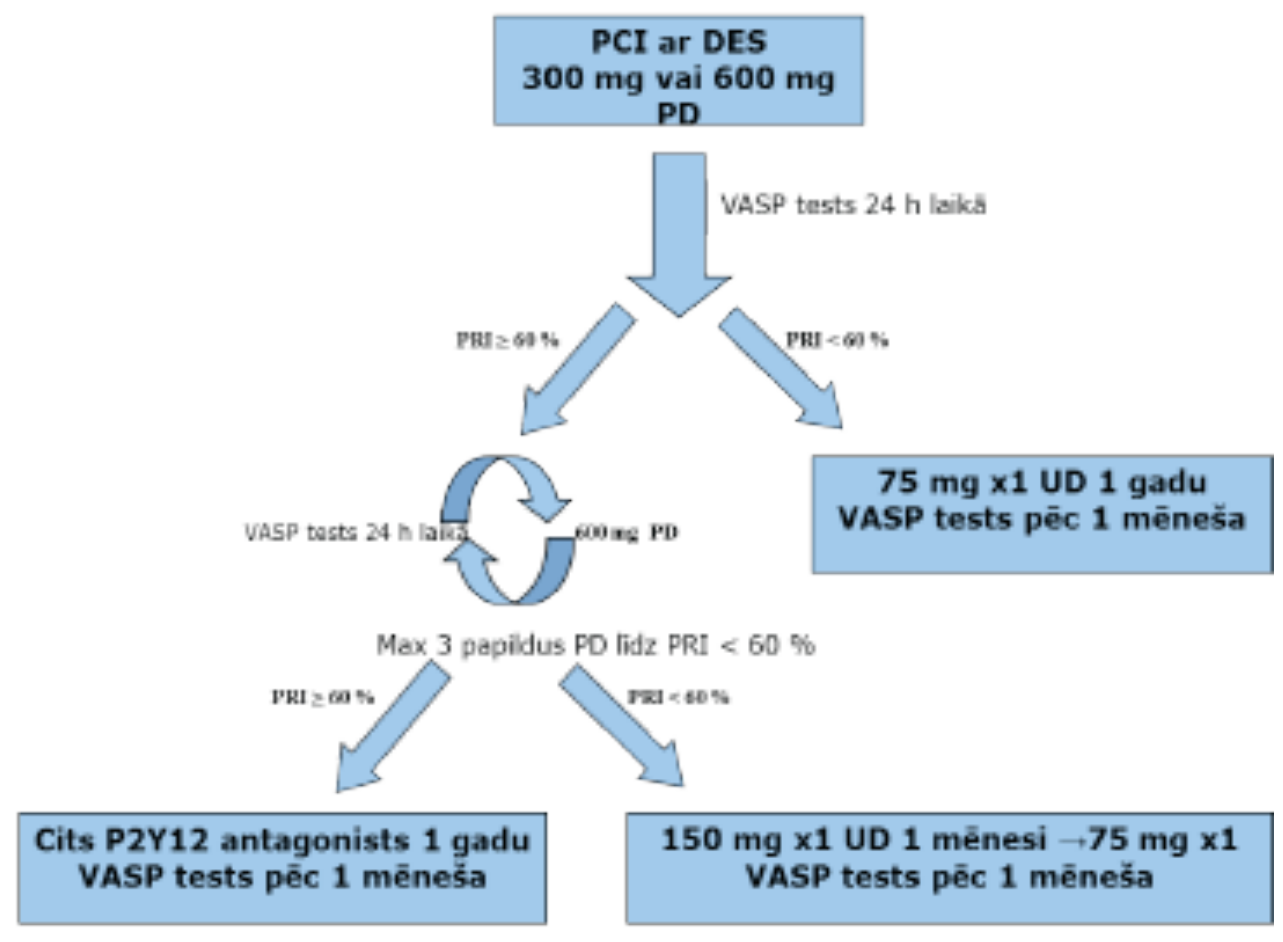

Telefona intervijas pẻc $3,6,12$ un 24 mēnešiem

\section{1. att. Pētījuma dizains}

PCI - perkutāna koronāra intervence, PRI - trombocītu reaktivitātes indekss, VASP vazodilatatorstimulējošais fosfoproteīns, PD - piesātinošā deva, UD - uzturošā deva. 
VASP fosforilācijas analīze, nosakot PRI, tika veikta 24 stundu laikā pēc klopidogrela PD saņemšanas. Ja PRI bija $\geq 60 \%$, tad pacients saņēma papildu līdz 3 PD (3 × $600 \mathrm{mg})$, ar mērķi iegūt PRI <60\%. Ja šo mērķi neizdevās sasniegt ar papildu PD, tad pacientam tika nozīmēta klopidogrela terapija $150 \mathrm{mg} /$ dienā pirmo mēnesi, turpinot ar standarta UD (75 mg / dienā), VASP fosforilācijas analīze pēc 10 un pēc 40 dienām. Ja ar šīm papildu PD PRI saglabājās $\geq 60 \%$, tad pacientam tika nozīmēta cita antiagreganta (tikagrelors) terapija, PRI kontrole pēc 40 dienām. Ja PRI $<60 \%$ jau pirmās analīzes laikā, tad pacients saņēma klopidogrela standarta UD (75 mg / dienā), VASP fosforilācijas analīze pēc 40 dienām.

Analīzes veikšanai tika izmantoti vairāki reaǵenti (ADF, PGE1, anti-VASP peles monoklonālā antiviela). VASP fosforilācija (VASP-P) ir atkarīga no trombocītu P2 $\mathrm{Y}_{12}$ receptoru aktivācijas līmeņa, kas ir mērķis klopidogrela darbībai. VASP fosforilācija tiek regulēta ar cAMF kaskādes tipa reakciju palīdzību. PGE1 šīs reakcijas aktivē, turpretī ADF bloksē, iedarbojoties uz trombocītu $\mathrm{P}_{12} \mathrm{Y}_{12}$ receptoriem. PRI, izteikts procentuālā izteiksmē, raksturo VASP fluorescences intensitātes atšķirību starp trombocītiem, iedarbojoties ar PGE1 vai PGE1 un ADF vienlaicīgi. Zināms, ka PRI korelē ar trombocītu agregācijas inhibīciju, ko izraisījusi P2Y 12 receptoru blokāde. Pētījumos biežāk minētā robežvērtība atbilstošai reakcijai uz klopidogrela terapiju ir tādā gadījumā, ja PRI $<50 \%$, bet neadekvātai - PRI >50\% [Varenhorst et al., 2009, Bonello et al., 2008, Pampuch et al., 2006].

\section{Darbības princips un ietekmējošie faktori}

Plūsmas citometrija balstās uz specifisku antivielu saistī̌sanos ar attiecīgo šūnu receptoriem. Šīs antivielas ir konjugētas ar fluorohromu, kas fluoriscē pie noteikta viḷna garuma, kad tiek ierosināts. Dati tiek nolasīti un pārveidoti digitālā veidā, attēlojot tos CXP programmā. Ar antivielām saistītie fluorohromi ir jūtīgi pret gaismu, tāpēc jāseko ražotāja norādījumiem un inkubēšanas reakcijas jāveic tumsā.

\section{VASP fosforilācijas analīzes teorētiskais pamatojums, izmantojot asins plūsmas citometru}

PLT VASP/P2Y12 kits ir paredzēts specifiskai trombocītu ADF receptoru $\left(\mathrm{P} 2 \mathrm{RY}_{12}\right)$ antagonistu efektivitātes konstatēšanai. VASP ir intracelulārais trombocītu proteīns, kas normā sastopams nefosforilētā stāvoklī. VASP fosforilācija tiek regulēta ar 
cAMP kaskādes tipa reakciju. PGE1 aktivē šo reakciju, bet ADF caur P2 $\mathrm{Y}_{12}$ receptoriem inhibē šo kaskādi (skat. 2.2. attēlu).

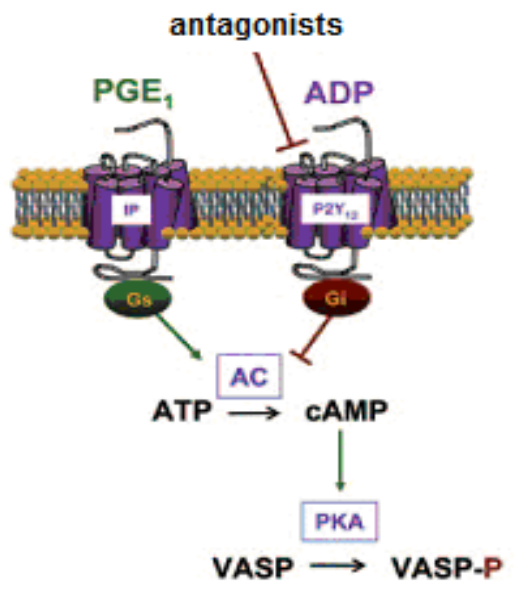

\section{2.att. Intracelulārā trombocītu proteīna (VASP) fosforilācijas mehānisms [Michelson, 2008]}

PGE1 - prostaglandīns E1, ADP - adenozīna difosfāts, AC - adenilciklāze, ATP - adenozīna trifosfāts, cAMP - cikliskais adenozīna monofosfāts, PKA - proteīnkināze A, VASP vazodilatatorstimulējošais fosfoproteīns, VASP-P - vazodilatatorstimulējošā fosfoproteīna fosforilācijas pakāpe.

Veicot testu, VASP-P korelē ar P2Y $_{12}$ receptoru inhibīcijas pakāpi, savukārt VASP nefosforilētais stāvoklis korelē ar $\mathrm{P}_{2} \mathrm{Y}_{12}$ receptoru aktīvo formu.

Tienopiridīnu grupas medikamentu interindividuālā variabilitāte un rezistence tiek plaši pētīta. Šīs grupas medikamentu efekts var tikt pārbaudīts ar PLT VASP/P2Y 12 , nosakot VASP-P pakāpi, paraugus apstrādājot ar PGE1 vai ar PGE1 un ADF vienlaicīgi.

Lai gan asins plūsmas citometrs pagaidām nepieder pie analīzes metodēm, ko izmanto ikdienas praksē, bet tas ir bieži sastopams literatūrā, lai definētu medikamentu rezistenci [Pampuch et al., 2006]. VASP noteikšana pieder pie bioksīmisko testu metodēm, mērot antiagregantu inhibīcijas aktivitāti (klopidogrela gadījumā).

VASP līmenis ir marķieris trombocītu $\mathrm{P}_{2} \mathrm{Y}_{12}$ receptoru aktivitātei, kas savukārt liecina par klopidogrela izraisīto inhibīcijas pakāpi. VASP ir nozīmīga loma GP receptoru IIb/IIIa aktīvās formas izveidē. Fosforilētā VASP forma ir neaktīva. Piesaistoties $\mathrm{P}_{2} \mathrm{Y}_{12}$ trombocītu receptoram, ADF nodod intracelulāro signālu, kas nomāc fosforilētās VASP formas veidošanos. ADF inhibīcija ar klopidogrelu sekmē 
VASP pārveidi fosforilētā formā [Williams et al., 2009]. PGE1 palielina VASP fosforilācijas līmeni, stimulējot adenilciklāzi. ADF piesaistīšanās pie $\mathrm{P} 2 \mathrm{Y}_{12}$ receptoriem caur Gi izraisa adenilciklāzes inhibīciju. Tādējādi papildus pievienojot ADF pie ar PGE1 stimulētiem trombocītiem samazinās PGE1 izraisītas VASP fosforilācijas apjoms [Papathanasiou et al., 2007, Michelson, 2008].

Ja $\mathrm{P}_{2} \mathrm{Y}_{12}$ receptori tiek veiksmīgi inhibēti ar klopidogrelu, pēc ADF papildu pievienošanas nesamazinās PGE1 stimulētais VASP fosforilācijas līmenis. Šis princips tiek izmantots metodes pamatā, kur fosforilētais VASP tiek iezīmēts ar monoklonālām antivielām.

$\mathrm{P}_{12} \mathrm{Y}_{12}$ receptoru aktivitāte tiek aprēķināta, nosakot vidējo fluorescences intensitāti (MFI) paraugos ar PGE1 un PGE1+ADF [Cayla et al., 2008, Aleil et al., 2005]. Plūsmas citometra izmantošana ir dārga metode, bet tajā pašā laikā raksturo trombocītu aktivācijas specifisku cel̦u caur $\mathrm{P}_{2} \mathrm{Y}_{12}$ receptoriem, kurus inhibē klopidogrels, līdz ar to samērā specifiska trombocītu agregācijas analīze [Kuliczkowski et al., 2009].

\section{Metodes raksturojums}

Asins paraugs tiek inkubēts ar PGE1 vai ar PGE1 un ADF. Pēc šūnu permeabilizācijas fosforilētais VASP tiek iezīmēts ar netiešo imunofluorescences metodi, izmantojot specifisku monoklonālo antivielu (16C2). Duāla krāsu plūsmas citometra analīze ḷauj salīdzināt rādītāju divos testēšanas apstākḷos un palielināt katra parauga ADF kapacitāti, inhibējot VASP fosforilāciju.

PRI tiek matemātiski aprēķināts, izmantojot iegūto MFI, inkubējot tikai ar PGE1 vai vienlaicīgi kopā ar ADPF.

VASP fosforilācijas analīze tika veikta, izmantojot PLT VASP/P2Y 12 reaǵentu komplektu (BIOCYTEX, Francija).

Reaǵenti:

Reaǵents 1 - šķīidinātājs, 60 ml;

Reaǵents $2 \mathrm{a}-\mathrm{PGE1}$;

Reaǵents $2 b-\mathrm{PGE} 1+\mathrm{ADF}$;

Reaǵents 3 - fiksators; 
Reaǵents $4 \mathrm{a}$ - anti VASP-P peles monoklonālā antiviela + permeabilizācijas aǵents;

Reaǵnets $4 b$ - negatīvā izotopu kontrole (peles monoklonālā antiviela) + permeabilizācijas aǵents;

Reaǵents 5 - reaǵents iezīmēšanai (iekrāsošanai), poliklonāla antiviela pret peles IgG-FITC + iezīmēto trombocītu skaitītājs.

\section{Papildu nepieciešamie materiāli}

1. Maisītājs (vortex);

2. Hronometrs;

3. Citometrs;

4. Atbilstošas pipetes $(10 \mu \mathrm{l}, 1 \mathrm{un} 2 \mathrm{ml})$;

5. Hemolīzes caurulītes citometram;

6. Destilēts, dejonizēts vai injekciju ūdens.

\section{Reaǵentu sagatavošana un uzglabāšana}

Neatvērtu analīžu kitu sastāvs ir nemainīgs līdz uz iepakojuma norādītajam derīguma termiņa beigām, uzglabājot $2-8^{\circ} \mathrm{C}$ temperatūrā. Nedrīkst sasaldēt! Reaǵenti 1, 3, 4a, 4b un 5 - gatavi lietošanai, pēc atvēršanas stabilitāte saglabājas 2 mēnešus temperatūrā $2-8^{\circ} \mathrm{C}$. Reaǵenti $2 \mathrm{a}$ un $2 \mathrm{~b}$ - pirms lietošanas jāatšksaida ar $400 \mu l$ destilēta ūdens un jāveic homogenizācija, izmantojot maisītāju 5 sekundes. Pēc šādas sagataves reaǵenti derīgi 1 mēnesi temperatūrā $2-8^{\circ} \mathrm{C}$.

\section{Asins parauga iegūšana PRI noteikšanai}

Darbam tika izmantotas perifērās venozās asinis. Ne vēlāk kā 24 stundas pēc klopidogrela PD saņemšanas asins paraugus savāca sertificēta medmāsa saskaņā ar sterilitātes noteikumiem, veicot jaunu vēnas punkciju, izmantojot vienreizējās lietošanas adatas un rezervuārus. Pirmie vismaz $5 \mathrm{ml}$ asinu tika eliminēti, nākamos $5 \mathrm{ml}$ savācot plastikāta stobriņā ar 0,109M nātrija citrāta šķ̄īumu (BD Vacutainer, Franklin Lakes, NJ, ASV). Stobriņi ar asins paraugu līdz testēšanas sākumam aizvērtā veidā tika uzglabāti istabas temperatūrā $\left(18-25^{\circ} \mathrm{C}\right)$. Asins paraugu analīzes rekomendēts veikt 
48 stundu laikā pēc parauga paṇemšanas. Šajā pêtījumā mēs pieturējāmies pie 12 stundu robežas.

\section{Paraugu sagatavošanas procedūra}

Paraugi analīzei tika sagatavoti atbilstoši ražotāja instrukcijām, paralēli veicot negatīvās kontroles. Ievērojot standarta laboratorijas prakses principus, no pacienta asins parauga ar mikropipeti, izmantojot maināmus uzgaḷus ar filtriem, trīs plastikāta stobriņos ievadīti $10 \mu \mathrm{l}$ asiņu. Stobriņi marķēti ar pacienta kodu un kārtas numuriem T1, T2, T3.

1. Paraugu sagatavošanas sākumposms:

- $\quad$ T1 pievieno $10 \mu 1$ PGE1 šksīduma;

- $\quad$ T2 un T3 pievieno 10 $\mu 1$ PGE1+ADF šķīduma;

- stobriņus 1-2 sekundes homogenizē ar maisītāju, izmantojot mazu ātrumu;

- inkubē paraugus 10 minūtes istabas temperatūrā.

2. Fiksācija:

- visiem stobriņiem pievieno $10 \mu 1$ paraformaldehīda šķ̄īuma;

- stobriņus 1-2 sekundes homogenizē ar maisītāju;

- inkubē paraugus 5 minūtes istabas temperatūrā.

3. Šūnu membrānas permeabilizācija un imunoiezīmēšana:

- $\quad$ T1 un T2 pievieno $10 \mu 1$ šķīdumu ar monoklonālajām peļu anti-VASP-P antivielām un šūnu membrānu permeabilizācijas aǵentu;

- T3 pievieno $10 \mu$ l šksīdumu ar negatīvām izotipiskām kontroles antivielām (monoklonālās peḷu antivielas) un šūnu permeabilizācijas aǵentu;

- stobriņus 1-2 sekundes homogenizē ar maisītāju;

- inkubē paraugus 5 minūtes istabas temperatūrā. 
4. Iezīmēšana ar flourescentu aǵentu:

- Visiem stobriniem pievieno $10 \mu 1$ šks̄īduma ar poliklonālām anti-peļu IgG-FITC (fluorescīna izotiocianāta) iezīmētām antivielām, trombocītus iezīmējošām anti-CD61-PE (fikoeritrīna) antivielām, kā arī šūnu membrānu permeabilizācijas aǵentu;

- stobriņus 1-2 sekundes homogenizē ar maisītāju;

- inkubē 5 minūtes istabas temperatūrā.

5. Šķīinātāja pievienošana:

- Visiem stobriņiem pievieno $2 \mathrm{ml}$ šķīināâāja;

- stobrinuus 1-2 sekundes homogenizē ar maisītāju;

- inkubē 5 minūtes istabas temperatūrā.

Ja šādi sagatavoti paraugi netika analizēti uzreiz, atbilstoši instrukcijām tos uzglabāja $2-8^{\circ} \mathrm{C}$ temperatūrā ne ilgāk par 2 stundām.

\section{Analīze ar plūsmas citometru}

Paralēli paraugu sagatavošanai, tika sagatavots darbam arī plūsmas citometrs (Beckman Coulter FC Flow Cytometer Series, Beckman Coulter, Miami, Florida, ASV), veikta plūsmas citometra kvalitātes kontrole pēc noteikta protokola. Apstarojot paraugus ar argona lāzera stariem, no ar flourohromu FITC un PE iezīmētajām antivielām ieguva starojumu attiecīgi $495-521 \mathrm{~nm}$ un 565-585nm frekvences diapazonā. FITC fluorohromu starojuma intensitāte korelē ar VASP-P koncentrāciju paraugā. T1 stobriņā, kam pievienots PGE1, fluorescence ir visaugstākā. T2 sagaidāma zemāka fluorescence, jo tika pievienots gan PGE1, gan ADF, kas inhibē VASP-P veidošanos. T3 stobriņš bija kontrole, tajā novērota viszemākā fluorescences intensitāte, jo tam papildu pievienotas negatīvās izotopiskās kontroles antivielas.

Katra pacienta parauga analīze tika veikta piecas reizes, katru reizi nosakot PRI, kā gala rezultātu aprēķinot vidējo rādītāju: $\mathrm{PRI}_{\text {vid }}=\left(\mathrm{PRI}_{1}+\mathrm{PRI}_{2}+\mathrm{PRI}_{3}+\mathrm{PRI}_{4}+\mathrm{PRI}_{5}\right) / 5$. 


\section{Iegūto rezultātu interpretācija}

PRI tika aprēķināts, izmantojot vidējās fluorescenes intensitāti (MFI - angl. mean fluorescence intensity). Precīzu datu iegūšanai izmantoti koriḡēti MFI $\left(\mathrm{MFI}_{\mathrm{c}}-\right.$ angl. mean fluorescence intensity corrected), ko aprēksināja no T1 (ar PGE 1 ) un T2 $\left(\mathrm{PGE}_{1}+\mathrm{ADP}\right)$ atņemot $\mathrm{T} 3 \mathrm{MFI} . \mathrm{MFI}_{\mathrm{c}} \mathrm{T} 1$ un $\mathrm{T} 2$ stobriņiem aprēķina pēc formulas: $\mathrm{MFI}_{\mathrm{c}(\mathrm{PGE} 1)}=\mathrm{MFI}_{\mathrm{c}(\mathrm{T} 1)}=\mathrm{MFI}_{(\mathrm{T} 1)}-\mathrm{MFI}_{(\mathrm{T} 3) ;} \mathrm{MFI}_{\mathrm{c}(\mathrm{PGE} 1+\mathrm{ADP})}=\mathrm{MFI}_{\mathrm{c}(\mathrm{T} 2)}=\mathrm{MFI}_{(\mathrm{T} 2)}-\mathrm{MFI}_{(\mathrm{T} 3)}$. PRI aprēķināja pēc šādas formulas: PRI $=\left(\mathrm{MFIc}_{\mathrm{PGE} 1}-\mathrm{MFIc}(\mathrm{PGE1}+\mathrm{ADP}) / \mathrm{MFI}_{\mathrm{c}} \mathrm{PGE}_{1}\right) \times$ 100 .

PRI būtībā parāda, par cik procentiem ADF spēj samazināt maksimālo VASP-P koncentrāciju trombocītā.

VASP analīzei ar plūsmas citometra palīdzību ir būtiska priekšrocība, salīdzinot ar citām analīzes metodēm. Jau iepriekš minēts, ka VerifyNow kitus klopidogrela noteikšanai nevar izmantot pacientu analīzei, kas pēdējo 48 stundu laikā saṇēmuši GP IIb/IIIa receptoru antagonistus (piemēram, tirofibāns, eptifibatīds) vai pēdējo 14 dienu laikā abciksimabu. Iemesls šim metodes trūkumam ir fibrinogēna saistī̌sanās pie GP IIb/IIIa receptoriem, kas ir pēdējais agregācijas posms, līdz ar to GP IIb / IIIa receptoru antagonistu klātbūtne var izraisīt mijiedarbību ar klopidogrela analīzei paredzēto kitu sastāvu [Williams et al., 2009].

\subsubsection{Datu statistiskās apstrādes metodes}

Datu statistiskā apstrāde tika veikta ar SPSS programmu (IBM SPSS Statistics Version 17, SPSS inc., ASV). Par statistiski ticamiem rezultātiem tika uzskatīti dati ar $\mathrm{p}$ vērtību $<0,05$. Kvantitatīvie mainīgie tika aprakstīti ar aritmētisko vidējo un standartdeviāciju (SD). Gadījumos, kad sadalījums krasi atšķīrās no normālā, tika aprēksināta mediānā vērtība un standartkḷūda vai starpkvartiļu intervāls. Kategoriskie jeb kvalitatīvie main̄̄gie tika raksturoti kā skaits un procentuāla proporcija. Mainīgie, kuru dispersija krasi atšķīrās no normālās, tika transformēti, tuvinot dispersiju normālai, un tālākos aprēķinos tika izmantotas tikai transformētās vērtības. Normāli sadalīto kvantitatīvo mainīgo salīdzinājumi tika veikti ar Stjūdenta t-testu starp divām grupām vai ANOVA metodi starp trīs un vairāk grupām. Saistība starp diviem kvantitatīvajiem mainīgajiem, kā arī starp ǵenētisko variāciju grupām un kvantitatīvo mainīgo tika analizēta ar lineārās regresijas metodi. Kategoriskie main̄̄gie tika salīdzināti ar Pīrsona (Pearson) $\chi^{2}$ testu vai Fišera (Fisher) eksakto testu atbilstoši testu lietošanas 
nosacījumiem. Ģenētisko faktoru ietekmes analīzei tika veiktas daudzmain̄̄gās analīzes. Kvantitatīvo main̄̄go analīzei tika izmantota multiplā lineārā regresija un ANCOVA metode. Kategoriskie mainīgie tika analizēti ar logistiskās regresijas analīzi.

Novēroto genotipu atbilstība Hārdija-Veinberga līdzsvaram tika pārbaudīta ar $\chi^{2}$ atbilstības testu (Chi-square Goodness of Fit test), salīdzinot novēroto un sagaidāmo genotipu biežumu. Sagaidāmais genotipu biežums tika aprēķināts pēc novēroto alēḷu biežuma un to kombināciju varbūtības, lietojot formulu: $(p \times q)^{2}=p^{2}+2 p q+q^{2}$, kur p - izplatītākās alēles sastopamības biežums, q - retākās alēles sastopamības biežums, pp, pq, qq - abu alēļu kombinācijas, kas veido attiecīgos genotipus. 


\section{REZULTĀTI}

\subsection{Pacientu vispārējs raksturojums}

Laika posmā no 2010. gada septembra līdz 2012. gada decembrim notika PSKUS LKC stacionēto pacientu iekḷaušana pētījumā atbilstoši pētījuma iekḷaušanas un izslēgšanas kritērijiem. Šajā laika posmā pētījumā iekḷauti 118 pacienti, no kuriem pēc pētījuma protokola atbilst 94 pacienti, kas izmantoti tālākai pētījuma rezultātu analīzei. No pētījuma tika izslēgti 24 pacienti, jo neatbilda pētījuma protokolam dažādu iemeslu dẹl, piemēram, nelietoja klopidogrelu paredzētajā devā $(n=12)$, ārstējošais ārsts nomainīja terapiju uz citu antiagregantu $(n=8)$, atteicās no dalības pētījumā pēc sākotnējas piekrišans vai neieradās uz paredzētajām apsekojuma vizìtēm (n=4).

Pētījuma personu kopas fenotipiskais raksturojums (demogrāfiskie un riska faktori, laboratoriskie raksturlielumi un prehospitālā terapija) apkopots 3.1. tabulā. No pētījuma pacientiem lielākā daļa (75 pacienti; 79,8\%) tika stacionēti plāna kārtā un tikai 19 pacienti (20,2\%) akūtā kārtā PCI ar DES veikšanai. Pētījuma populācijā bija


81 gadiem. Izmantojot neatkarīgo izlašu t-testu, tika secināts, ka vidējais vecums starp

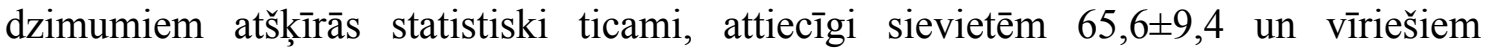
$60,7 \pm 9,4(\mathrm{t}=2,504 ; \mathrm{p}=0,014)$. Vidējais ĶMI pacientiem bija $29,7 \pm 4,6 \mathrm{~kg} / \mathrm{m}^{2}$ un tas statistiski ticami neatšķīīās starp dzimumiem, attiecīgi sievietēm $29,8 \pm 4,8 \mathrm{~kg} / \mathrm{m}^{2}$ un

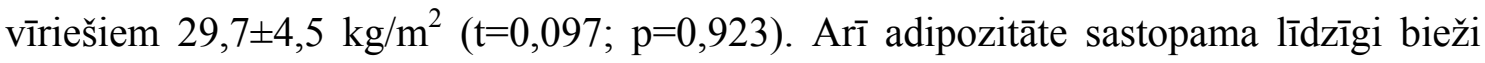
starp abiem dzimumiem, attiecīgi 20 sievietēm (45,5\%) un 20 vīriešiem (40,0\%)



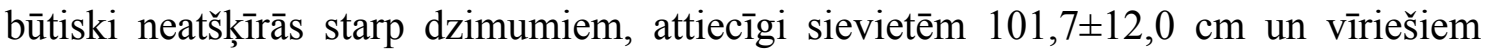
$105,2 \pm 10,1 \mathrm{~cm}(\mathrm{t}=1,521 ; \mathrm{p}=0,132) . \mathrm{CD}$ bija 28 (29,8\%) pacientiem. Stacionēšanas brīd̄̄ aspirīnu lietoja $71(75,5 \%)$ pacients, klopidogrela terapiju saņēma $6(6,4 \%)$ pacienti. 


\begin{tabular}{|c|c|}
\hline Parametrs & \\
\hline Vecums (gadi), vidējais \pm SD & $63,0 \pm 9,7$ \\
\hline Dzimums - vīrieši, n (\%) & $50(53,2)$ \\
\hline ĶMI $\left(\mathrm{kg} / \mathrm{m}^{2}\right)$, vidējais \pm SD & $29,7 \pm 4,6$ \\
\hline Adipozitāte $\left(\mathrm{K} M \mathrm{MI}>30 \mathrm{~kg} / \mathrm{m}^{2}\right), \mathrm{n}(\%)$ & $40(42,6)$ \\
\hline Vidukḷa apkārtmērs $(\mathrm{cm})$, vidējais \pm SD & $103,5 \pm 11,0$ \\
\hline Aktīvs smēksētājs, n (\%) & $11(11,7)$ \\
\hline $\mathrm{CD}, \mathrm{n}(\%)$ & $28(29,8)$ \\
\hline $\mathrm{AH}, \mathrm{n}(\%)$ & $84(89,4)$ \\
\hline I pakāpe & $14(18,2)$ \\
\hline II pakāpe & $58(75,3)$ \\
\hline III pakāpe & $5(6,5)$ \\
\hline HSM, n (\%) & $59(64,1)$ \\
\hline NYHA I & $18(30,5)$ \\
\hline NYHA II & $38(64,4)$ \\
\hline NYHA III & $3(5,1)$ \\
\hline CABG anamnēzē, n (\%) & $2(2,1)$ \\
\hline PCI anamnēzēen n (\%) & $30(31,9)$ \\
\hline PCI indikācija, n (\%) & \\
\hline Stabila KSS & $75(79,8)$ \\
\hline Nestabila stenokardija & $9(9,6)$ \\
\hline STEMI & $8(8,5)$ \\
\hline NSTEMI & $2(2,1)$ \\
\hline Prehospitālā medikamentozā terapija & \\
\hline Aspirīns & $71(75,5)$ \\
\hline Aspirīna deva: $50 \mathrm{mg} /$ dienā & $1(1,5)$ \\
\hline 75 mg/dienā & $15(22,4)$ \\
\hline $100 \mathrm{mg} /$ dienā & $45(67,1)$ \\
\hline $150 \mathrm{mg} /$ dienā & $6(9,0)$ \\
\hline Klopidogrels & $6(6,4)$ \\
\hline PSI & $12(13,3)$ \\
\hline PSI tips: & \\
\hline Pantoprazols & $6(50,0)$ \\
\hline Omeprazols & $6(50,0)$ \\
\hline Statīni & $68(75,6)$ \\
\hline BB & $65(72,2)$ \\
\hline AKEI un A2RB & $64(71,1)$ \\
\hline KKB & $35(38,9)$ \\
\hline Nitrāti & $17(18,9)$ \\
\hline Antiaritmiskie līdzekḷi & $1(1,1)$ \\
\hline Benzodiazepīni & $3(3,4)$ \\
\hline Omega-3 & $16(18,0)$ \\
\hline
\end{tabular}




\begin{tabular}{ll}
\hline Parametrs & \\
\hline Laboratoriskie raksturlielumi, vidējais \pm SD & \\
Leikocītu skaits, $10^{9} / 1$ & $7,7 \pm 2,2$ \\
Hemoglobīns, g/l & $1,4 \pm 0,2$ \\
Trombocītu skaits, $10^{3} / 1$ & $224,7 \pm 52,4$ \\
Fibrinogēns, g/l & $3,4 \pm 1,3$ \\
Kreatinīns, $\mu \mathrm{mol} / \mathrm{l}$ & $83,8 \pm 23,7$ \\
Nieru filtrācijas ātrums, ml/min & $63,2 \pm 23,9$ \\
KH, mmol/1 & $4,6 \pm 1,4$ \\
ABLH, mmol/1 & $1,2 \pm 0,4$ \\
ZBLH, mmol/1 & $2,7 \pm 1,1$ \\
TG, mmol/1 & $1,4 \pm 0,9$
\end{tabular}

ĶMI - ķermeņa masas indekss, CABG - koronāro artēriju šuntēšana, STEMI - miokarda infarkts ar ST segmenta elevācijām, NSTEMI - miokarda infarkts bez ST segmenta elevācijām, CD cukura diabēts, MI - miokarda infarkts, PCI - perkutāna koronāra intervence, HSM - hroniska sirds mazspēja, AH - arteriāla hipertensija, PSI - protonu sūkṇa inhibitori, BB - beta blokatori, KKB - kalcija kanālu blokatori, AKEI - angiotenzīna konvertējošā enzīma inhibitori, A2RB - angiotenzīna II receptoru blokatori, KH - kopējais holesterīns, ABLH - augsta blīvuma lipoproteīnu holesterīns, ZBLH - zema blīvuma lipoproteīnu holesterīns, TG - triglicerīdi, SD - standartdeviācija.

\subsection{PRI variabilitāte pēc pirmās klopidogrela PD}

Pacienti pirms PCI saņēma klopidogrela PD, attiecīgi 89,4\% pacientu saņēma $300 \mathrm{mg}$, savukārt 10,6\% - 600 mg (skat. 3.1. attēlu). Vidējais PRI1 pēc pirmās

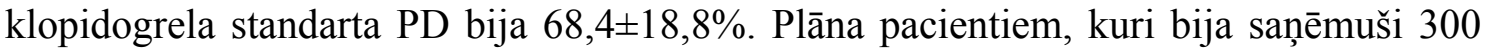
mg klopidogrela PD, PRI1 nebija statistiski ticami zemāks, salīdzinot ar akūtiem pacientiem, kuri saņēma lielāku $(600 \mathrm{mg})$ klopidogrela PD atbilstoši vadlīnijām $(67,7 \pm 19,6$ vs $74,0 \pm 8,0 ; \quad \mathrm{p}=0,321)$. Tika novērota liela PRI1 interindividuālā variabilitāte pētījuma pacientu vidū pēc klopidogrela standarta PD saņemšanas, attiecīgi no $8 \%$ līdz 94\%. Lielākai daļai no pacientiem pēc pirmās PD PRI bija virs $60 \%(\mathrm{n}=68$; 72,3\%) (skat. 3.2. attēlu). Visiem pacientiem ar pirmo PD $600 \mathrm{mg}$ PRI1 $\geq 60 \%$. 
- $300 \mathrm{mg} \quad 600 \mathrm{mg}$

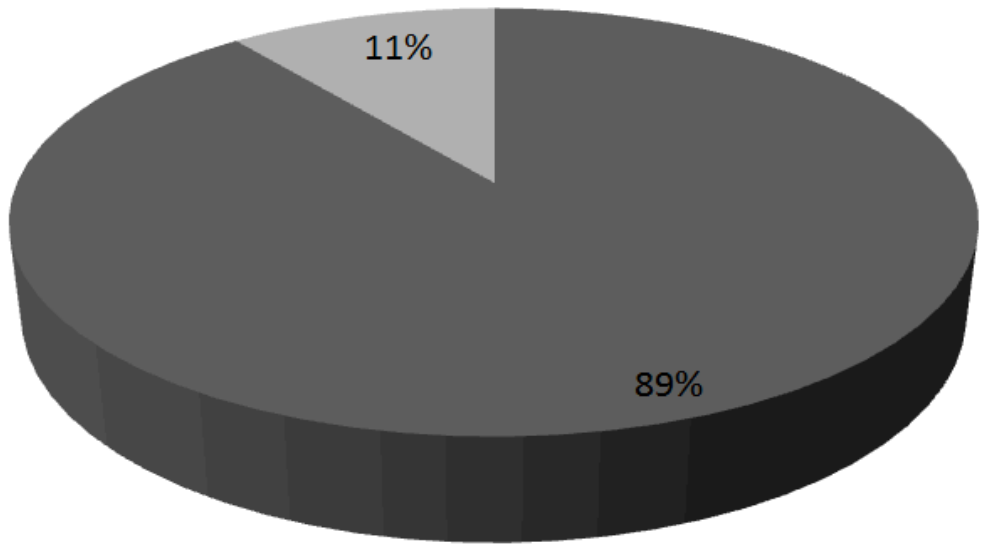

3.1.att. Klopidogrela standarta piesātinošās devas analīze

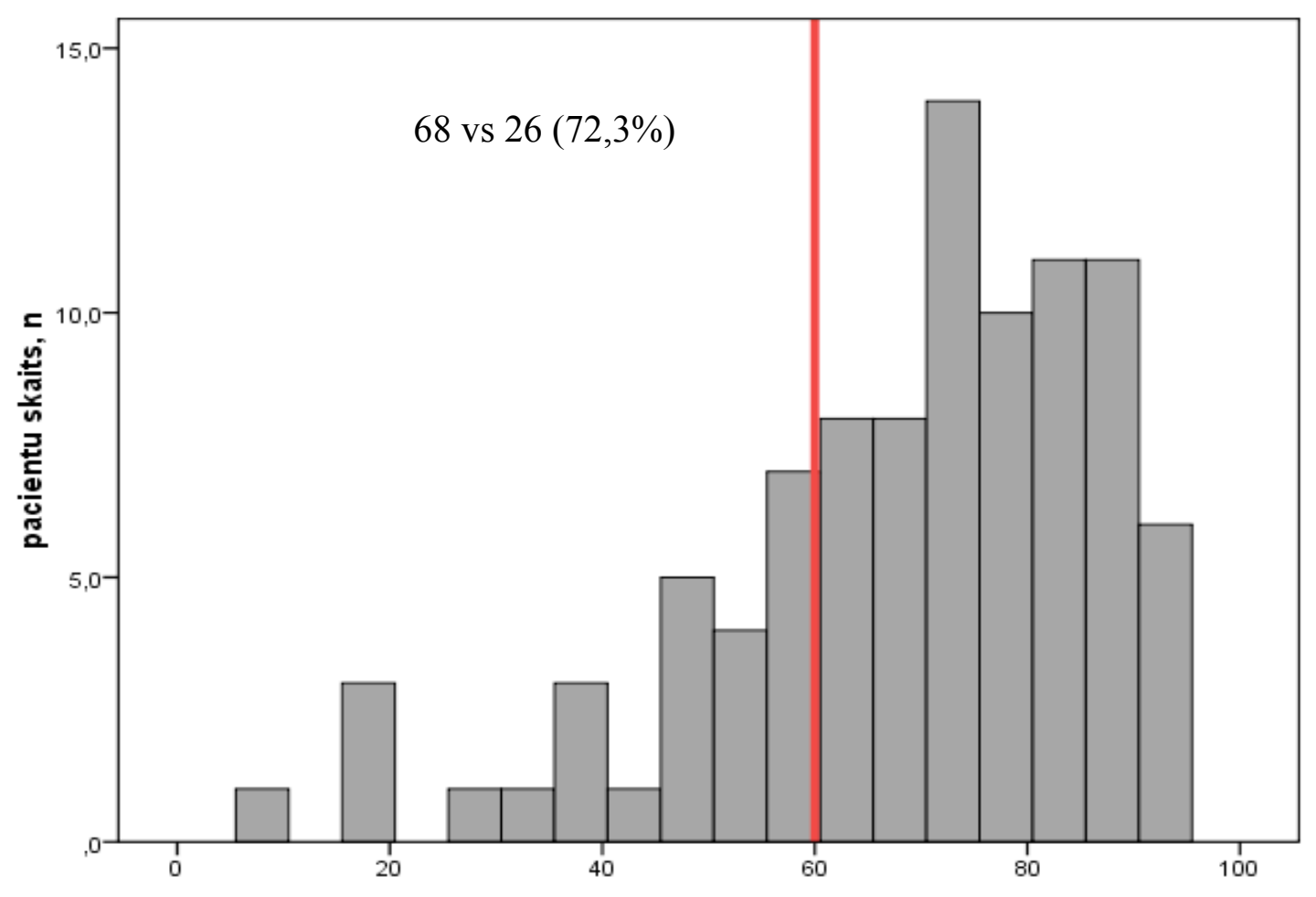

PRI 1, \%

3.2.att. Trombocītu reaktivitātes indeksa variabilitāte pacientiem pēc klopidogrela standarta PD saṇemšanas

PRI1 - pirmā VASP PRI analīze, PRI - trombocītu reaktivitātes indekss. 


\subsection{Klopidogrela papildu PD efekts pacientiem ar PRI1 $\geq 60 \%$}

Pacienti saṇēma papildu PD, lai iegūtu PRI $<60 \%$. Papildu PD efektivitāte redzama 3.3. attēlā. Mērķa PRI tika sasniegts pēc vienas, divām vai trīs papildu PD, attiecīgi $44(46,8 \%), 13(13,8 \%)$ un $9(9,6 \%)$ pacientiem. Atbilstoši pētījuma protokolam biežāk pacienti saṇēma vienu klopidogrela papildu PD $(n=42)$, retāk divas $(n=12)$ vai trīs $(n=10)$ papildu PD (skat. 3.5. attēlu). Pēc maksimālā papildu PD skaita saņemšanas tikai 2 pacientiem neizdevās iegūt PRI $<60 \%$, kuriem tika nozīmēta cita antiagreganta (tikagrelora) terapija, kura FUP analīzē pēc 40 dienām uzrādīja

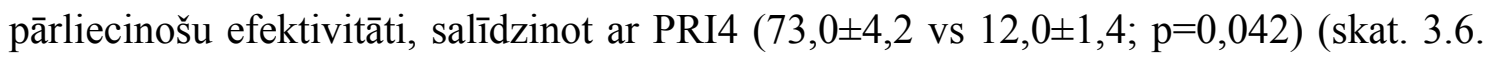
attēlu).

Pilnas novērošanas analīzes laikā pacientiem ar pirmo PRI $\geq 60 \%$ tika pārbaudīta dažādu UD efektivitāte, attiecīgi pēc 10 dienām - UD 150 mg / dienā un pēc 40 dienām - UD $75 \mathrm{mg} /$ dienā, savukārt pacientiem ar pirmo PRI $<60 \%$ - kontrole tikai pēc 40 dienām (UD 75 mg / dienā). Rezultāti par PRI variabilitāti atkarībā no dažādām UD apkopoti 3.4. attēlā. Tikai 8 (12,1\%) pacientiem ar PRI1 $\geq 60 \%$ paaugstinātas UD (150 mg / dienā) lietošanas laikā novēroja neapmierinošu atbildes reakciju uz klopidogrela terapiju (PRI FU10 $\geq 60 \%$ ), kas bija statistiski ticami retāk, salīdzinot ar standarta UD atbilstoši vadlīnijām (75 mg / dienā), kad PRI FU40 $\geq 60 \%$ konstatēja 33 (50,0\%) pacientiem $(\mathrm{p}<0,001)$. Pacientiem ar PRI1 $<60 \%$ statistiski ticami retāk $(n=2 ; 7,7 \%)$ novēroja neapmierinošu klopidogrela atbildes reakciju standarta UD lietošanas laikā pēc 40 dienām nekā pacientiem ar PRI1 $\geq 60 \%(\mathrm{p}<0,001)$. 


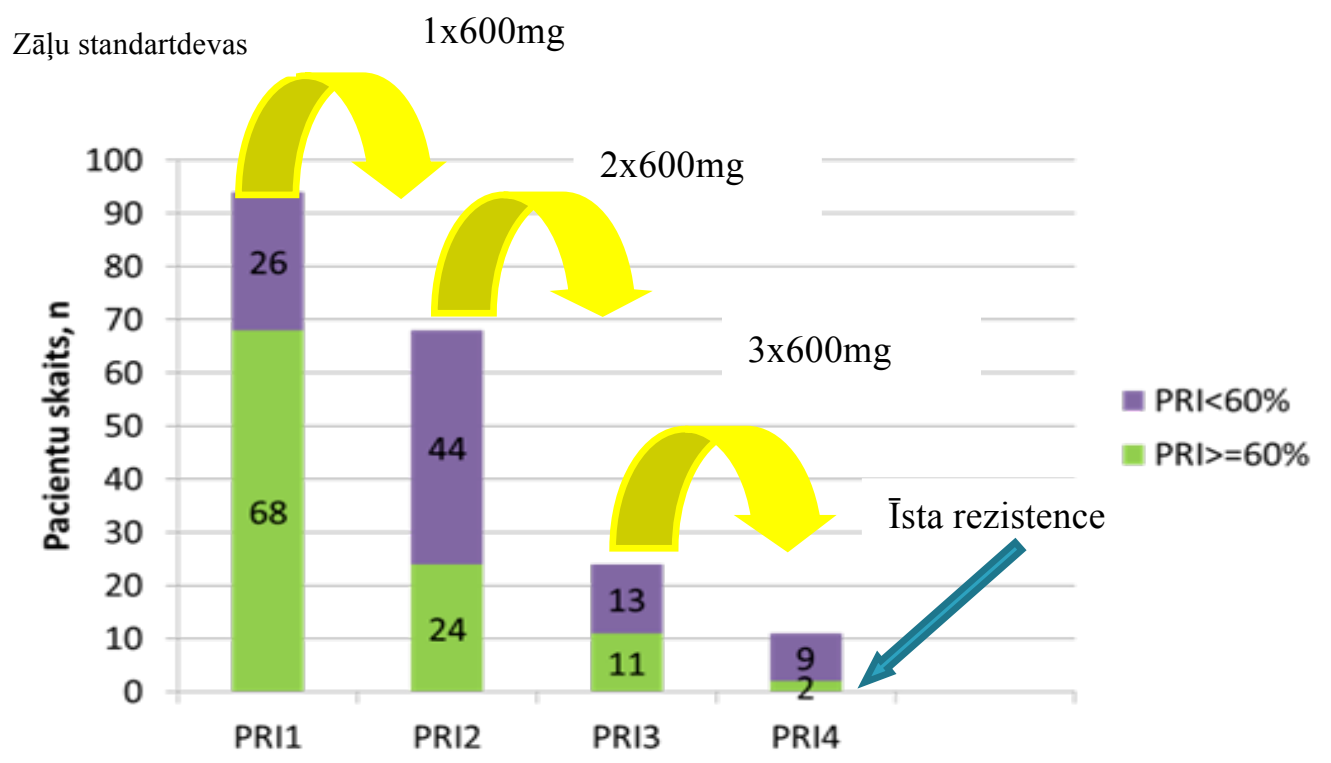

3.3.att. PRI rezultāti pacientiem, kam pielietotas papildu PD (600mg) (n=94)

PRI1 - pirmā VASP PRI analīze, PRI2, PRI3, PRI4 - attiecīgi PRI pēc pirmās, otrās un trešās klopidogrela papildu PD saņemšanas.

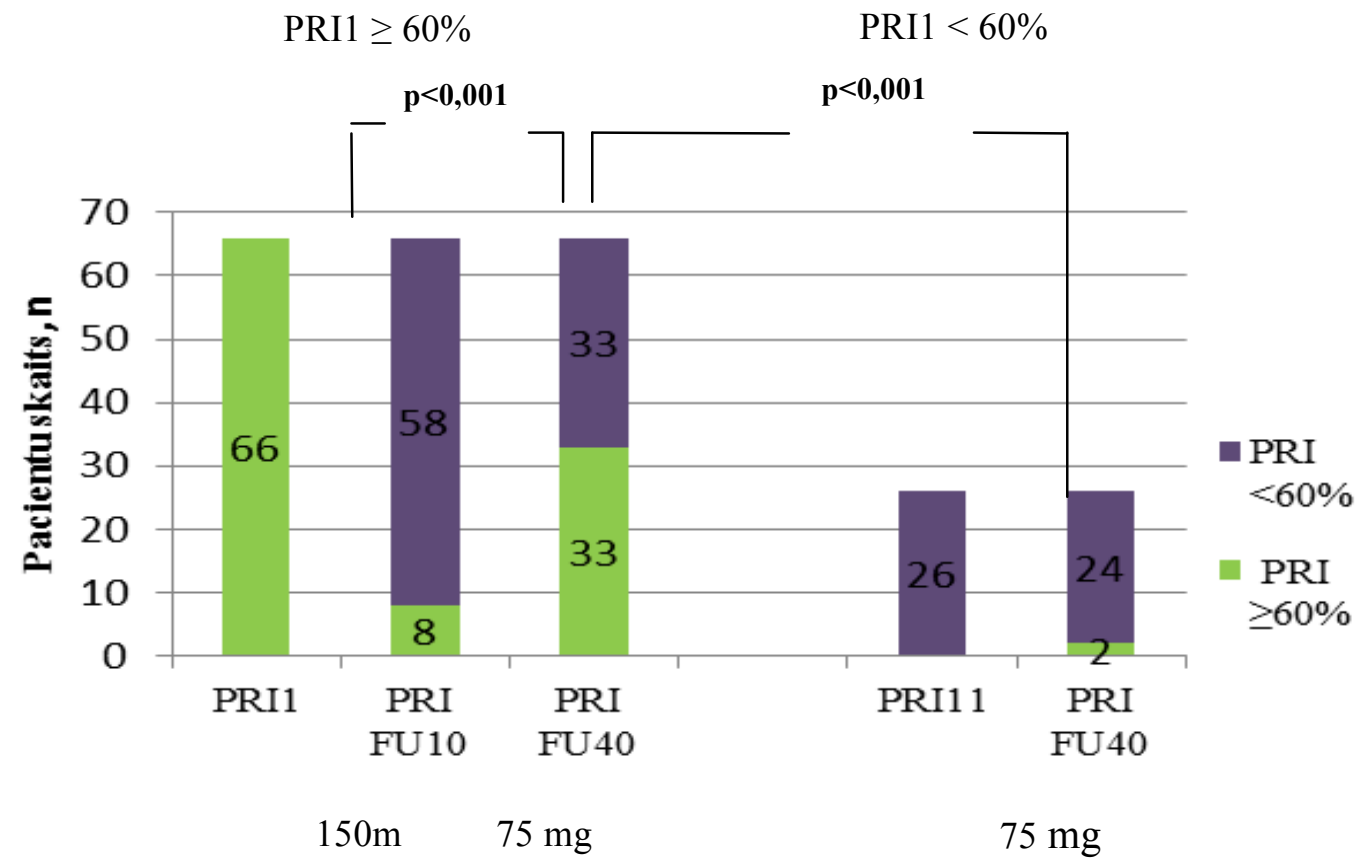

\section{4.att. VASP PRI rezultāti pacientiem ar pirmo PRI $\geq 60 \%$ un PRI $<60 \%$ un pilnu novērojumu $(\mathrm{n}=66 \text { vs } 26)^{*}$}

*Izṇemot pacientus ar tikagrelora terapiju. Aprēķinos izmantots Chi-square tests. PRI1 - pirmā VASP PRI analīze, PRI FU10 - 10. dienas apsekošanas vizītes PRI analīze, PRI FU40 - 40. dienas apsekošanas vizìtes PRI analīze. 


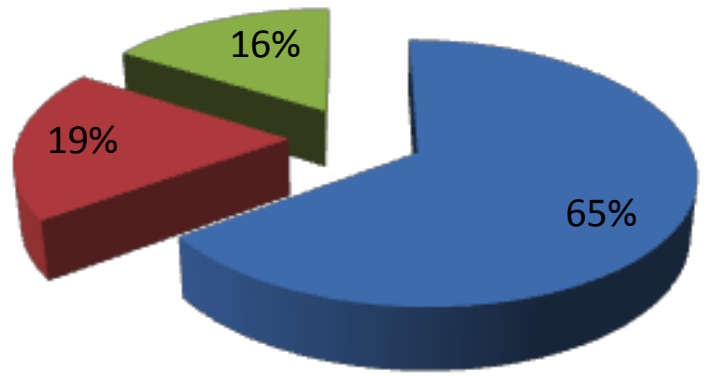

3.5. att. Klopidogrela papildu PD raksturojums pacientiem ar PRI1 $\geq 60 \%$

Tikagrelors



\section{6.att. Pacienti ar klopidogrela rezistenci}

PRI1 - pirmā VASP PRI analīze, PRI2, PRI3, PRI4 - attiecīgi PRI pēc pirmās, otrās un trešās klopidogrela papildu PD saņemšanas. PRI FU40 - 40. dienas apsekošanas vizītes PRI analīze. 


\subsection{Rezistento pacientu raksturojums}

\section{Pacients $A$}

Sieviete, 69 g.v. Stacionēta plāna kārtā ar diagnozi stabila stenokardija, saņēmusi klopidogrelu 300mg PD. ĶMI 40,0 kg/m2, nesmēķēe. Arteriāla hipertensija 40 gadus, HSM II FK (NYHA). MI, CD, CI, HNS anamnēzē noliedz, PCI un CABG iepriekš nav veikta.

Lietotie medikamenti: aspirīns, statīni, BB, AKEI/A2RB, KKB; klopidogrelu iepriekš nav lietojusi. Stacionārā KH 7,2 mmol/1, ABLH 1,17 mmol/1, ZBLH 4,8 mmol/1, TG 2,6 mmol/1. Genotips CYP2C19*2 - AG, CYP2C19*17 - CT, CYP2C9*2 - CC, CYP2C $9 * 3-$ AA.

VASP rezultāti: PRI $=84 \%, 80 \%, 81 \%, 70 \%$; uzsākts tikagrelors (FU40 VASP PRI $=13 \%)$.

\section{Pacients $B$}

Sieviete, 48 g.v. Stacionēta plāna kārtā ar diagnozi stabila stenokardija, saņēmusi klopidogrelu 300 mg PD. ĶMI 33,0 kg/m², bijusi smēķētāja (35 pac.g.), pārtraukusi mazāk kā pirms gada. Primāra AH 2. pakāpe 10 gadus, HSM I FK (NYHA), neinsulinējams CD 10 gadus. MI, CI, HNS anamnēzē noliedz, PCI un CABG iepriekš nav veikta.

Lietotie medikamenti: aspirīns, statīni, BB, AKEI/A2RB; klopidogrelu iepriekš nav lietojusi. Stacionārā KH 3,7 mmol/1, ABLH 1,01 mmol/1, ZBLH 2,0 mmol/1, TG 1,4 mmol/1, glikoze 7,9 mmol/l. Genotips CYP2C19*2 - AG, CYP2C19*17 - CC, CYP2C $9 * 2-\mathrm{CC}, \mathrm{CYP} 2 \mathrm{C} 9 * 3-\mathrm{AA}$.

VASP rezultāti: PRI $=92 \%, 83 \%, 81 \%, 76 \%$; uzsākts tikagrelors (FU40 VASP PRI $=11 \%)$.

\subsection{Pacientu kopas ǵenētiskais raksturojums}

Ģenētisko analīžu rezultāti un alẹlu biežums pacientu kopā parādīts 3.2. tabulā. CYP2C19*5 polimorfismam atkārtoti nebija izdevies noteikt genotipu trīs pacientiem. Tā kā šajā polimorfismā nenovēroja genotipu variācijas, turpmāki š̄ genotipa noteikšanas mēǵinājumi šiem pacientiem netika veikti. Analizētie polimorfismi bija 
Hārdija-Veinberga līdzsvarā. Ģenētiskās analīzes tika veiktas 93 pacientiem, jo viens pacients no tām attiecās pētîjuma laikā.

3.2. tabula

Ģenētiskās variācijas pacientu kopā

\begin{tabular}{|c|c|c|c|c|c|}
\hline Polimorfisms & Genotips & $\begin{array}{l}\text { Pacientu } \\
\text { skaits, } \\
\text { n (\%) }\end{array}$ & $\mathbf{p}$ & Alēle & $\begin{array}{l}\text { Alēles } \\
\text { prevalence }\end{array}$ \\
\hline \multicolumn{6}{|l|}{ CYP2C19 } \\
\hline CYP $2 C 19 * 2$ & $\mathrm{GG}(w t / w t)$ & $71(76,3)$ & 0,686 & G & $0,876(163)$ \\
\hline (G681A) & $A G(w t / * 2)$ & $21(22,6)$ & & A & $0,124(23)$ \\
\hline$r s 4244285) \neq$ & $\mathrm{AA}(* 2 / * 2)$ & $1(1,1)$ & & & \\
\hline$C Y P 2 C 19 * 3$ & GG (wt/wt) & $92(98,9)$ & 0,958 & $\mathrm{G}$ & 0,995 (185) \\
\hline $\begin{array}{l}(G 636 A / \\
r s 4986893)\end{array}$ & $A G(w t / * 3)$ & $1(1,1)$ & & A & $0,005(1)$ \\
\hline СYР $2 C 19 * 5$ & $\mathrm{CC}(\mathrm{wt} / \mathrm{wt})$ & $90(100,0)$ & NA & $\mathrm{C}$ & $1,000(90)$ \\
\hline $\begin{array}{l}(C 1297 T / \\
r s 56337013)\end{array}$ & $\mathrm{CT}(\mathrm{wt} / * 5)$ & & & & \\
\hline СYР $2 C 19 * 17$ & $\mathrm{CC}(\mathrm{wt} / \mathrm{wt})$ & $36(38,7)$ & 0,523 & $\mathrm{C}$ & 0,634 (118) \\
\hline (C806T) & $\mathrm{CT}\left(\mathrm{wt} /{ }^{*} 17\right)$ & $46(49,5)$ & & $\mathrm{T}$ & $0,366(68)$ \\
\hline rs 12248560) & $\mathrm{TT}(* 17 / * 17)$ & $11(11,8)$ & & & \\
\hline \multicolumn{6}{|l|}{ CYP2C9 } \\
\hline CYP $2 C 9 * 2$ & $\mathrm{CC}(\mathrm{wt} / \mathrm{wt})$ & $86(92,5)$ & 0,706 & $\mathrm{C}$ & 0,962 (179) \\
\hline $\begin{array}{l}(C 430 T / \\
r s 1799853)\end{array}$ & $\mathrm{CT}(\mathrm{wt} / * 2)$ & $7(7,5)$ & & $\mathrm{T}$ & $0,038(7)$ \\
\hline$C Y P 2 C 9 * 3$ & $\mathrm{AA}(w t / w t)$ & $79(84,9)$ & 0,433 & A & 0,925 (172) \\
\hline $\begin{array}{l}(\mathrm{A} 1075 \mathrm{Cl} \\
r s 1057910)\end{array}$ & $\mathrm{CA}(\mathrm{wt} / * 3)$ & $14(15,1)$ & & $\mathrm{C}$ & $0,075(14)$ \\
\hline \multicolumn{6}{|l|}{$A B C B 1$} \\
\hline$A B C B 1$ & $\mathrm{CC}$ & $17(18,2)$ & 0,410 & $\mathrm{C}$ & $0,452(84)$ \\
\hline (C3435T) & CT & $50(53,8)$ & & $\mathrm{T}$ & $0,548(102)$ \\
\hline$r s 1045642)$ & TT & $26(28,0)$ & & & \\
\hline
\end{tabular}

†Iekavās kursīvā norādītas nukleotīdu izmaiņas un kārtas numuri Nacionālajā Biotehnoloǵiju Informācijas centra SNP (single-nucleotide polymorphism) datubāzē (bdSNP). NA - nav piemērojams (angl. non-applicable).Ar wt apzīmēta biežāk sastopamā (wild-type) neizmainītas funkcijas citohroma alēle.

\subsection{PRI variabilitāte atkarībā no genotipa}

\subsubsection{PRI1 rezultāti atkarībā no $C Y P 2 C 19, C Y P 2 C 9$ un $A B C B 1$ genotipiem}

Vidējie PRI1 rezultāti katrā polimorfismu grupā apkopoti 3.3. tabulā. PRI1 bija augstāks gan $C Y P 2 C 19 * 2$ alēles homozigotam $(* 2 / * 2)$, gan heterozigotiem $(\mathrm{wt} / * 2)$, salīdzinot ar neizmainītas funkcijas alēles nēsātājiem (wt/wt), attiecīgi 89,0 0 , $77,7 \pm 13,2$ un 65,3 $\pm 19,5$ (p=0,016). Vismaz vienas CYP2C19*2 alēles nēsātāji (wt/*2 un 
*2/*2) uzrādīja statistiski ticami augstāku PRI1, salīdzinot ar normālu genotipu (wt/wt), attiecīgi 78,2 $\pm 13,1$ un $65,3 \pm 19,5 ; \mathrm{p}=0,005$ (skat. 3.7. attēlu).

CYP2C19*17 paaugstinātas funkcijas alēles nēsātājiem (wt/*17 un *17/*17) novēroja tendenci uz samazinātu PRI, salīdzinot ar neizmainītas funkcijas alēles

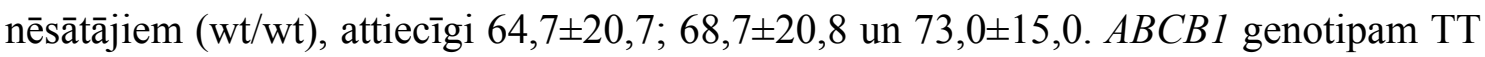
homozigoti uzrādīja augstāku PRI, salīdzinot ar šīs alēles heterozigotiem, attiecīgi $72,8 \pm 16,9$ un $66,5 \pm 18,7$. Pārējiem polimorfismiem nenovēro būtisku ietekmi uz PRI.

Pirmās klopidogrela piesātinošās devas efektivitāte genotipu grupās attēlota 3.4. tabulā. Pacientu prevalence ar vismaz vienu CYP2C19*2 samazinātas funkcijas alēli bija statistiski ticami augstāka grupā ar PRI1 $\geq 60 \%$, salīdzinot ar neizmainītas funkcijas alēles nēsātājiem, attiecīgi 86,4\% (19/22) un 67,6\% (48/71); p=0,087 (skat. 3.8. attēlu).

Vidējās PRI1 vērtības polimorfismu genotipu grupās $(\mathbf{n}=93)$

\begin{tabular}{lll}
\hline Polimorfisms & PRI1, \% (SD) & p \\
\hline CYP2C19*2 & $65,3(19,5)$ & $\mathbf{0 , 0 1 6}$ \\
$\mathrm{wt} / \mathrm{wt}$ & $77,7(13,2)$ & \\
$\mathrm{wt} / * 2$ & $89,0(-)$ & \\
$* 2 / * 2$ & & 0,472 \\
CYP2C19*3 & $68,2(19,0)$ & \\
$\mathrm{wt} / \mathrm{wt}$ & $82,0(-)$ & \\
$\mathrm{wt} / * 3$ & & \\
$C Y P 2 C 19 * 17$ & $73,0(15,0)$ & \\
$\mathrm{wt} / \mathrm{wt}$ & $64,7(20,7)$ & \\
$\mathrm{wt} / * 17$ & $68,7(20,8)$ & \\
$* 17 / * 17$ & & \\
$C Y P 2 C 9 * 2$ & $68,6(18,9)$ & \\
$\mathrm{wt} / \mathrm{wt}$ & $65,6(20,6)$ & \\
$\mathrm{wt} / * 2$ & & \\
$C Y P 2 C 9 * 3$ & $69,1(17,7)$ & \\
$\mathrm{wt} / \mathrm{wt}$ & $64,3(25,2)$ & \\
$\mathrm{wt} / * 3$ & & \\
$A B C B 1$ & $67,0(22,5)$ & \\
$\mathrm{CC}$ & $66,5(18,7)$ & \\
$\mathrm{CT}$ & $72,8(16,9)$ & \\
$\mathrm{TT}$ &
\end{tabular}

Aprēķinos izmantots neatkarīgo izlašu t-tests (2 grupām) un one-way ANOVA variācijas analīze (3 grupām), attēloti vidējie rezultāti. PRI1 - pirmā VASP PRI analīze pēc pirmās klopidogrela standarta PD saṇemšanas. 
Pacientu procentuālais sadalījums pēc PRI1 atkarībā no CYP2C19*17 genotipa attēlots 3.9. attēlā. Pacienti ar CYP2C19*17 neizmainītas funkcijas alēlēm (wt/wt) biežāk bija grupā ar PRI $\geq 60 \%$ nekā pacientu grupā ar PRI $<60 \%$, attiecīgi 80,6\% un $19,4 \%(\mathrm{p}=0,146)$.

Pirmās klopidogrela piesātinošās devas efekts genotipu grupās $(n=93)$

\begin{tabular}{|c|c|c|}
\hline Polimorfisms & $\begin{array}{l}\text { PRI1 } \geq 60 \%, \\
\text { n (\%) }\end{array}$ & $\mathbf{p}$ \\
\hline $\begin{array}{l}C Y P 2 C 19 * 2 \\
\mathrm{wt} / \mathrm{wt} \\
\mathrm{wt} / * 2 \\
* 2 / * 2\end{array}$ & $\begin{array}{l}48 / 71(67,6) \\
18 / 21(85,7) \\
1 / 1(100,0)\end{array}$ & 0,220 \\
\hline $\begin{array}{l}\text { CYP2C19*3 } \\
\mathrm{wt} / \mathrm{wt} \\
\mathrm{wt} / * 3\end{array}$ & $\begin{array}{l}66 / 92(71,7) \\
1 / 1(100,0)\end{array}$ & 1,000 \\
\hline $\begin{array}{l}\text { СУР 2C19*17 } \\
\mathrm{wt} / \mathrm{wt} \\
\mathrm{wt} / * 17 \\
* 17 / * 17\end{array}$ & $\begin{array}{l}29 / 36(80,6) \\
30 / 46(65,2) \\
8 / 11(72,7)\end{array}$ & 0,307 \\
\hline $\begin{array}{l}C Y P 2 C 9 * 2 \\
\text { wt/wt } \\
w t / 22\end{array}$ & $\begin{array}{l}63 / 86(73,4) \\
4 / 7(57,1)\end{array}$ & 0,361 \\
\hline $\begin{array}{l}C Y P 2 C 9 * 3 \\
w t / w t \\
w t / * 3\end{array}$ & $\begin{array}{l}58 / 79(73,4) \\
9 / 14(64,3)\end{array}$ & 0,488 \\
\hline $\begin{array}{l}A B C B 1 \\
\text { CC } \\
\text { CT } \\
\text { TT }\end{array}$ & $\begin{array}{l}11 / 17(64,7) \\
36 / 50(72,0) \\
20 / 26(76,9)\end{array}$ & 0,683 \\
\hline
\end{tabular}

Aprēķinos izmantots Chi-square tests. PRI1 - pirmā VASP PRI analīze pēc pirmās klopidogrela standarta PD saņemšanas. Iekavās norādīti procenti no kopējā pacientu skaita ar šādu genotipu. 


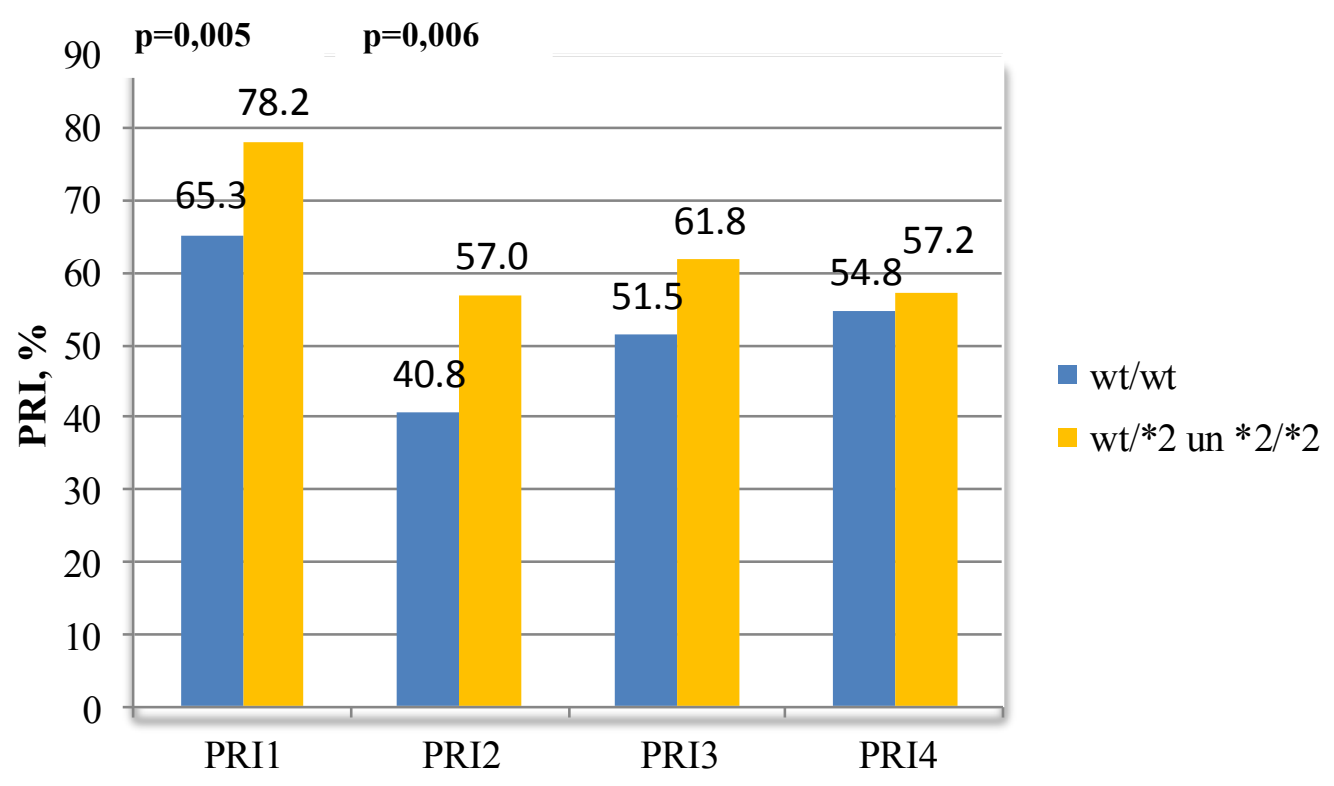

3.7. att. PRI variabilitāte atkarībā no CYP2C19*2 genotipa pēc klopidogrela papildu PD (n=93)

Aprēḳinos izmantots neatkarīgo izlašu t-tests, attēloti vidējie rezultāti. PRI1 - pirmā VASP PRI analīze, PRI2, PRI3, PRI4 - attiecīgi PRI pēc pirmās, otrās un trešās klopidogrela papildu PD saņemšanas.



\section{8. att. Pirmās klopidogrela PD efektivitātes atšksirīibas no CYP2C19*2 genotipa}

Aprēķinos izmantots Chi-square tests. PRI1 - pirmā VASP PRI analīze pēc pirmās klopidogrela standarta PD saņemšanas. Attēloti procenti no kopējā pacientu skaita ar šādu genotipu. 


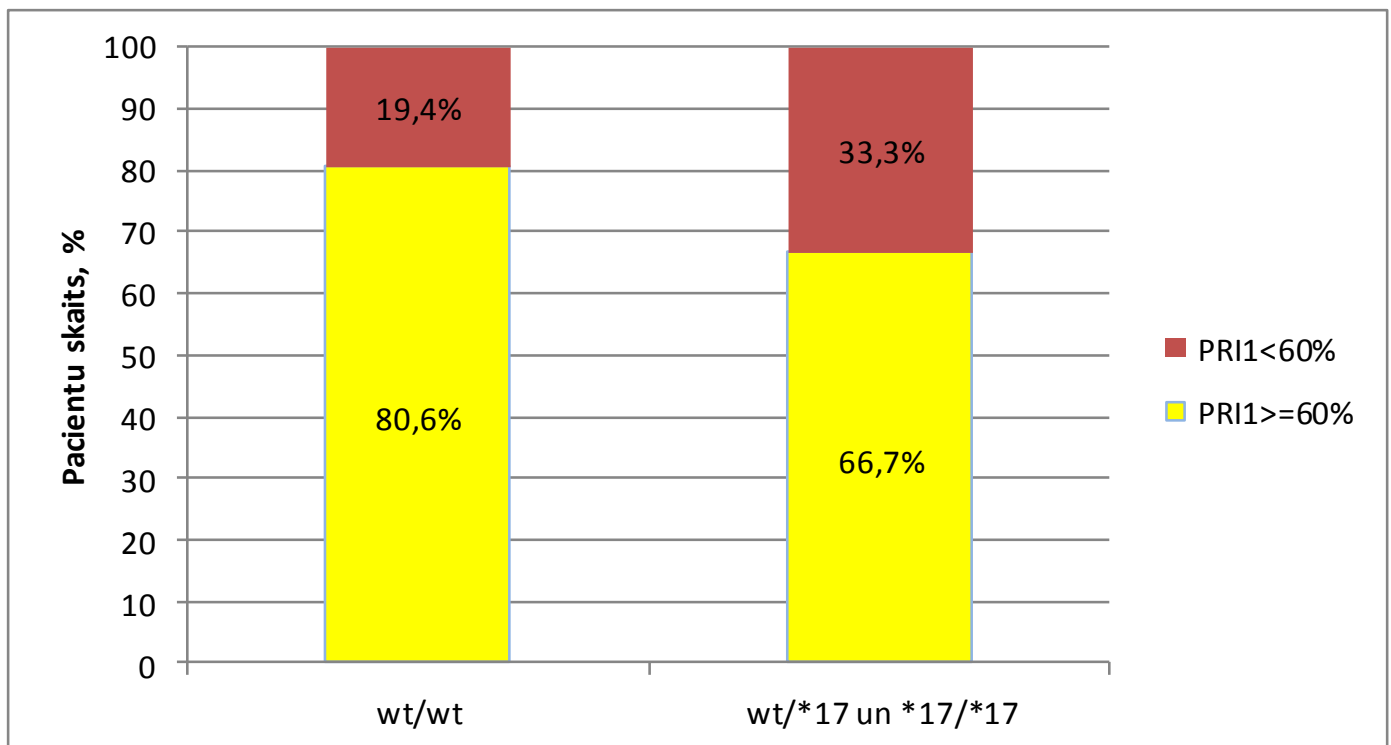

\section{9. att. Pirmās klopidogrela PD efektivitātes atšksirības no $C Y P 2 C 19 * 17$ genotipa}

Aprēķinos izmantots Chi-square tests. PRI1 - pirmā VASP PRI analīze pēc pirmās klopidogrela standarta PD saņemšanas. Attēloti procenti no kopējā pacientu skaita ar šādu genotipu.

\subsubsection{PRI2 rezultāti atkarībā no $C Y P 2 C 19, C Y P 2 C$ un $A B C B 1$ genotipiem}

Pacientu rezultāti, kuriem pēc klopidogrela standarta PD PRI $\geq 60 \%(n=67)$ un kuri san̦ēmuši pirmo klopidogrela papildu PD, apkopoti 3.5. un 3.6. tabulā.

CYP2C19*2 vismaz vienas samazinātas funkcijas alēles nēsātājiem vidējais PRI2 bija statistiski ticami augstāks, salīdzinot ar neizmainītas funkcijas alēles nēsātājiem, attiecīgi 57,0 $\pm 19,1$ un 40,8 $\pm 21,5$; p=0,006. Pēc pirmās klopidogrela papildu PD novēroja statistiski ticami mazāku PRI samazinājumu CYP2C19*2 vismaz vienas samazinātas funkcijas alēles nēsātājiem, salīdzinot ar normāla genotipa pacientiem $(25,5 \pm 15,6$ un $35,5 \pm 16,8 ; p=0,025)$. Pēc pirmās klopidogrela papildu PD pacientu grupā ar novērotu hiporesponsivitāti (PRI2 $\geq 60 \%$ ) statistiski ticami biežāk bija pacienti ar CYP2C19*2 alēli, salīdzinot ar pacientiem bez šī polimorfisma, attiecīgi *2/*2 - 100\%, $\mathrm{wt} / * 2-55,6 \%$ un wt/wt $-27,1 \% ; \mathrm{p}=0,040$ (skat. 3.6.tabulu). Šāda tendence pacientiem ar CYP2C19*2 genotipu saglabājās arī pēc otrās un trešās papildu PD saņemšanas (skat. 3.7. līdz 3.10. tabulu).

CYP2C19*17 vismaz vienas pastiprinātas funkcijas alēles nēsātājiem novēroja


un $47,4 \pm 20,9 ; p=0,517$. Šìs alēles ietekme vērojama arī pēc pirmās klopidogrela papildu 
PD, kad PRI samazinājums bija lielāks pacientiem ar CYP2C19*17, salīdzinot ar neizmainītas funkcijas alēles nēsātājiem $(33,3 \pm 17,8$ un $31,7 \pm 16,2 ; p=0,705)$.

Citu apskatīto genotipu grupās šādas atšķirības netika novērotas.

3.5. tabula

Vidējās PRI2 un vidējās $\Delta$ PRI1-2 vērtības katrā genotipa grupā $(n=67) *$

\begin{tabular}{|c|c|c|c|c|c|}
\hline Polimorfisms & $\mathbf{n}$ & $\begin{array}{l}\text { Vid. PRI2, \% } \\
\text { (SD) }\end{array}$ & $\mathbf{p}$ & $\begin{array}{l}\text { Vid. } \triangle \text { PRI-PRI2, } \\
\% \text { p (SD) }\end{array}$ & $\mathbf{p}$ \\
\hline \multicolumn{6}{|l|}{ CYP2C19*2 } \\
\hline $\mathrm{wt} / \mathrm{wt}$ & 48 & $40,8(21,5)$ & 0,006 & $35,5(16,8)$ & $\mathbf{0 , 0 2 5}$ \\
\hline wt $/ * 2$ un $* 2 / * 2$ & 19 & $57,0(19,1)$ & & $25,2(15,6)$ & \\
\hline \multicolumn{6}{|l|}{ СYР 2 C19*17 } \\
\hline$w t / w t$ & 29 & $47,4(20,9)$ & 0,517 & $31,7(16,2)$ & 0,705 \\
\hline $\mathrm{wt} / * 17$ un $* 17 / * 17$ & 38 & $43,9(22,9)$ & & $33,3(17,8)$ & \\
\hline \multicolumn{6}{|l|}{ СУР $2 C 19 * 3$} \\
\hline $\mathrm{wt} / \mathrm{wt}$ & 66 & $45,1(22,0)$ & 0,398 & $32,8(17,1)$ & 0,392 \\
\hline $\mathrm{wt} / * 3$ & 1 & $64,0(-)$ & & $18,0(-)$ & \\
\hline \multicolumn{6}{|l|}{$C Y P 2 C 9 * 2$} \\
\hline $\mathrm{wt} / \mathrm{wt}$ & 63 & $45,5(21,9)$ & 0,878 & $32,3(17,1)$ & 0,659 \\
\hline $\mathrm{wt} / * 2$ & 4 & $43,8(27,3)$ & & $36,3(17,4)$ & \\
\hline \multicolumn{6}{|l|}{ CYP $2 C 9 * 3$} \\
\hline $\mathrm{wt} / \mathrm{wt}$ & 58 & $44,7(22,5)$ & 0,525 & $32,9(17,5)$ & 0,691 \\
\hline $\mathrm{wt} / * 3$ & 9 & $49,8(19,2)$ & & $30,4(14,3)$ & \\
\hline \multicolumn{6}{|l|}{$A B C B 1$} \\
\hline $\mathrm{CC}$ & 11 & $49,6(21,9)$ & 0,504 & $32,9(17,1)$ & 0,719 \\
\hline $\mathrm{CT} / \mathrm{TT}$ & 56 & $44,6(22,1)$ & & $30,8(17,3)$ & \\
\hline
\end{tabular}

Aprēķinos izmantots neatkarīgo izlašu t-tests, attēloti vidējie rezultāti (SD). PRI2 - VASP PRI otrā analīze, \%p - procentpunkti, $\Delta$ PRI1-2 - izmaiṇas PRI rādītājos pēc pirmās klopidogrela papildu PD saņemšanas. 
Pirmās klopidogrela papildu PD efekts katrā genotipa grupā $(n=67)$

\begin{tabular}{|c|c|c|}
\hline Polimorfisms & $\begin{array}{l}\text { PRI2 } \geq 60 \%, \\
\text { n }(\%)\end{array}$ & $\mathbf{p}$ \\
\hline $\begin{array}{l}C Y P 2 C 19 * 2 \\
\mathrm{wt} / \mathrm{wt} \\
\mathrm{wt} / * 2 \\
* 2 / * 2\end{array}$ & $\begin{array}{l}13 / 48(27,1) \\
10 / 18(55,6) \\
1 / 1(100,0)\end{array}$ & 0,040 \\
\hline $\begin{array}{l}\text { CYP2C19*3 } \\
\mathrm{wt} / \mathrm{wt} \\
\mathrm{wt} / * 3\end{array}$ & $\begin{array}{l}23 / 66(34,8) \\
1 / 1(100,0)\end{array}$ & 0,358 \\
\hline $\begin{array}{l}\text { CYP2C19*17 } \\
\mathrm{wt} / \mathrm{wt} \\
\mathrm{wt} / * 17 \\
* 17 / * 17\end{array}$ & $\begin{array}{l}11 / 29(37,9) \\
11 / 30(36,7) \\
2 / 8(25,0)\end{array}$ & 0,789 \\
\hline $\begin{array}{l}C Y P 2 C 9 * 2 \\
\text { wt/wt } \\
\text { wt } / * 2\end{array}$ & $\begin{array}{l}22 / 63(34,9) \\
2 / 4(50,0)\end{array}$ & 0,614 \\
\hline $\begin{array}{l}C Y P 2 C 9 * 3 \\
\text { wt/wt } \\
\text { wt/*3 }\end{array}$ & $\begin{array}{l}21 / 58(36,2) \\
3 / 9(33,3)\end{array}$ & 1,000 \\
\hline $\begin{array}{l}A B C B 1 \\
\text { CC } \\
\text { CT } \\
\text { TT }\end{array}$ & $\begin{array}{l}5 / 11(45,5) \\
11 / 36(30,6) \\
8 / 20(40,0)\end{array}$ & 0,597 \\
\hline
\end{tabular}

Aprēķinos izmantots Chi-square tests. PRI2 - VASP PRI analīze pēc pirmās klopidogrela papildu PD saņemšanas. Iekavās norādīti procenti no kopējā pacientu skaita ar šādu genotipu.

\subsubsection{PRI3 rezultāti atkarībā no $C Y P 2 C 19, C Y P 2 C 9$ un $A B C B 1$ genotipiem}

Pacientu rezultāti, kuriem pēc klopidogrela standarta PD un pirmās papildu PD PRI $\geq 60 \%(n=24)$ un kuri saņēmuši otro klopidogrela papildu PD, apkopoti 3.7. un 3.8. tabulā. CYP2C19*2 alēles nēsātājiem PRI atšķirības saglabājas arī pēc otrās klopidogrela papildu PD saņemšanas, attiecīgi CYP2C19*2 alēles klātbūtnē PRI bija


gan vidējais PRI š̄ genotipa grupās statistiski ticami neatšķı̄rās, tomēr PRI 
samazinājums pēc otrās klopidogrela papildu PD saglabāja statistiski ticamu atšķirību, attiecīgi 9,0 0 5,9 pacientiem ar vismaz vienu $C Y P 2 C 19 * 2$ samazinātas funkcijas alēli un $18,9 \pm 10,2$ pacientiem ar neizmainītas funkcijas $(w t / w t)$ alēlēm $(p=0,009)$. CYP2C ${ }^{*} 2$ heterozigoti biežāk bija hiporesponsivitātes grupā, salīdzinot ar pacientiem bez š̄ polimorfisma (skat. 3.8. tabulu). CYP2C19*17 alēles nēsātājiem bija vērojama tendence uz mazāku vidējo PRI3 un izteiktāku PRI samazinājumu pēc otrās klopidogrela papildu PD saņemšanas (skat. 3.7. tabulu). CYP2C19*17 polimorfismu vidū netika novērotas statistiski ticamas prevalences atšksirības hiporesponsivitātes grupā pēc otrās klopidogrela papildu PD (skat. 3.8. tabulu).

Vidējās PRI3 un vidējās $\Delta$ PRI2-3 vērtības katrā genotipa grupā (n=24)

\begin{tabular}{|c|c|c|c|c|c|}
\hline Polimorfisms & $\mathbf{n}$ & $\begin{array}{l}\text { Vid. PRI3, \% } \\
\text { (SD) }\end{array}$ & $\mathbf{p}$ & $\begin{array}{l}\text { Vid. } \triangle \text { PRI2- } \\
\text { PRI3, \%p (SD) }\end{array}$ & $\mathbf{p}$ \\
\hline $\begin{array}{l}\text { СРР 2C19*2 } \\
\mathrm{wt} / \mathrm{wt} \\
\mathrm{wt} / * 2 \text { un } * 2 / * 2\end{array}$ & $\begin{array}{l}13 \\
11\end{array}$ & $\begin{array}{l}51,5(15,2) \\
61,8(11,6)\end{array}$ & 0,078 & $\begin{array}{l}18,9(10,2) \\
9,0(5,9)\end{array}$ & 0,009 \\
\hline $\begin{array}{l}\text { СYP2C19*17 } \\
\text { wt/wt } \\
\text { wt/*17un } * 17 / * 17\end{array}$ & $\begin{array}{l}11 \\
13\end{array}$ & $\begin{array}{l}59,6(13,1) \\
53,3(15,3)\end{array}$ & 0,293 & $\begin{array}{l}11,1(7,6) \\
17,2(10,8)\end{array}$ & 0,131 \\
\hline $\begin{array}{l}\text { CYP2C19*3 } \\
\mathrm{wt} / \mathrm{wt} \\
\mathrm{wt} / * 3\end{array}$ & $\begin{array}{l}23 \\
1\end{array}$ & $\begin{array}{l}56,7(14,5) \\
44,0(-)\end{array}$ & 0,398 & $\begin{array}{l}14,1(9,9) \\
20,0(-)\end{array}$ & 0,567 \\
\hline $\begin{array}{l}C Y P 2 C 9 * 2 \\
\mathrm{wt} / \mathrm{wt} \\
\mathrm{wt} / * 2\end{array}$ & $\begin{array}{l}22 \\
2\end{array}$ & $\begin{array}{l}56,8(14,3) \\
49,5(19,1)\end{array}$ & 0,503 & $\begin{array}{l}14,1(9,9) \\
17,5(10,6)\end{array}$ & 0,729 \\
\hline $\begin{array}{l}C Y P 2 C 9 * 3 \\
w t / w t \\
w t / * 3\end{array}$ & $\begin{array}{l}21 \\
3\end{array}$ & $\begin{array}{l}55,6(14,8) \\
60,3(12,3)\end{array}$ & 0,607 & $\begin{array}{l}14,9(10,1) \\
11,0(7,8)\end{array}$ & 0,533 \\
\hline $\begin{array}{l}A B C B 1 \\
\mathrm{CC} \\
\mathrm{CT} / \mathrm{TT}\end{array}$ & $\begin{array}{l}5 \\
19\end{array}$ & $\begin{array}{l}50,2(9,8) \\
57,8(15,2)\end{array}$ & 0,304 & $\begin{array}{l}20,6(5,0) \\
12,7(10,1)\end{array}$ & 0,110 \\
\hline
\end{tabular}

Aprēķinos izmantots neatkarīgo izlašu t-tests, attēloti vidējie rezultāti (SD). PRI3 - VASP PRI trešā analīze, \%p - procentpunkti, $\Delta$ PRI2-3 - izmaiņas PRI rādītājos pēc otrās klopidogrela papildu PD saņemšanas. 
Otrās klopidogrela papildu PD efekts katrā genotipa grupā $(n=24)$

\begin{tabular}{|c|c|c|}
\hline Polimorfisms & $\begin{array}{l}\text { PRI3 } \geq 60 \%, \\
\text { n (\%) }\end{array}$ & $\mathbf{p}$ \\
\hline $\begin{array}{l}C Y P 2 C 19 * 2 \\
\mathrm{wt} / \mathrm{wt} \\
\mathrm{wt} / * 2 \\
* 2 / * 2\end{array}$ & $\begin{array}{l}5 / 13(38,5) \\
5 / 10(50,0) \\
1 / 1(100,0)\end{array}$ & 0,464 \\
\hline $\begin{array}{l}\text { CYP2C19*3 } \\
\mathrm{wt} / \mathrm{wt} \\
\mathrm{wt} / * 3\end{array}$ & $\begin{array}{l}11 / 23(47,8) \\
0 / 1(0,0)\end{array}$ & 1,000 \\
\hline $\begin{array}{l}\text { CYP2C19*17 } \\
\mathrm{wt} / \mathrm{wt} \\
\mathrm{wt} / * 17 \\
* 17 / * 17\end{array}$ & $\begin{array}{l}6 / 11(54,5) \\
4 / 11(36,4) \\
1 / 2(50,0)\end{array}$ & 0,688 \\
\hline $\begin{array}{l}C Y P 2 C 9 * 2 \\
\mathrm{wt} / \mathrm{wt} \\
\mathrm{wt} / * 2\end{array}$ & $\begin{array}{l}10 / 22(45,5) \\
1 / 2(50,0)\end{array}$ & 1,000 \\
\hline $\begin{array}{l}C Y P 2 C 9 * 3 \\
\mathrm{wt} / \mathrm{wt} \\
\mathrm{wt} / * 3\end{array}$ & $\begin{array}{l}10 / 21(47,6) \\
1 / 3(33,3)\end{array}$ & 1,000 \\
\hline $\begin{array}{l}A B C B 1 \\
\text { CC } \\
\text { CT } \\
\text { TT }\end{array}$ & $\begin{array}{l}1 / 5(20,0) \\
6 / 11(54,5) \\
4 / 8(50,0)\end{array}$ & 0,420 \\
\hline
\end{tabular}

Aprēķinos izmantots Chi-square tests. PRI3 - trešā VASP PRI analīze pēc otrās klopidogrela papildu PD saņemšanas. Iekavās norādīit procenti no kopējā pacientu skaita ar šādu genotipu.

\subsubsection{PRI4 rezultāti atkarībā no $C Y P 2 C 19, C Y P 2 C 9$ un $A B C B 1$ genotipiem}

Pacientu rezultāti, kuriem pēc klopidogrela standarta PD un divām papildu PD PRI $\geq 60 \%$ ( $n=11)$ un kuri bija saņēmuši trešo klopidogrela papildu PD, apkopoti 3.9. un 3.10. tabulā. 
Gan $C Y P 2 C 19 * 2$, gan $C Y P 2 C 19 * 17$ alēles nēsātājiem iepriekš esošās tendences praktiski bija izzudušas. To var izkaidrot ar nelielo pacientu skaitu, kuriem bija nepieciešama trešā klopidogrela papildu PD atbilstoši pētījuma devu stratēgijai.

3.9. tabula

Vidējās PRI4 un vidējās $\Delta$ PRI3-4 vērtības katrā genotipa grupā (n=11)

\begin{tabular}{|c|c|c|c|c|c|}
\hline Polimorfisms & $\mathbf{n}$ & $\begin{array}{l}\text { Vid. PRI4, \% } \\
\text { (SD) }\end{array}$ & $\mathbf{p}$ & $\begin{array}{l}\text { Vid. } \triangle \text { PRI3- } \\
\text { PRI4, \%p (SD) }\end{array}$ & $\mathbf{p}$ \\
\hline $\begin{array}{l}\text { СУР2С19*2 } \\
\text { wt/wt } \\
\text { wt/*2 un } * 2 / * 2\end{array}$ & $\begin{array}{l}5 \\
6\end{array}$ & $\begin{array}{l}54,8(2,0) \\
57,2(14,7)\end{array}$ & 0,731 & $\begin{array}{l}11,0(5,7) \\
12,3(11,1)\end{array}$ & 0,814 \\
\hline $\begin{array}{l}\text { СYP2C19*17 } \\
\text { wt/wt } \\
\text { wt/*17un } * 17 / * 17\end{array}$ & $\begin{array}{l}6 \\
5\end{array}$ & $\begin{array}{l}57,0(10,4) \\
55,0(11,8)\end{array}$ & 0,775 & $\begin{array}{l}11,5(6,7) \\
12,0(11,4)\end{array}$ & 0,930 \\
\hline $\begin{array}{l}C Y P 2 C 9 * 2 \\
\mathrm{wt} / \mathrm{wt} \\
\mathrm{wt} / * 2\end{array}$ & $\begin{array}{l}10 \\
1\end{array}$ & $\begin{array}{l}57,2(10,4) \\
45,0(-)\end{array}$ & 0,292 & $\begin{array}{l}11,1(8,8) \\
18,0(-)\end{array}$ & 0,476 \\
\hline $\begin{array}{l}C Y P 2 C 9 * 3 \\
\text { wt } / \text { wt } \\
\text { wt } / * 3\end{array}$ & $\begin{array}{l}10 \\
1\end{array}$ & $\begin{array}{l}55,9(11,1) \\
58,0(-)\end{array}$ & 0,860 & $\begin{array}{l}11,3(9,0) \\
16,0(-)\end{array}$ & 0,630 \\
\hline $\begin{array}{l}A B C B 1 \\
\mathrm{CC} \\
\mathrm{CT} / \mathrm{TT}\end{array}$ & $\begin{array}{l}1 \\
10 \\
\end{array}$ & $\begin{array}{l}55,0(-) \\
56,2(11,1)\end{array}$ & 0,920 & $\begin{array}{l}6,0(-) \\
12,3(8,9)\end{array}$ & 0,516 \\
\hline
\end{tabular}

Aprēķinos izmantots neatkarīgo izlašu t-tests, attēloti vidējie rezultāti (SD). PRI4 - VASP PRI ceturtā analīze, \%p - procentpunkti, $\Delta$ PRI3-4 - izmaiṇas PRI rādītājos pēc trešās klopidogrela papildu PD saņemšanas. 
Trešās klopidogrela papildu PD efekts katrā genotipa grupā $(n=11)$

\begin{tabular}{|c|c|c|}
\hline Polimorfisms & $\begin{array}{l}\text { PRI4 } \geq 60 \%, \\
\text { n (\%) }\end{array}$ & $\mathbf{p}$ \\
\hline \multicolumn{3}{|l|}{ CYP2C19*2 } \\
\hline $\mathrm{wt} / \mathrm{wt}$ & $0 / 5(0,0)$ & 0,231 \\
\hline $\mathrm{wt} / * 2$ & $2 / 5(40,0)$ & \\
\hline$* 2 / * 2$ & $0 / 1(0,0)$ & \\
\hline \multicolumn{3}{|l|}{ СУР 2 C19*17 } \\
\hline $\mathrm{wt} / \mathrm{wt}$ & $1 / 6(16,7)$ & 0,837 \\
\hline $\mathrm{wt} / * 17$ & $1 / 4(25,0)$ & \\
\hline$* 17 / * 17$ & $0 / 1(0,0)$ & \\
\hline \multicolumn{3}{|l|}{$C Y P 2 C 9 * 2$} \\
\hline $\mathrm{wt} / \mathrm{wt}$ & $2 / 10(20,0)$ & 1,000 \\
\hline $\mathrm{wt} / * 2$ & $0 / 1(0,0)$ & \\
\hline \multicolumn{3}{|l|}{$C Y P 2 C 9 * 3$} \\
\hline $\mathrm{wt} / \mathrm{wt}$ & $2 / 10(20,0)$ & 1,000 \\
\hline $\mathrm{wt} / * 3$ & $0 / 1(0,0)$ & \\
\hline \multicolumn{3}{|l|}{$A B C B 1$} \\
\hline $\mathrm{CC}$ & $0 / 1(0,0)$ & 0,837 \\
\hline $\mathrm{CT}$ & $1 / 6(16,7)$ & \\
\hline TT & $1 / 4(25,0)$ & \\
\hline
\end{tabular}

Aprēķinos izmantots Chi-square tests. PRI4 - ceturtā VASP PRI analīze pēc trešās klopidogrela papildu PD saņemšanas. Iekavās norādīti procenti no kopējā pacientu skaita ar šādu genotipu.

\subsubsection{0. un 40. dienas apsekošanas vizītes PRI rezultāti atkarībā no CYP2C19, $C Y P 2 C 9$ un $A B C B 1$ genotipiem}

CYP2C19*2 vismaz vienas samazinātas funkcijas alēles nēsātājiem $(\mathrm{wt} / * 2$ un *2/*2), kuriem PRI1 $\geq 60 \%$, desmit dienu FUP vizītē PRI bija statistiski ticami augstāks, saņemot klopidogrela palielinātu UD (150 mg/dienā), salīdzinot ar šī genotipa neizmainītas funkcijas alēles homozigotiem $(53,3 \pm 12,1$ un 40,3 $\pm 13,5 ; p=0,001)$. Š tendence saglabājās arī 40. dienas FUP vizītes laikā, lietojot klopidogrelu devā 75 $\mathrm{mg} /$ dienā, attiecīgi $65,5 \pm 10,4$ un 56,3 $\pm 14,5 ; \mathrm{p}=0,020$ (skat. 3.11. un 3.13. tabulu). Gan 10. dienas, gan 40. dienas apsekošanas vizīšu laikā klopidogrela hiporesponsivitātes 
grupā biežāk bija pacienti ar vismaz vienu $C Y P 2 C 19 * 2$ samazinātas funkcijas alēli. (skat. 3.12. līdz 3.14. tabulu). Pārējo genotipu starpā netika novērotas statistiski ticamas PRI atšķirības (skat. 3.11. līdz 3.14. tabulu).

3.11. tabula

\section{Klopidogrela 150mg UD efekts polimorfismu genotipu grupās $\left(n=65^{* *}\right)$}

\begin{tabular}{lll}
\hline Polimorfisms & PRI FU10, \% (SD) & p \\
\hline CYP2C19*2 & & \\
wt/wt & $40,3(13,5)$ & $\mathbf{0 , 0 0 1}$ \\
$\mathrm{wt} / * 2$ & $51,9(10,9)$ & \\
$* 2 / * 2$ & $76,0(-)$ & \\
CYP2C19*3 & & 0,362 \\
$\mathrm{wt} / \mathrm{wt}$ & $43,1(14,6)$ & \\
$\mathrm{wt} / * 3$ & $47,8(11,8)$ & \\
& & \\
$C Y P 2 C 19 * 17$ & & \\
$\mathrm{wt} / \mathrm{wt}$ & $45,5(15,1)$ & \\
$\mathrm{wt} / * 17$ & $42,1(14,6)$ & \\
$* 17 / * 17$ & $43,3(9,7)$ & \\
& & 0,805 \\
$C Y P 2 C 9 * 2$ & $43,8(13,8)$ & \\
$\mathrm{wt} / \mathrm{wt}$ & $42,0(23,0)$ & \\
$\mathrm{wt} / * 2$ & & \\
& & \\
$C Y P 2 C 9 * 3$ & $43,1(14,6)$ & \\
$\mathrm{wt} / \mathrm{wt}$ & $47,8(11,8)$ & \\
$\mathrm{wt} / * 3$ & & \\
$A B C B 1$ & $45,6(12,0)$ & \\
$\mathrm{CC}$ & $42,1(15,1)$ & \\
$\mathrm{CT}$ & $46,2(14,2)$ & \\
$\mathrm{TT}$ & & \\
& &
\end{tabular}

Aprēkininos izmantots neatkarīgo izlašu t-tests (2 grupām) un one-way ANOVA variācijas analīze (3 grupām), attēloti vidējie rezultāti (SD). PRI FU10 - 10. dienas apsekošanas PRI analīze; ** - analīzē nav iekḷauti pacienti, kuri saṇēma tikagrelora terapiju. 
Klopidogrela 150mg UD efekts polimorfismu genotipu grupās

\begin{tabular}{|c|c|c|}
\hline Polimorfisms & $\begin{array}{l}\text { PRI FU10 } \geq 60 \% \text {, } \\
\text { n (\%) }\end{array}$ & $\mathbf{p}$ \\
\hline $\begin{array}{l}\text { CYP2C19*2 } \\
\mathrm{wt} / \mathrm{wt} \\
\mathrm{wt} / * 2 \\
* 2 / * 2\end{array}$ & $\begin{array}{l}3 / 48(6,3) \\
4 / 16(25,0) \\
1 / 1(100,0)\end{array}$ & 0,004 \\
\hline $\begin{array}{l}\text { CYP2C19*3 } \\
\mathrm{wt} / \mathrm{wt} \\
\mathrm{wt} / * 3\end{array}$ & $\begin{array}{l}8 / 64(12,5) \\
0 / 1(0,0)\end{array}$ & 1,000 \\
\hline $\begin{array}{l}\text { CYP2C19*17 } \\
\text { wt/wt } \\
\text { wt/*17 } \\
* 17 / * 17\end{array}$ & $\begin{array}{l}5 / 28(17,9) \\
3 / 29(10,3) \\
0 / 8(0,0)\end{array}$ & 0,363 \\
\hline $\begin{array}{l}C Y P 2 C 9 * 2 \\
w t / w t \\
w t / * 2\end{array}$ & $\begin{array}{l}7 / 61(11,5) \\
1 / 4(25,0)\end{array}$ & 0,417 \\
\hline $\begin{array}{l}C Y P 2 C 9 * 3 \\
w t / w t \\
w t / * 3\end{array}$ & $\begin{array}{l}7 / 56(12,5) \\
1 / 9(11,1)\end{array}$ & 1,000 \\
\hline $\begin{array}{l}A B C B 1 \\
\text { CC } \\
\text { CT } \\
\text { TT }\end{array}$ & $\begin{array}{l}1 / 11(9,1) \\
4 / 35(11,4) \\
3 / 19(15,8)\end{array}$ & 0,842 \\
\hline
\end{tabular}

Aprēkinos izmantots Chi-square tests, iekavās norādīti procenti no kopējā pacientu skaita ar šādu genotipu, PRI FU10 - 10. dienas apsekošanas PRI analīze; ** - analīzē nav iekḷauti pacienti, kuri saṇēma tikagrelora terapiju. 
3.13. tabula

Klopidogrela 75mg UD efekts polimorfismu genotipu grupās pacientiem ar

$$
\text { PRI1 } \geq 60 \%(n=65) * *
$$

\begin{tabular}{|c|c|c|}
\hline Polimorfisms & PRI FU40, \% (SD) & $\mathbf{p}$ \\
\hline $\begin{array}{l}\text { CYP2C19*2 } \\
\mathrm{wt} / \mathrm{wt} \\
\mathrm{wt} / * 2 \\
* 2 / * 2\end{array}$ & $\begin{array}{l}56,3(14,5) \\
64,7(10,2) \\
78,0(-)\end{array}$ & $\mathbf{0 , 0 4 3}$ \\
\hline $\begin{array}{l}\text { CYP2C19*3 } \\
\mathrm{wt} / \mathrm{wt} \\
\mathrm{wt} / * 3\end{array}$ & $\begin{array}{l}59,5(13,7) \\
53,7(15,8)\end{array}$ & 0,247 \\
\hline $\begin{array}{l}\text { CYP2C19*17 } \\
\mathrm{wt} / \mathrm{wt} \\
\mathrm{wt} / * 17 \\
* 17 / * 17\end{array}$ & $\begin{array}{l}58,7(11,8) \\
59,0(16,2) \\
57,9(14,3)\end{array}$ & 0,982 \\
\hline $\begin{array}{l}C Y P 2 C 9 * 2 \\
w t / w t \\
w t / * 2\end{array}$ & $\begin{array}{l}59,0(14,3) \\
55,0(9,6)\end{array}$ & 0,588 \\
\hline $\begin{array}{l}\text { CYP2C9*3 } \\
w t / w t \\
w t / * 3\end{array}$ & $\begin{array}{l}59,5(13,7) \\
53,7(15,8)\end{array}$ & 0,247 \\
\hline $\begin{array}{l}A B C B 1 \\
\text { CC } \\
\text { CT } \\
\text { TT }\end{array}$ & $\begin{array}{l}62,1(13,6) \\
58,1(14,0) \\
57,9(14,8)\end{array}$ & 0,688 \\
\hline
\end{tabular}

Aprēķinos izmantots neatkarīgo izlašu t-tests (2 grupām) un one-way ANOVA variācijas analīze (3 grupām), attēloti vidējie rezultāti (SD). PRI FU40 - 40. dienas apsekošanas PRI analīze; ** - analīzē nav iekḷauti pacienti, kuri saṇēma tikagrelora terapiju. 
Klopidogrela 75mg UD efekts polimorfismu genotipu grupās pacientiem ar PRI1 $\geq 60 \%$

$$
(\mathbf{n}=\mathbf{6 5}) * *
$$

\begin{tabular}{|c|c|c|}
\hline Polimorfisms & $\begin{array}{l}\text { PRI FU40 } \geq 60 \%, \\
\text { n (\%)* }\end{array}$ & $\mathbf{p}$ \\
\hline $\begin{array}{l}C Y P 2 C 19 * 2 \\
\mathrm{wt} / \mathrm{wt} \\
\mathrm{wt} / * 2 \\
* 2 / * 2\end{array}$ & $\begin{array}{l}20 / 48(41,7) \\
12 / 16(75,0) \\
1 / 1(100,0)\end{array}$ & 0,042 \\
\hline $\begin{array}{l}\text { CYP2C19*3 } \\
\mathrm{wt} / \mathrm{wt} \\
\mathrm{wt} / * 3\end{array}$ & $\begin{array}{l}32 / 64(50,0) \\
1 / 1(100,0)\end{array}$ & 1,000 \\
\hline $\begin{array}{l}\text { CYP2C19*17 } \\
\text { wt/wt } \\
\text { wt/*17 } \\
* 17 / * 17\end{array}$ & $\begin{array}{l}13 / 28(46,4) \\
16 / 29(55,2) \\
4 / 8(50,0)\end{array}$ & 0,803 \\
\hline $\begin{array}{l}C Y P 2 C 9 * 2 \\
w t / w t \\
w t / * 2\end{array}$ & $\begin{array}{l}32 / 61(52,5) \\
1 / 4(25,0)\end{array}$ & 0,355 \\
\hline $\begin{array}{l}C Y P 2 C 9 * 3 \\
\mathrm{wt} / \mathrm{wt} \\
\mathrm{wt} / * 3\end{array}$ & $\begin{array}{l}30 / 56(53,6) \\
3 / 9(33,3)\end{array}$ & 0,303 \\
\hline $\begin{array}{l}A B C B 1 \\
\text { CC } \\
\text { CT } \\
\text { TT }\end{array}$ & $\begin{array}{l}5 / 11(45,5) \\
20 / 35(57,1) \\
8 / 19(42,1)\end{array}$ & 0,532 \\
\hline
\end{tabular}

Aprēķinos izmantots Chi-square tests, iekavās norādīti procenti no kopējā pacientu skaita ar šādu genotipu, PRI FU10 - 10. dienas apsekošanas PRI analīze; ** - analīzē nav iekḷauti pacienti, kuri saņēma tikagrelora terapiju.

Analizējot visu pētījumā iekļauto pacientu PRI atšķirības atkarībā no genotipa 40. dienas FUP vizītes laikā, redzams, ka CYP2C19*2 samazinātas funkcijas alēles nēsātajiem tendence PRI būt augstākam saglabājas statistiski ticama $(p=0,006)$, ko nenovēro pārējo analizēto genotipu polimorfismu grupās (skat. 3.15. un 3.16. tabulu). Visā pētījuma pacientu grupā PRI FU40 bija augstāks pacientiem ar vismaz vienu CYP2C19*2 samazinātas funkcijas alēli, lietojot klopidogrela UD $75 \mathrm{mg} / \mathrm{dienā}$ $(63,1 \pm 11,3$ un $50,3 \pm 17,1 ; p=0,002)$. Mērķa PRI $<60 \%$ gan ar klopidogrela palielinātu 
UD, gan ar standarta UD statistiski ticami retāk tika sasniegts $C Y P 2 C 19 * 2$ samazinātas funkcijas alēles nēsātājiem, salīdzinot ar neizmainītas funkcijas alēles nēsātājiem, attiecīgi ar UD $150 \mathrm{mg} /$ dienā 70,6\% un 93,8\%; p=0,024 un ar UD 75 mg/dienā 23,5\% un $58,5 \% ; \mathrm{p}=0,014$.

Klopidogrela 75mg UD efekts polimorfismu genotipu grupās (n=91)**

\begin{tabular}{|c|c|c|}
\hline Polimorfisms & PRI FU40, \% (SD) & $\mathbf{p}$ \\
\hline $\begin{array}{l}C Y P 2 C 19 * 2 \\
\mathrm{wt} / \mathrm{wt} \\
\mathrm{wt} / * 2 \\
* 2 / * 2\end{array}$ & $\begin{array}{l}50,3(17,1) \\
62,3(11,0) \\
78,0(-)\end{array}$ & 0,006 \\
\hline $\begin{array}{l}\text { CYP2C19*3 } \\
\mathrm{wt} / \mathrm{wt} \\
\mathrm{wt} / * 3\end{array}$ & $\begin{array}{l}52,8(16,6) \\
81,0(-)\end{array}$ & 0,095 \\
\hline $\begin{array}{l}\text { CYP2C19*17 } \\
\text { wt/wt } \\
\text { wt/*17 } \\
* 17 / * 17\end{array}$ & $\begin{array}{l}53,4(15,4) \\
52,8(18,6) \\
53,5(14,6)\end{array}$ & 0,984 \\
\hline $\begin{array}{l}C Y P 2 C 9 * 2 \\
\text { wt/wt } \\
w t / * 2\end{array}$ & $\begin{array}{l}53,7(17,0) \\
45,7(13,5)\end{array}$ & 0,228 \\
\hline $\begin{array}{l}C Y P 2 C 9 * 3 \\
\text { wt/wt } \\
\text { wt } / * 3\end{array}$ & $\begin{array}{l}53,9(16,8) \\
48,8(17,0)\end{array}$ & 0,299 \\
\hline $\begin{array}{l}A B C B 1 \\
\text { CC } \\
\text { CT } \\
\text { TT }\end{array}$ & $\begin{array}{l}57,7(16,1) \\
51,3(17,2) \\
53,6(16,5)\end{array}$ & 0,404 \\
\hline
\end{tabular}

Aprēḳinos izmantots neatkarīgo izlašu t-tests (2 grupām) un one-way ANOVA variācijas analīze (3 grupām), attēloti vidējie rezultāti (SD). PRI FU40 - 40. dienas apsekošanas PRI analīze; ** - analīzē nav iekḷauti pacienti, kuri saṇēma tikagrelora terapiju. 
Klopidogrela 75mg UD efekts polimorfismu genotipu grupās $(\mathbf{n}=91) * *$

\begin{tabular}{|c|c|c|}
\hline Polimorfisms & $\begin{array}{l}\text { PRI FU40 } \geq 60 \%, \\
\text { n (\%) }\end{array}$ & $\mathbf{p}$ \\
\hline \multicolumn{3}{|l|}{ CYP2C19*2 } \\
\hline wt/wt & $22 / 71(31,0)$ & 0,017 \\
\hline $\mathrm{wt} / * 2$ & $12 / 19(63,2)$ & \\
\hline$* 2 / * 2$ & $1 / 1(100,0)$ & \\
\hline \multicolumn{3}{|l|}{ СYР $2 C 19 * 3$} \\
\hline wt/wt & $34 / 90(37,8)$ & 0,385 \\
\hline $\mathrm{wt} / * 3$ & $1 / 1(100,0)$ & \\
\hline \multicolumn{3}{|l|}{ СУР 2C19*17 } \\
\hline wt/wt & $13 / 35(37,1)$ & 0,955 \\
\hline $\mathrm{wt} / * 17$ & $18 / 45(40,0)$ & \\
\hline$* 17 / * 17$ & $4 / 11(36,4)$ & \\
\hline \multicolumn{3}{|l|}{$C Y P 2 C 9 * 2$} \\
\hline $\mathrm{wt} / \mathrm{wt}$ & $34 / 84(40,5)$ & 0,243 \\
\hline $\mathrm{wt} / * 2$ & $1 / 7(14,3)$ & \\
\hline \multicolumn{3}{|l|}{ CYP $2 C 9 * 3$} \\
\hline wt/wt & $31 / 77(40,3)$ & 0,554 \\
\hline$w t / * 3$ & $4 / 14(28,6)$ & \\
\hline \multicolumn{3}{|l|}{$A B C B 1$} \\
\hline $\mathrm{CC}$ & $6 / 17(35,3)$ & 0,882 \\
\hline $\mathrm{CT}$ & $20 / 49(40,8)$ & \\
\hline TT & $9 / 25(36,0)$ & \\
\hline
\end{tabular}

Aprēḳinos izmantots Chi-square tests, iekavās norādīti procenti no kopējā pacientu skaita ar šādu genotipu, PRI FU40 - 40. dienas apsekošanas PRI analīze; ** - analīzē nav iekḷauti pacienti, kuri saṇēma tikagrelora terapiju.

Veicot daudzmain̄̄go analīzi (MVA - multivariate analysis), ABLH abu FUP vizī̌su laikā bija statistiski ticami saistīts ar klopidogrela efektu atkarībā no CYP2C19*2 genotipa (skat. 3.17. un 3.18. tabulu). 
10. dienas FUP PRI rezultātu saistība ar CYP2C19*2, ņemot vērā citus riska faktorus

\begin{tabular}{lll}
\hline Mainīgais & $\mathbf{B}$ & $\mathbf{p}$ \\
\hline CYP2C19*2 & 9,674 & $\mathbf{0 , 0 0 2}$ \\
PRI1 & 0,168 & 0,308 \\
SPRI1-2 & $-0,351$ & $<\mathbf{0 , 0 0 1}$ \\
KMI & $-0,005$ & 0,985 \\
TG & 1,894 & 0,236 \\
Glikoze & $-0,426$ & 0,532 \\
ABLH & $-8,553$ & $\mathbf{0 , 0 1 9}$ \\
\hline
\end{tabular}

Analīzē izmantota multiplās lineārās regresijas metode. PRI1 - pirmā VASP PRI analīze pēc klopidogrela standarta PD saņemšanas, $\triangle \mathrm{PRI} 1-2$ - izmaiņas PRI rādītājos pēc pirmās klopidogrela papildu PD saṇemšanas (\%p), ĶMI - k̦ermen̦a masas indekss $\left(\mathrm{kg} / \mathrm{m}^{2}\right), \mathrm{TG}$ - triglicerīdi $(\mathrm{mmol} / \mathrm{l}), \mathrm{ABLH}$ - augsta blīvuma lipoproteīnu holesterīns.

3.18. tabula

40. dienas FUP PRI rezultātu saistība ar CYP2C19*2, ņemot vērā riska faktorus

\begin{tabular}{lll}
\hline Mainīgais & B & p \\
\hline CYP2C19*2 & 1,892 & 0,658 \\
PRI1 & 0,244 & 0,322 \\
$\Delta$ PRI1-2 & $-0,050$ & 0,711 \\
KMI & $-0,024$ & 0,956 \\
TG & $-1,304$ & 0,556 \\
Glikoze & $-0,721$ & 0,477 \\
ABLH & $-14,198$ & $\mathbf{0 , 0 1 1}$ \\
\hline
\end{tabular}

Analīzē izmanota multiplās lineārās regresijas metode. PRI1 - pirmā VASP PRI analīze pēc klopidogrela standarta PD saņemšanas, $\triangle$ PRI1-2 - izmaiņas PRI rādītājos pēc pirmās klopidogrela papildu PD saņemšanas (\%p), ĶMI - ķermeņa masas indekss $\left(\mathrm{kg} / \mathrm{m}^{2}\right), \mathrm{TG}$ - triglicerīdi (mmol/1), ABLH - augsta blīvuma lipoproteīnu holesterīns.

\subsubsection{PD skaits atkarībā no CYP2C19, CYP2C9 un $A B C B 1$ genotipiem}

PD skaita atkarība no ǵenētiskā polimorfisma analizēta 3.19. tabulā. Pacientiem ar vismaz vienu CYP2C19*2 samazinātas funkcijas alēli $(\mathrm{wt} / * 2$ un *2/*2) biežāk nepieciešamas vairākas atkārtotas papildu PD pētījuma mērķa sasniegšanai (PRI <60\%), salīdzinot ar neizmainītas funkcijas alēles nēsātājiem (wt/wt), attiecīgi PRI1, PRI2, 
PRI3, PRI4: $18,2 \%, 36,4 \%, 22,7 \%, 22,7 \%$ un $36,6 \%, 46,5 \%, 9,9 \%, 7,0 \% ; \mathrm{p}=0,043$. Pacientiem ar CYP2C19*2 normālu genotipu (wt/wt) visbiežāk nepieciešama tikai viena klopidogrela papildu PD (46,5\%), salīdzinot ar pacientiem ar šī genotipa samazinātas funkcijas alēlēm, kuriem bieži nepieciešama vēl trešā un ceturtā klopidogrela PD. Kopumā pacienti ar pētījumā analizēto genotipu gan samazinātas, gan neizmainītas funkcijas alēlēm biežāk bija grupā ar novērotu hiporesponsivitāti pēc standarta klopidogrela PD saņemšanas (skat. 3.10 līdz 3.13. attēlu), kas pamato klopidogrela papildu PD izmantošanu atbilstoši pētījuma stratēǵijai.

3.19. tabula

Saṇemto klopidogrela PD skaita salīdzinājums starp genotipiskām pacientu grupām $(\mathbf{n}=93)$

\begin{tabular}{|c|c|c|c|c|c|c|}
\hline Polimorfisms & $\begin{array}{l}\text { Genotips } \\
\text { (n) }\end{array}$ & $\begin{array}{l}\text { PD1, } \\
\text { n (\%)* }\end{array}$ & $\begin{array}{l}\text { PD2, } \\
\text { n (\%) }\end{array}$ & $\begin{array}{l}\text { PD3, } \\
\text { n (\%) }\end{array}$ & $\begin{array}{l}\text { PD4, } \\
\text { n (\%) }\end{array}$ & $\mathbf{p}$ \\
\hline \multirow{3}{*}{ CYP $2 C 19 * 2$} & GG (71) & $26(36,6)$ & $33(46,5)$ & $7(9,9)$ & $5(7,0)$ & 0,072 \\
\hline & AG (21) & $3(14,3)$ & $8(38,1)$ & $5(23,8)$ & $5(23,8)$ & \\
\hline & $\mathrm{AA}(1)$ & $1(100,0)$ & - & - & - & \\
\hline \multirow[t]{2}{*}{ СYP $2 C 19 * 2$} & GG (71) & $26(36,6)$ & $33(46,5)$ & $7(9,9)$ & $5(7,0)$ & 0,043 \\
\hline & $\begin{array}{l}\text { AG/AA } \\
(22)\end{array}$ & $4(18,2)$ & $8(36,4)$ & $5(22,7)$ & $5(22,7)$ & \\
\hline \multirow[t]{3}{*}{ СYР 2 C19*17 } & $\mathrm{CC}(36)$ & $9(25,0)$ & $14(47,2)$ & $5(13,9)$ & $5(13,9)$ & 0,852 \\
\hline & CT (46) & $18(39,1)$ & $18(39,1)$ & $6(13,0)$ & $4(8,7)$ & \\
\hline & TT (11) & $3(32,3)$ & $6(54,5)$ & $1(9,1)$ & $1(9,1)$ & \\
\hline \multirow[t]{2}{*}{ CYP $2 C 19 * 17$} & CC (36) & $9(25,0)$ & $17(47,2)$ & $5(13,9)$ & $5(13,9)$ & 0,643 \\
\hline & $\begin{array}{l}\mathrm{CT} / \mathrm{TT} \\
(57)\end{array}$ & $21(36,8)$ & $24(42,1)$ & $7(12,3)$ & $5(8,8)$ & \\
\hline \multirow[t]{2}{*}{$C Y P 2 C 9 * 2$} & CC (86) & $27(31,4)$ & $39(45,3)$ & $11(12,8)$ & $9(10,5)$ & 0,855 \\
\hline & CT (7) & $3(42,9)$ & $2(28,6)$ & $1(14,3)$ & $1(14,3)$ & \\
\hline \multirow[t]{2}{*}{$C Y P 2 C 9 * 3$} & AA (79) & $25(31,6)$ & $35(44,3)$ & $10(12,7)$ & $9(11,4)$ & 0,962 \\
\hline & CA (14) & $5(35,7)$ & $6(42,9)$ & $2(14,3)$ & $1(7,1)$ & \\
\hline \multirow[t]{3}{*}{$A B C B 1$} & CC (17) & $7(41,2)$ & $6(35,3)$ & $3(17,6)$ & $1(5,9)$ & 0,786 \\
\hline & CT (26) & $17(34,0)$ & $23(46,0)$ & $5(10,0)$ & $5(10,0)$ & \\
\hline & TT (50) & $6(23,1)$ & $12(46,2)$ & $4(15,4)$ & $4(15,4)$ & \\
\hline \multirow[t]{2}{*}{$A B C B 1$} & CC (17) & $7(41,2)$ & $6(35,3)$ & $3(17,6)$ & $1(5,9)$ & 0,637 \\
\hline & $\begin{array}{l}\mathrm{CT} / \mathrm{TT} \\
(76)\end{array}$ & $23(30,3)$ & $35(46,1)$ & $9(11,8)$ & $9(11,8)$ & \\
\hline
\end{tabular}

Aprēḳinos izmantots Chi-square tests, iekavās norādīti procenti no kopējā pacientu skaita ar šādu genotipu. PD1 - klopidogrela standarta piesātinošā deva; PD2, PD3, PD4 - attiecīgi pirmā, otrā, trešāa klopidogrela papildu piesātinošā deva. 


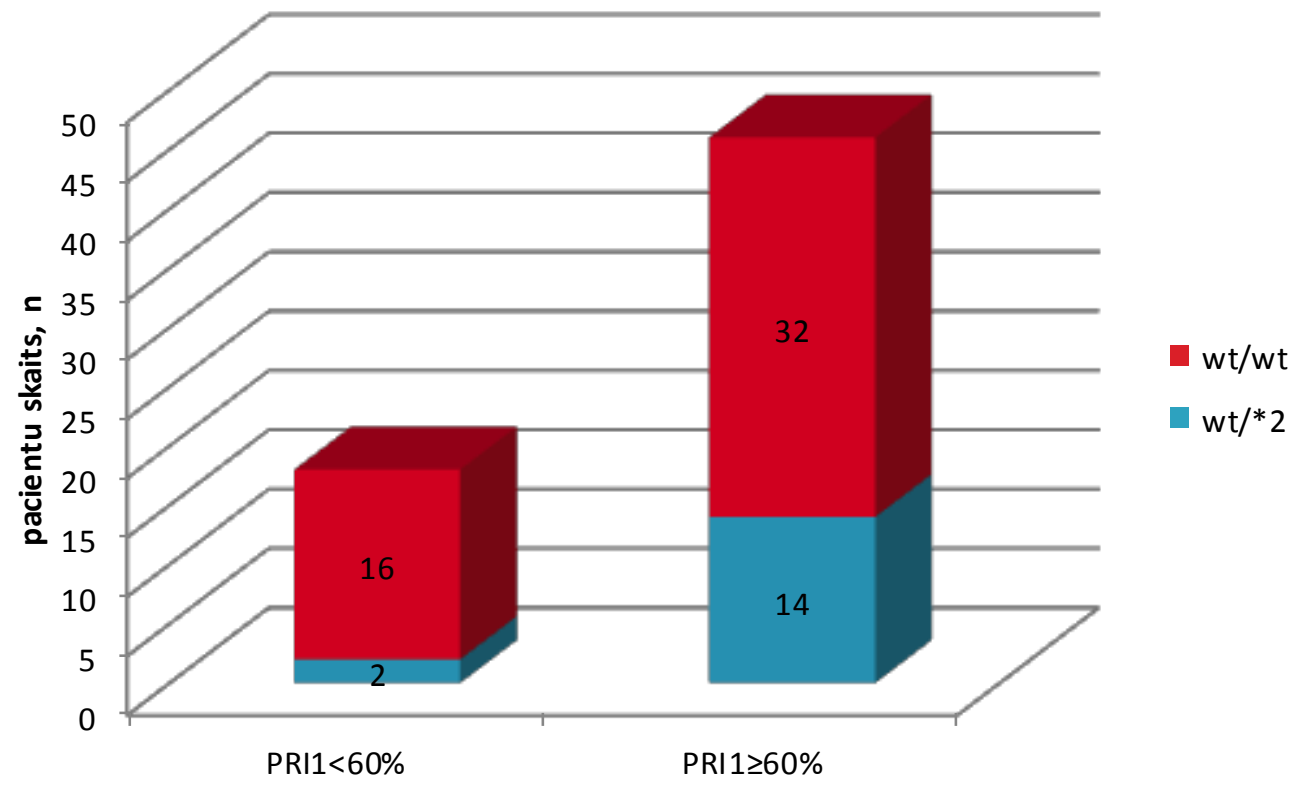

3.10. att. Pirmās klopidogrela $P D$ atšķirības no $C Y P 2 C 19 * 2$ genotipa

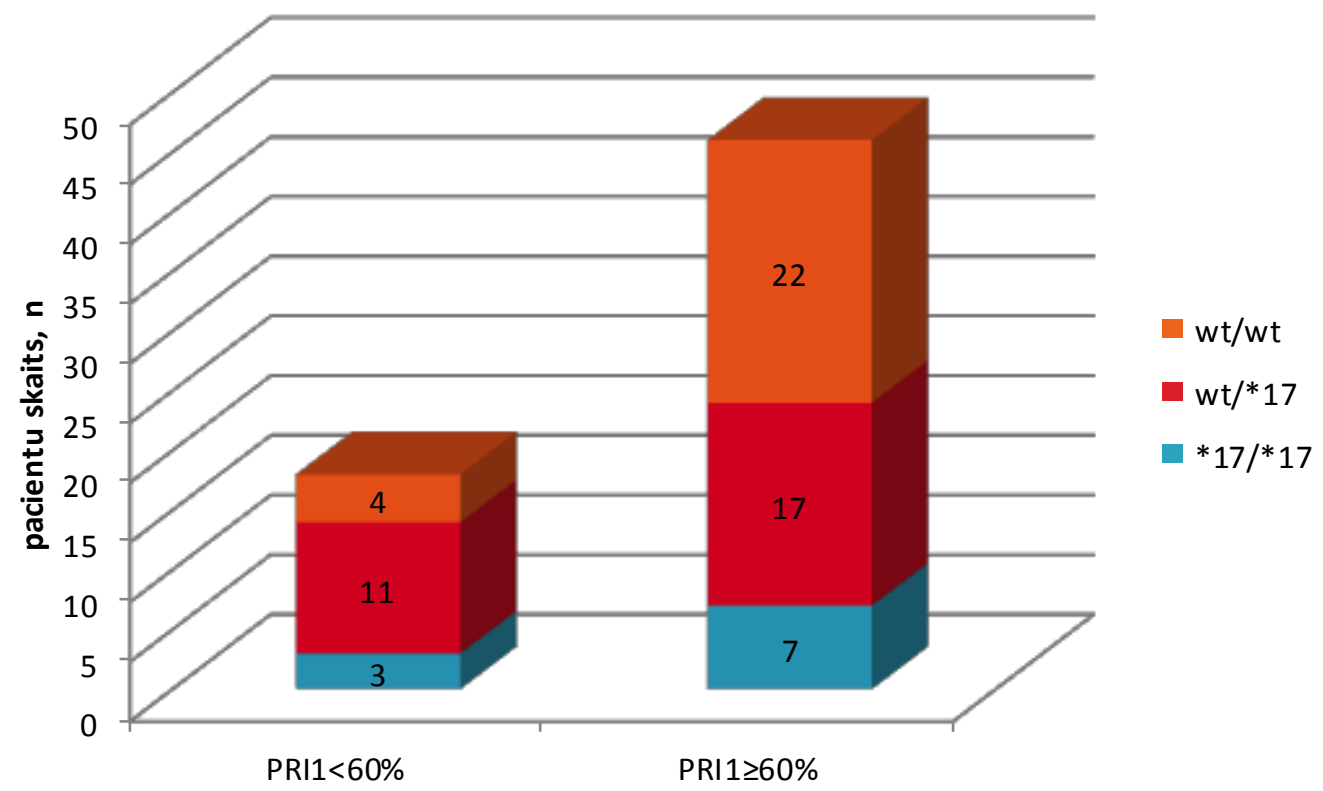

3.11. att. Pirmās klopidogrela PD atšķirības no CYP2C19*17 genotipa 


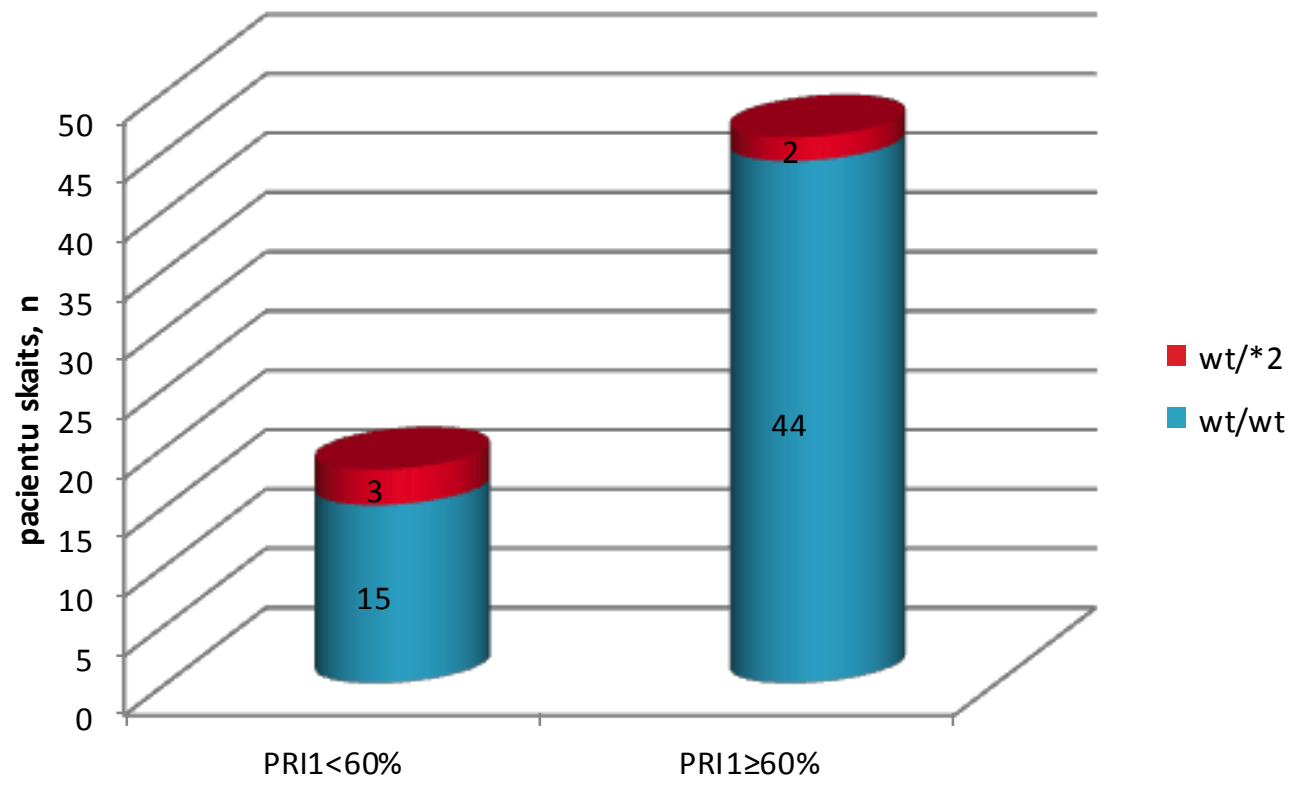

3.12.att. Pirmās klopidogrela PD atšķirības no CYP2C $9 * 2$ genotipa

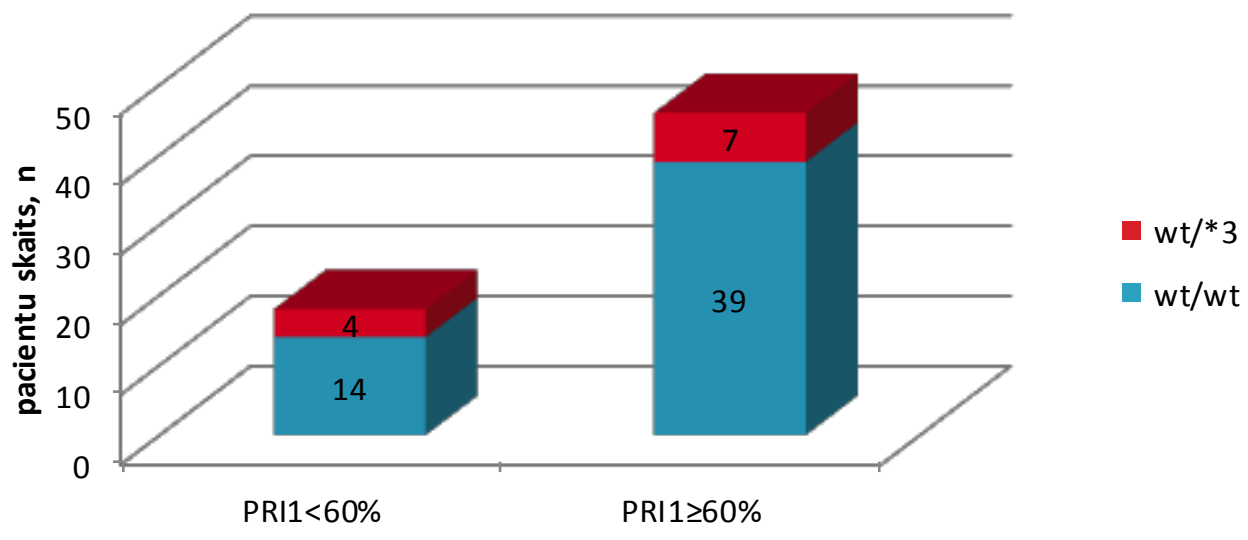

3.13.att. Pirmās klopidogrela PD atšķirības no CYP2C 9*3 genotipa

\subsection{Prehospitālās farmakoterapijas un esošu slimību ietekme uz PRI}

Analizējot pacientu prehospitāli lietoto zāḷu saistību ar PRI, novēroja, ka pacientiem, kuri iepriekš bija lietojuši klopidogrelu, bija raksturīgs zemāks vidējā PRI1 rezultāts $\pm \mathrm{SD}$, salīdzinot ar pacientiem bez iepriekš saņemtas klopidogrela terapijas, attiecīgi 49,8 $\pm 16,0$ un $69,7 \pm 18,4$. Izmantojot atkarīgo izlašu t-testu, tika secināts, ka vidējais PRI1 rezultāts pacientiem ar un bez klopidogrela terapijas prehospitālajā 
periodā atšks̄inās statistiski ticami $(\mathrm{t}=2,568 ; \mathrm{p}=0,012)$. Starp citu saņemto zâļ̧u prehospitālo terapiju un PRI1 rezultātu netika novērotas statistiski ticamas atšķirības (skat. 3.20. tabulu). Izmantojot dispersiju analīzi (ANOVA), tika secināts, ka PRI1 rezultāts statistiski ticami atšķīrās pie dažādām aspirīna devām $(\mathrm{F}=4,668 ; \mathrm{p}=0,005)$, savukārt pie dažādiem PSI tipiem netika novērota PRI1 rezultāta statistiski ticama atšķirība $(F=4,365 ; p=0,063)$.

3.20. tabula

PRI1 vidējā rezultāta variabilitāte atkarībā no prehospitālās farmakoterapijas

\begin{tabular}{|c|c|c|c|c|c|c|}
\hline $\begin{array}{l}\text { Prehospitālā } \\
\text { terapija }\end{array}$ & & $\begin{array}{l}\text { Pacientu } \\
\text { skaits (n) }\end{array}$ & $\begin{array}{l}\text { Vidējais } \\
\text { PRI1 }\end{array}$ & SD & $\mathbf{t}$ & $\mathbf{p}$ \\
\hline \multirow[t]{2}{*}{ Klopidogrels } & $\overline{j a ̄}$ & 6 & 49,8 & 16,0 & 2,568 & $\mathbf{0 , 0 1 2}$ \\
\hline & $n \overline{\mathrm{e}}$ & 88 & 69,7 & 18,4 & & \\
\hline \multirow[t]{2}{*}{ Aspirīns } & $\mathrm{jā}$ & 71 & 67,1 & 19,9 & 1,337 & 0,187 \\
\hline & $n \bar{e}$ & 23 & 72,3 & 14,8 & & \\
\hline \multicolumn{7}{|l|}{ (acetilsalicilskābe) } \\
\hline \multirow[t]{2}{*}{ PSI } & $\mathrm{jā}$ & 12 & 72,6 & 21,0 & 0,774 & 0,441 \\
\hline & $n \overline{\mathrm{e}}$ & 78 & 68,1 & 18,5 & & \\
\hline \multirow[t]{2}{*}{$\mathrm{BB}$} & jā & 65 & 70,1 & 19,2 & 1,181 & 0,244 \\
\hline & nē & 25 & 65,0 & 17,6 & & \\
\hline \multirow[t]{2}{*}{ Statīni } & $\mathrm{ja}$ & 68 & 68,8 & 20,0 & 0,145 & 0,885 \\
\hline & $\mathrm{ne}$ & 22 & 68,2 & 15,0 & & \\
\hline \multirow[t]{2}{*}{ KKB } & $\mathrm{j} \overline{\mathrm{a}}$ & 35 & 71,8 & 17,1 & 1,296 & 0,199 \\
\hline & $n \overline{\mathrm{e}}$ & 55 & 66,7 & 19,7 & & \\
\hline \multirow[t]{2}{*}{ AKEI un A2RB } & $\mathrm{jā}$ & 64 & 67,9 & 20,2 & 0,679 & 0,499 \\
\hline & $n \bar{e}$ & 26 & 70,5 & 15,0 & & \\
\hline \multirow[t]{2}{*}{ Nitrāti } & $\mathrm{jā}$ & 17 & 69,7 & 21,4 & 0,238 & 0,813 \\
\hline & $\mathrm{ne \overline { \textrm {e } }}$ & 73 & 68,4 & 18,3 & & \\
\hline
\end{tabular}

Aprēḳinos izmantots neatkarīgo izlašu t-tests, attēloti vidējie rezultāti (SD). PSI - protonu sūkṇa inhibitori, BB - beta blokatori, KKB - kalcija kanālu blokatori, AKEI - angiotenzīna konvertējošā enzīma inhibitori, A2RB - angiotenzīna II receptoru blokatori.

Tika veikta arī PRI1 vidējo rezultātu analīze atkarībā no pacientu slimībām anamnēzē. Izmantojot atkarīgo izlašu t-testu, tika secināts, ka vidējais PRI1 rezultāts pacientiem ar un bez insulta atšksīrās statistiski ticami $(\mathrm{t}=2,106 ; \mathrm{p}=0,038)$. Starp citām pacientiem esošām slimībām un PRI1 rezultātu netika novērotas statistiski ticamas atšksirības (skat. 3.21. tabulu). 
PRI1 vidējā rezultāta variabilitāte atkarībā no pacientu klīniskām diagnozēm

\begin{tabular}{|c|c|c|c|c|c|c|}
\hline \multicolumn{2}{|c|}{ Klīniskā diagnoze } & \multirow{2}{*}{$\begin{array}{l}\begin{array}{l}\text { Pacientu } \\
\text { skaits (n) }\end{array} \\
28\end{array}$} & \multirow{2}{*}{$\begin{array}{l}\begin{array}{l}\text { Vidējais } \\
\text { PRI1 }\end{array} \\
66,5\end{array}$} & \multirow{2}{*}{$\begin{array}{l}\text { SD } \\
21,9\end{array}$} & \multirow{2}{*}{$\begin{array}{l}\mathbf{t} \\
0,629\end{array}$} & \multirow{2}{*}{$\begin{array}{l}\mathbf{p} \\
0,531\end{array}$} \\
\hline $\mathrm{CD}$ & jā & & & & & \\
\hline & nē & 66 & 69,2 & 17,5 & & \\
\hline \multirow[t]{2}{*}{ MI } & $\mathrm{jā}$ & 33 & 68.3 & 17,9 & 0,030 & 0,976 \\
\hline & nē & 61 & 68,4 & 19,5 & & \\
\hline \multirow[t]{2}{*}{ PCI } & jā & 30 & 65,8 & 19,2 & 0,898 & 0,372 \\
\hline & nē & 64 & 69,6 & 18,7 & & \\
\hline \multirow[t]{2}{*}{ HSM } & jā & 59 & 70,2 & 18,8 & 1,278 & 0,204 \\
\hline & nē & 33 & 65,0 & 19,2 & & \\
\hline \multirow[t]{2}{*}{$\mathrm{AH}$} & jā & 84 & 68,9 & 19,2 & 0,705 & 0,482 \\
\hline & nē & 8 & 63,9 & 17,9 & & \\
\hline \multirow[t]{2}{*}{ HNS } & $\mathrm{jā}$ & 2 & 67,5 & 12,0 & 0,052 & 0,958 \\
\hline & nē & 89 & 68,2 & 19,2 & & \\
\hline \multirow[t]{2}{*}{$\mathrm{CI}$} & $\mathrm{jā}$ & 6 & 53,0 & 24,6 & 2,106 & $\mathbf{0 , 0 3 8}$ \\
\hline & nē & 88 & 69,4 & 18,1 & & \\
\hline
\end{tabular}

Aprēķinos izmantots neatkarīgo izlašu t-tests, attēloti vidējie rezultāti (SD). CD - cukura diabēts, MI - miokarda infarkts, PCI - perkutāna koronāra intervence, HSM - hroniska sirds mazspēja, AH arteriāla hipertensija, HNS - hroniska nieru slimība, CI - cerebrāls infarkts.

\subsection{Vispārējo un anamnnēzes datu salīdzinājums atkarībā no PRI1}

Atsevišķu pamata demogrāfisko faktoru, anamnēzes un lietoto medikamentu ziņā vērojamas statistiski ticamas atšķirības starp pacientiem ar paaugstinātu PRI1 $\geq 60 \%$ un pacientiem ar PRI1 $<60 \%$ pēc klopidogrela standarta PD saņemšanas (skat. 3.22. tabulu). Pacientiem ar PRI1 $\geq 60 \%$ novēroja lielāku ĶMI, attiecīgi $30,7 \pm 4,8 \mathrm{~kg} / \mathrm{m}^{2}$ un $27,1 \pm 2,8 \mathrm{~kg} / \mathrm{m}^{2}(\mathrm{p}=0,001)$, statistiski ticami biežāk novēroja arī adipozitāti, attiecīgi $35(51,5 \%)$ un $5(19,2 \%)$ pacientiem $(\mathrm{p}=0,005)$. Pacientu grupā ar PRI1 <60\% biežāk bija pacienti, kuri jau pirms PCI ambulatori bija lietojuši klopidogrelu, attiecīgi $5(19,2 \%)$ un $1(1,5 \%)$ pacients $(\mathrm{p}=0,006)$. Pacientu grupā ar PRI1 $\geq 60 \%$ novēroja statistiski ticamu tendenci biežākai PSI lietošanai $(\mathrm{p}=0,046)$. Lai gan pantoprazola lietotāju skaits abās grupās bija vienāds $(n=3)$, visi pacienti, kuri ambulatori bija saņēmuši omeprazolu, bija grupā ar PRI1 $\geq 60 \%$. Omega-3 taukskābes biežāk ambulatori bija lietojuši pacienti no grupas ar PRI1 $<60 \%(\mathrm{n}=8 ; 33,3 \%)$, salīdzinot ar pacientu grupu ar PRI $\geq 60 \%(\mathrm{n}=8 ; 12,3 \%)$ $(\mathrm{p}=0,022)$. Starp citiem ambulatori lietotiem medikamentiem un PRI grupām 
nenovēroja būtiskas atšķirības. Citas statistiski ticamas atšķirības starp trombocītu reaktivitāti un intrahospitālo terapiju, laboratoriskiem raksturlielumiem netika novērotas.

Vispārējie un anamnēzes dati pacientiem ar PRI1 $\geq 60 \%$ un PRI1 $<60 \%$

\begin{tabular}{|c|c|c|c|}
\hline & $\begin{array}{l}\text { PRI1<60\% } \\
(n=26)\end{array}$ & $\begin{array}{l}\text { PRI1 } \geq 60 \% \\
(n=68)\end{array}$ & $\mathbf{p}$ \\
\hline $\begin{array}{l}\text { Vecums (gadi), } \\
\text { vidējais } \pm \text { SD }\end{array}$ & $63,6 \pm 10,9$ & $62,8 \pm 9,2$ & 0,713 \\
\hline Vīrieši, n (\%) & $13(50,0)$ & $37(54,4)$ & 0,701 \\
\hline ĶMI $\left(\mathrm{kg} / \mathrm{m}^{2}\right)$, vidējais $\pm \mathrm{SD}$ & $27,1 \pm 2,8$ & $30,7 \pm 4,8$ & 0,001 \\
\hline $\begin{array}{l}\text { Adipozitāte } \\
\left(\text { ĶMI }>30 \mathrm{~kg} / \mathrm{m}^{2}\right), \mathrm{n}(\%)\end{array}$ & $5(19,2)$ & $35(51,5)$ & 0,005 \\
\hline MI anamnēzē, n (\%) & $8(30,8)$ & $25(36,8)$ & 0,586 \\
\hline HSM, n (\%) & $15(57,7)$ & $44(66,7)$ & 0,473 \\
\hline NYHA I & $7(46,7)$ & $11(25,0)$ & \\
\hline NYHA II & $8(53,3)$ & $30(68,2)$ & 0,209 \\
\hline NYHA III & - & $3(6,8)$ & \\
\hline CABG, n (\%) & $1(3,8)$ & $1(1,5)$ & 0,643 \\
\hline \multicolumn{4}{|c|}{ Kardiovaskulārie riska faktori, n (\%) } \\
\hline Aktīvs smēķētājs & $2(7,7)$ & $9(13,4)$ & 0,556 \\
\hline $\mathrm{CD}$ & $9(34,6)$ & $19(27,9)$ & 0,527 \\
\hline $\mathrm{AH}$ & $24(92,3)$ & $60(89,6)$ & 0,803 \\
\hline I pakāpe & $5(23,8)$ & $9(16,1)$ & \\
\hline II pakāpe & $16(76,2)$ & $42(75,0)$ & 0,304 \\
\hline III pakāpe & - & $5(8,9)$ & \\
\hline \multicolumn{4}{|l|}{ PCI indikācija, n (\%) } \\
\hline Stabila KSS & $23(88,5)$ & $52(76,5)$ & 0,258 \\
\hline Nestabila stenokardija & $2(7,7)$ & $7(10,3)$ & \\
\hline STEMI & - & $8(11,8)$ & \\
\hline NSTEMI & $1(3,8)$ & $1(1,5)$ & \\
\hline
\end{tabular}




\begin{tabular}{|c|c|c|c|}
\hline & $\begin{array}{l}\text { PRI1<60\% } \\
(n=26)\end{array}$ & PRI1 $\geq 60 \%(n=68)$ & $\mathbf{p}$ \\
\hline \multicolumn{4}{|c|}{ Lietoto zāḷu terapija, n (\%): prehospitāli } \\
\hline Aspirīns & $22(84,6)$ & $49(72,1)$ & 0,205 \\
\hline \multicolumn{4}{|l|}{ Aspirīna deva: } \\
\hline $50 \mathrm{mg} /$ dienā & $1(5,0)$ & - & \\
\hline $75 \mathrm{mg} /$ dienā & $3(15,0)$ & $12(25,5)$ & 0,098 \\
\hline 100 mg/dienā & $16(80,0)$ & $29(61,7)$ & \\
\hline $150 \mathrm{mg} /$ dienā & - & $6(12,8)$ & \\
\hline Klopidogrels & $5(19,2)$ & $1(1,5)$ & 0,006 \\
\hline PSI & $3(12,5)$ & $9(13,6)$ & 0,888 \\
\hline \multicolumn{4}{|l|}{ PSI tips: } \\
\hline Pantoprazols & $3(100,0)$ & $3(33,3)$ & 0,046 \\
\hline Omeprazols & - & $6(66,7)$ & \\
\hline Statīni & $18(75,0)$ & $50(75,8)$ & 0,941 \\
\hline BB & $17(70,8)$ & $48(72,7)$ & 0,859 \\
\hline AKEI un A2RB & $19(79,2)$ & $45(68,2)$ & 0,309 \\
\hline KKB & $7(29,2)$ & $28(42,4)$ & 0,254 \\
\hline Nitrāti & $4(16,7)$ & $13(19,7)$ & 0,745 \\
\hline Antiaritmiskie līdzekḷi & - & $1(1,5)$ & 0,544 \\
\hline Benzodiazepīni & $1(4,2)$ & $2(3,1)$ & 0,800 \\
\hline Omega-3 & $8(33,3)$ & $8(12,3)$ & $\mathbf{0 , 0 2 2}$ \\
\hline \multicolumn{4}{|l|}{ Intrahospitāli } \\
\hline PSI & $18(69,2)$ & $51(76,1)$ & 0,496 \\
\hline \multirow{2}{*}{$\begin{aligned} \text { PSI tips: } & \text { Pantoprazols } \\
& \text { Omeprazols }\end{aligned}$} & $16(88,9)$ & $41(80,4)$ & 0,662 \\
\hline & $2(11,1)$ & $9(17,6)$ & \\
\hline Statīni & $25(96,2)$ & $65(97,0)$ & 0,833 \\
\hline BB & $23(88,5)$ & $59(88,1)$ & 0,957 \\
\hline $\mathrm{AKE}$ un $\mathrm{A} 2 \mathrm{RB}$ & $22(84,6)$ & $62(92,5)$ & 0,246 \\
\hline KKB & $12(46,2)$ & $32(47,8)$ & 0,889 \\
\hline Nitrāti & $8(30,8)$ & $23(34,3)$ & 0,744 \\
\hline Antiaritmiskie līdzekḷi & $1(3,8)$ & $3(4,5)$ & 0,893 \\
\hline Benzodiazepīni & $5(19,2)$ & $7(10,4)$ & 0,257 \\
\hline Omega-3 & $1(9,1)$ & $6(20,7)$ & 0,389 \\
\hline \multicolumn{4}{|c|}{ Laboratoriskie raksturlielumi, vidējais $\pm \mathrm{SD}$} \\
\hline Leikocītu skaits, $10^{9} / 1$ & $7,5 \pm 1,5$ & $7,8 \pm 2,4$ & 0,445 \\
\hline Hemoglobīns, g/l & $1,4 \pm 1,2$ & $1,4 \pm 2,2$ & 0,591 \\
\hline Trombocitu skaits, $10^{3} / 1$ & $239,1 \pm 48,8$ & $219,1 \pm 53,0$ & 0,090 \\
\hline Fibrinogēns, g/l & $3,2 \pm 0,8$ & $3,4 \pm 1,4$ & 0,573 \\
\hline Kreatinīns, $\mu \mathrm{mol} / 1$ & $80,2 \pm 16,2$ & $84,5 \pm 26,1$ & 0,440 \\
\hline $\begin{array}{l}\text { Nieru filtrācijas ātrums, } \\
\mathrm{ml} / \mathrm{min}\end{array}$ & $55,8 \pm 15,3$ & $66,0 \pm 26,0$ & 0,063 \\
\hline
\end{tabular}




\begin{tabular}{|c|c|c|c|}
\hline & $\begin{array}{l}\text { PRI1<60\% } \\
(\mathrm{n}=26)\end{array}$ & PRI1 $\geq 60 \%(n=68)$ & $\mathbf{p}$ \\
\hline \multicolumn{4}{|c|}{ Laboratoriskie raksturlielumi, vidējais $\pm \mathrm{SD}$} \\
\hline $\mathrm{KH}, \mathrm{mmol} / \mathrm{l}$ & $4,3 \pm 1,1$ & $4,6 \pm 1,4$ & 0,297 \\
\hline $\mathrm{ABLH}, \mathrm{mmol} / \mathrm{l}$ & $1,3 \pm 0,4$ & $1,2 \pm 0,4$ & 0,649 \\
\hline ZBLH, mmol/1 & $2,5 \pm 0,9$ & $2,1 \pm 1,2$ & 0,404 \\
\hline $\mathrm{TG}, \mathrm{mmol} / \mathrm{l}$ & $1,2 \pm 0,7$ & $1,5 \pm 0,9$ & 0,179 \\
\hline \multicolumn{4}{|c|}{ Angiogrāfija and perkutāna koronāra intervence } \\
\hline $\begin{array}{l}\text { Laboto asinsvadu skaits } \\
\text { pacientam, vidējais } \pm \text { SD }\end{array}$ & $1,1 \pm 0,3$ & $1,0 \pm 0,2$ & 0,531 \\
\hline $\begin{array}{l}\text { Stentu skaits pacientam, } \\
\text { vidējais } \pm \text { SD }\end{array}$ & $1,4 \pm 0,6$ & $1,4 \pm 0,6$ & 0,987 \\
\hline $\begin{array}{l}\text { DES skaits pacientam, } \\
\text { vidējais } \pm \text { SD }\end{array}$ & $1,2 \pm 0,4$ & $1,2 \pm 0,5$ & 0,920 \\
\hline $\begin{array}{l}\text { GP IIb/IIIa inhibitoru } \\
\text { lietošana, } \mathrm{n}(\%)\end{array}$ & $12(46,2)$ & $32(47,8)$ & 0,889 \\
\hline
\end{tabular}

Aprēkininos izmantots neatkarīgo izlašu t-tests, attēlojot vidējos rezultātus(SD); Chi-square tests, iekavās norādīiti procenti no kopējā pacientu skaita konkrētā faktora grupā. ĶMI - ķermeņa masas indekss, CABG - koronāro artēriju šuntēšana, KSS - koronārā sirds slimība, STEMI - miokarda infarkts ar ST segmenta elevācijām, NSTEMI - miokarda infarkts bez ST segmenta elevācijām, CD - cukura diabēts, MI - miokarda infarkts, PCI - perkutāna koronāra intervence, HSM - hroniska sirds mazspēja, AH - arteriāla hipertensija, HNS - hroniska nieru slimība, CI - cerebrāls infarkts, PSI - protonu sūkña inhibitori, BB - beta blokatori, KKB - kalcija kanālu blokatori, AKEI - angiotenzīna konvertējošā enzīma inhibitori, A2RB - angiotenzīna II receptoru blokatori, KH - kopējais holesterīns, ABLH - augsta blīvuma lipoproteīnu holesterīns, ZBLH - zema blīvuma lipoproteīnu holesterīns, TG - triglicerīdi , DES - ar zālēm pārklāts stents, GP - glikoproteīns, SD - standartdeviācija.

\subsubsection{KMI ietekme uz klopidogrela papildu PD un augstāku UD efektivitāti}

Pēc pirmās klopidogrela papildu PD saņemšanas pacientiem ar hiporesponsivitāti novēroja lielāku vidējo ĶMI, attiecīgi $32,8 \pm 3,9 \mathrm{~kg} / \mathrm{m}^{2}$ un $29,6 \pm 4,9 \mathrm{~kg} / \mathrm{m}^{2}$ $(\mathrm{p}=0,007)$ (skat. 3.23. tabulu). Pacientiem pēc otrās un trešās klopidogrela papildu PD saņemšanas šî tendence saglabājās, lai gan nebija statistiski ticama. Pacientiem ar PRI FU10 $\geq 60 \%$ un PRI FU40 $\geq 60 \%$ bija augstāks ĶMI, salīdzinot ar otru grupu (PRIFU10 <60\% un PRI FU40 <60\% ) abu apsekošanas vizī̌su laikā.

Pacientiem ar adipozitāti $\left(\right.$ ĶMI $\left.\geq 30 \mathrm{~kg} / \mathrm{m}^{2}\right)$ biežāk novēroja neatbilstošu PRI pēc katras klopidogrela papildu PD saņemšanas, attiecīgi 19 (79,2\%), 9 (81,8\%) un $2(100 \%)$ pacientiem (skat. 3.24. tabulu). Pacientiem ar adipozitāti visas klopidogrela devu stratēǵijas laikā tika novērots augstāks PRI, salīdzinot ar pacientiem, kuriem ĶMI $<30 \mathrm{~kg} / \mathrm{m}^{2}$. Statistiski ticama atšķirība starp pacientu grupām ar adipozitāi vai bez tās tika novērota pēc klopidogrela standarta PD saņemšanas, attiecīgi 
62,7 vs 72,1 $(\mathrm{p}<0,001)$, kā arī pēc pirmās klopidogrela papildu PD, respektīvi 34,4 vs 55,5 ( $\mathrm{p}<0,001)$ (skat. 3.14. attēlu). Vidējais PRI samazinājums pēc pirmās klopidogrela papildu PD saņemšanas (vid. $\Delta$ PRI1-PRI2) bija statistiski ticami zemāks pacientu grupā ar ĶMI $\geq 30 \mathrm{~kg} / \mathrm{m}^{2}$, attiecīgi $26,0 \pm 15,8 \%$ p un $39,6 \pm 15,3 \% \mathrm{p}(\mathrm{p}=0,001)$. Gan augstāka, gan standarta UD šajā grupā bija mazāk efektīva, attiecīgi 62,5\% un $51,4 \%$ pacientu, salīdzinot ar grupu, kur ĶMI $<30 \mathrm{~kg} / \mathrm{m}^{2}$.

Balstoties uz to, ka palielināts ķermeņa svars bieži vien saistās arī ar vidukḷa apkārtmēra pieaugumu, tika analizēta tā saistība ar PRI. Lielāku vidējo vidukḷa apkārtmēru pēc klopidogrela standarta PD sņemšanas novēro pacientu grupā ar hipo-

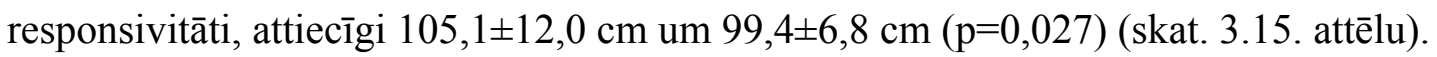

3.23. tabula

Vidējas KMI atšksirības pacientiem pēc klopidogrela papildu PD un abu UD saṇemšanas

\begin{tabular}{lcll}
\hline PRI, \% & n & Vid. KMI, $\mathbf{~ k g} / \mathbf{m}^{2}$ (SD) & p \\
\hline $\begin{array}{l}\text { PRI2 } \\
<60 \%\end{array}$ & 44 & $29,6(4,9)$ & $\mathbf{0 , 0 0 7}$ \\
$\geq 60 \%$ & 24 & $32,8(3,9)$ & \\
PRI3 & & & \\
$<60 \%$ & 13 & $32,4(3,9)$ & 0,580 \\
$\geq 60 \%$ & 11 & $33,3(4,0)$ & \\
PRI4 & & & 0,224 \\
$<60 \%$ & 9 & $32,5(3,7)$ & \\
$\geq 60 \%$ & 2 & $36,5(5,0)$ & 0,097 \\
PRI FU10 & & & \\
$<60 \%$ & 58 & $30,2(4,6)$ & 0,058 \\
$\geq 60 \%$ & 8 & $33,1(4,9)$ & \\
PRI FU40 & & & \\
$<60 \%$ & 59 & $29,0(4,7)$ & \\
$\geq 60 \%$ & 35 & $30,9(4,3)$ &
\end{tabular}

Aprēķinos izmantots neatkarīgo izlašu t-tests, attēloti vidējie rezultāti (SD). PRI2, PRI3, PRI4 attiecīgi VASP PRI analīze pēc pirmās, otrās un trešās klopidogrela papildu PD saņemšanas. PRI FU10 10. dienas apsekošanas PRI analīze, PRI FU40 - 40. dienas apsekošanas PRI analīze. 
Papildu klopidogrela PD un augstākas UD efektivitāte pacientiem ar adipozitāti

\begin{tabular}{llll}
\hline PRI, $\%$ & $\mathbf{K M I} \geq \mathbf{3 0} \mathbf{~ k g} \mathbf{m}^{\mathbf{2}}, \mathbf{n}(\mathbf{\%})$ & $\mathbf{K M I}<\mathbf{3 0} \mathbf{~ k g} / \mathbf{m}^{\mathbf{2}}, \mathbf{n}(\mathbf{\%})$ & $\mathbf{p}$ \\
\hline PRI2 & & & \\
$<60 \%$ & $16(36,4)$ & $28(63,6)$ & $\mathbf{0 , 0 0 1}$ \\
$\geq 60 \%$ & $19(79,2)$ & $5(20,8)$ & \\
PRI3 & & $3(23,1)$ & 1,000 \\
$<60 \%$ & $10(52,6)$ & $2(18,2)$ & \\
$\geq 60 \%$ & $9(81,8)$ & & 1,000 \\
PRI4 & & $2(22,2)$ & \\
$<60 \%$ & - & \\
$\geq 60 \%$ & $7(77,8)$ & & 0,708 \\
& $2(100,0)$ & $30(51,7)$ & \\
PRI FU10 & & $3(37,5)$ & \\
$<60 \%$ & $28(48,3)$ & & 0,201 \\
$\geq 60 \%$ & $5(62,5)$ & $37(62,7)$ & \\
PRI FU40 & & $17(48,6)$ & \\
$<60 \%$ & $22(37,3)$ & & \\
$\geq 60 \%$ & $18(51,4)$ & & \\
\hline
\end{tabular}

Aprēķinos izmantots Chi-square tests, attēlojot pscientu skaitu un \% konkrētā grupā. ĶMI kermeña masas indekss, PRI2, PRI3, PRI4 attiecīgi VASP PRI analīze pēc pirmās, otrās un trešās klopidogrela papildu PD saņemšanas. PRI FU10 - 10. dienas apsekošanas PRI analīze, PRI FU40 - 40. dienas apsekošanas PRI analīze. 


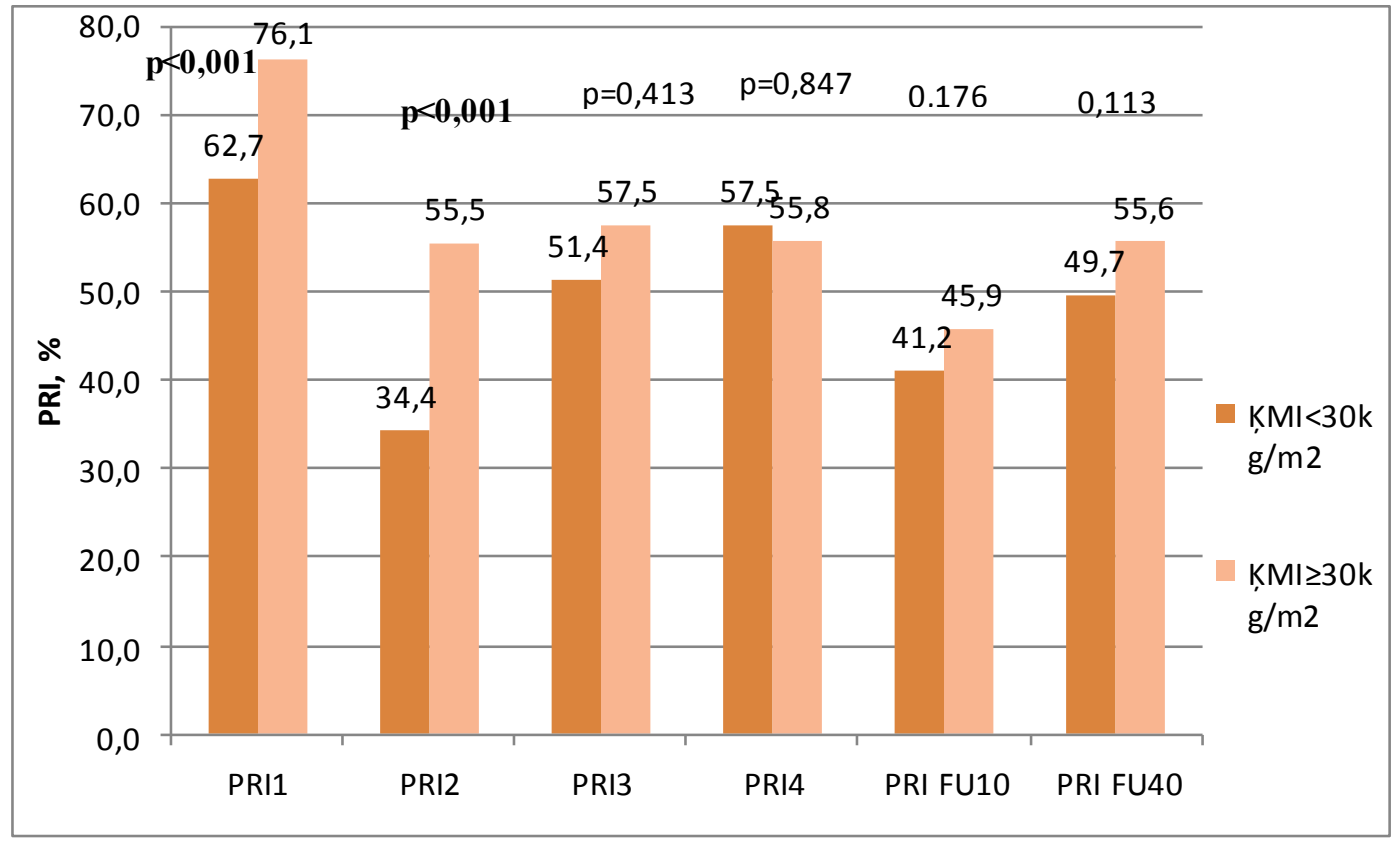

3.14. att. Adipozitātes ietekme uz klopidogrela devu stratēǵiju

Aprēķinos izmantots neatkarīgo izlašu t-tests, attēloti vidējie rezultāti (SD). PRI2, PRI3, PRI4 attiecīgi VASP PRI analīze pēc pirmās, otrās un trešās klopidogrela papildu PD saņemšanas. PRI FU10 - 10. dienas apsekošanas PRI analīze, PRI FU40 - 40. dienas apsekošanas PRI analīze. 


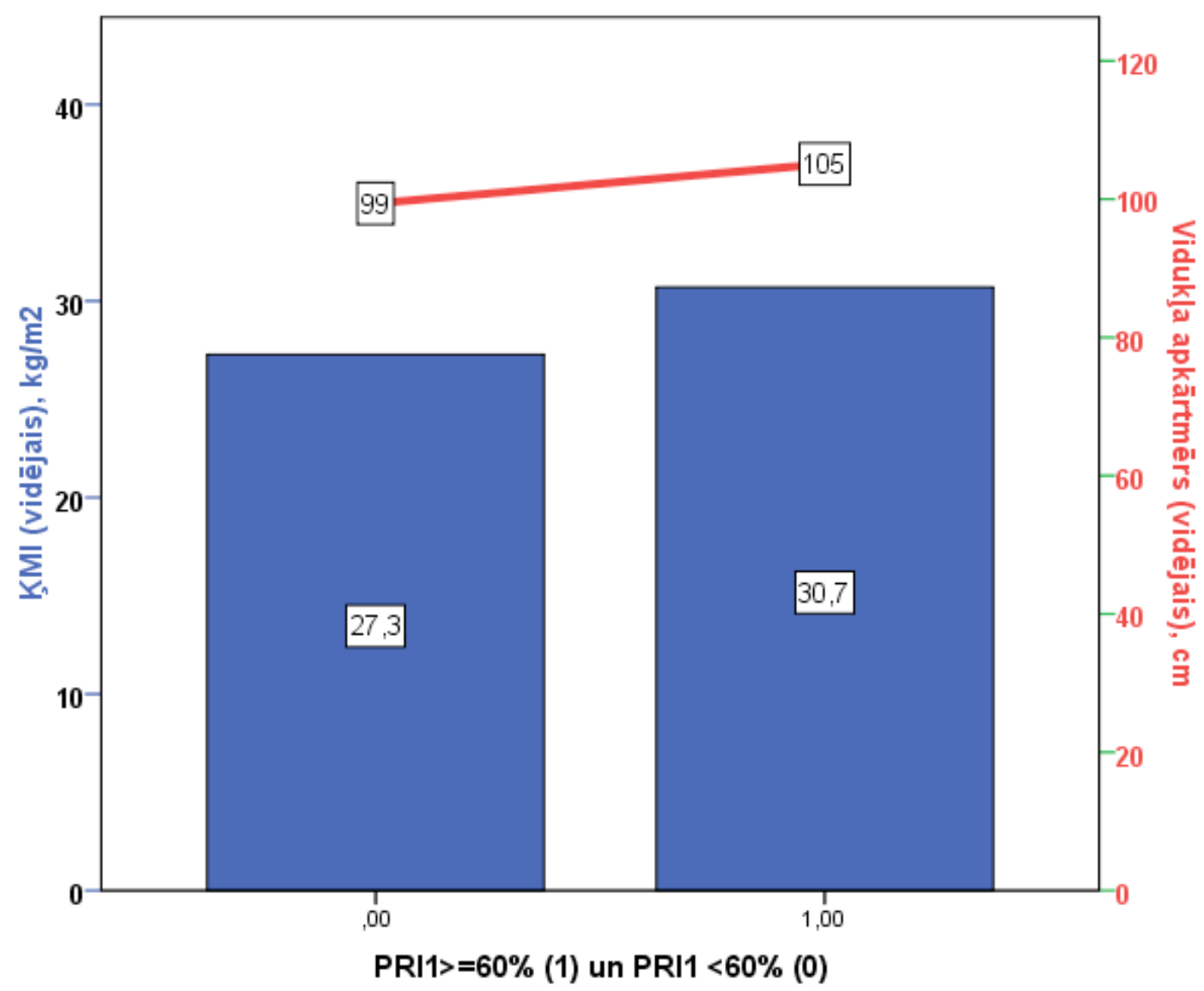

3.15.att. KMII un vidukḷa apkārtmēra ietekme uz klopidogrela efektivitāti pēe standarta PD saṇemšanas

\footnotetext{
ĶMI - ķermeṇa masas indekss, PRI1 - pirmās VASP PRI analīze pēc klopidogrela standarta PD saṇemšanas.
}

Analizējot ĶMI ietekmi uz PRI1 atkarībā no CYP2C19*2 genotipa, novēroja vidēji stipru statistiski ticamu pozitīvu korelāciju pacientiem ar neizmainītas funkcijas alēlēm (wt/wt) (r=403; p<0,001), kas liecina par augstākām PRI1 vērtībām pēc klopidogrela standarta PD saņemšanas pacientiem ar lielāku ĶMI (skat. 3.16. A attēlu). Savukārt pacientiem ar šī genotipa vismaz vienu samazinātas funkcijas alēli $(* 2 / * 2$ un *2/wt) statistiski ticamu korelāciju nenovēro $(\mathrm{r}=0,152 ; \mathrm{p}=0,499)$ (skat. 3.16. B attēlu). 
A

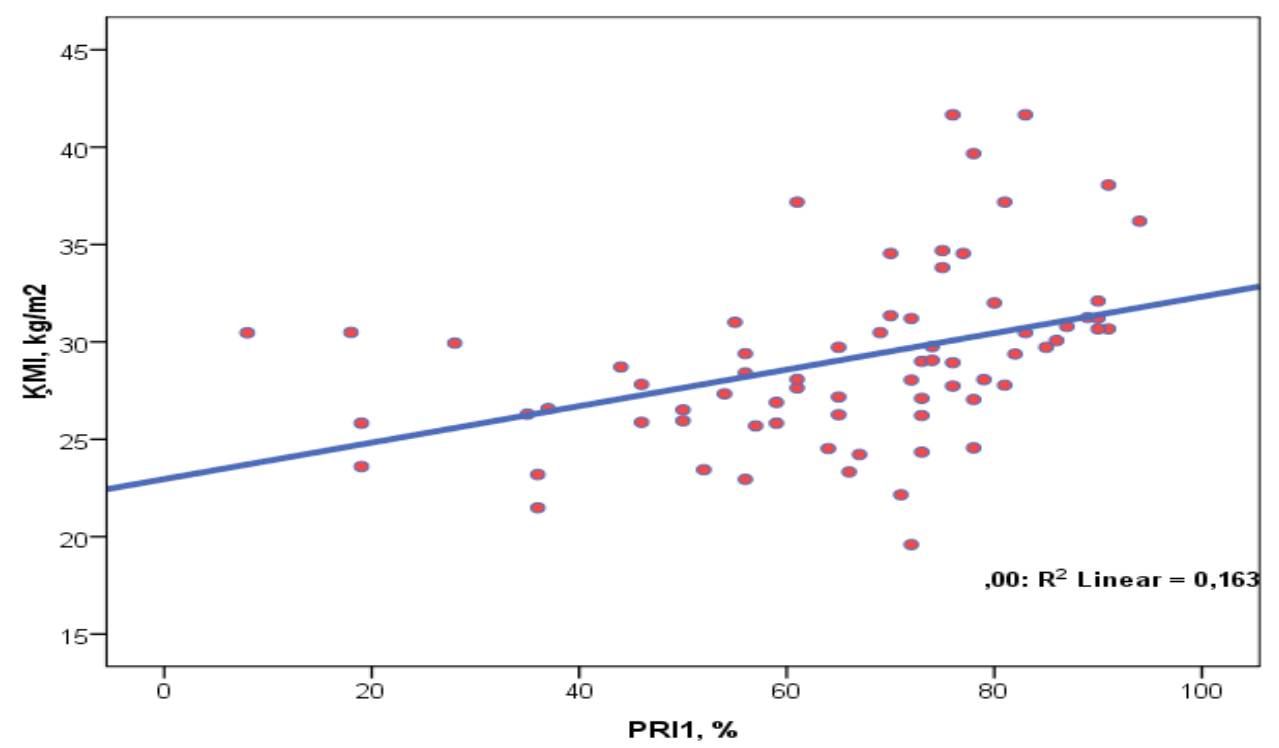

B

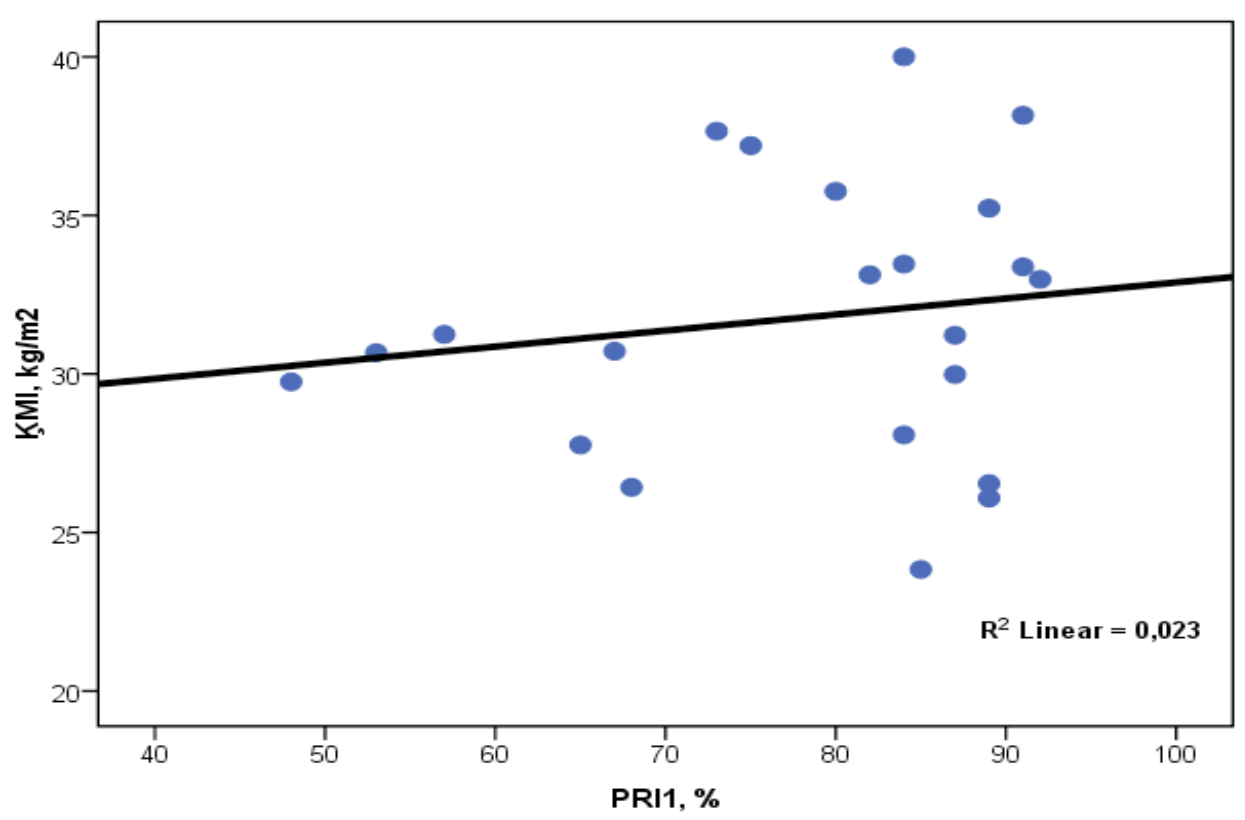

3.16. att. PRI1 atkarība no KMI pacientiem ar CYP2C19*2 genotipu: ar neizmainītas funkcijas alēlēm wt/wt (n=71) (A) un ar vismaz vienu samazinātas funkcijas alēli *2/*2 un wt $/ * 2(\mathrm{n}=22)(B)$

ĶMI - ķermen̦a masas indekss, PRI1 - pirmās VASP PRI analīze pēc klopidogrela standarta PD saņemšanas. 


\subsubsection{PSI ietekme uz klopidogrela papildu PD un augstāku UD efektivitāti}

Stacionārā PSI terapiju saṇēma $69(73,4 \%)$ pacienti, no kuriem $1(1,5 \%)$ pacients lietoja esomeprazolu, $11(15,9 \%)$ pacienti - omeprazolu un 57 (82,6\%) pacienti - pantoprazolu. Pēc pirmās klopidogrela papildu PD saņemšanas pacientu grupā ar hiporesponsivitāti vairāk bija PSI lietotāju, salīdzinot ar pacientiem, kuri nesaṇēma PSI terapiju, attiecīgi $16(69,6 \%)$ un $7(30,4 \%)(p=0,381)$ (skat. 3.25. tabulu). Šì tendence nesaglabājās pēc trešās klopidogrela papildu PD saņemšanas. Pie abām klopidogrela UD PSI lietotāju skaits bija procentuāli lielāks grupās ar PRI $\geq 60 \%$, attiecīgi 87,5\% un $76,5 \%$.

Pētījuma klopidogrela devu stratēgijas laikā novēroja palielinātas vidējās PRI vērtîbas pacientiem, kuri lietoja omeprazolu vai esomeprazolu, salīdzinot ar pacientu grupu ar pantoprazola terapiju (skat. 3.26.tabulu). Citi vienlaicīgi saṇemtie medikamenti būtiski neietekmēja PRI.

3.25. tabula

\section{Papildu klopidogrela PD un dažãdu UD efektivitātes atšķirības atkarībā no PSI} vienlaicīgas terapijas

\begin{tabular}{llll}
\hline PRI, \% & PSI (+), n(\%) & PSI (-), n(\%) & p \\
\hline PRI2 & & & \\
$<60 \%$ & $35(79,5)$ & $9(20,5)$ & 0,381 \\
$\geq 60 \%$ & $16(69,6)$ & $7(30,4)$ & \\
PRI3 & $10(83,3)$ & $2(16,7)$ & 0,193 \\
$<60 \%$ & $6(54,5)$ & $5(45,5)$ & \\
$\geq 60 \%$ & & $3(33,3)$ & 0,182 \\
PRI4 & $6(66,7)$ & $2(100,0)$ & \\
$<60 \%$ & - & $13(22,8)$ & 0,675 \\
$\geq 60 \%$ & $44(77,2)$ & $1(12,5)$ & \\
PRI FU10 & $7(87,5)$ & & 0,808 \\
$<60 \%$ & & $16(27,1)$ & \\
$\geq 60 \%$ & $43(72,9)$ & $8(23,5)$ & \\
PRI FU40 & $26(76,5)$ & & \\
$<60 \%$ & & & \\
$\geq 60 \%$ & & & \\
\hline
\end{tabular}

Aprēķinos izmantots Chi-square tests, attēlojot pscientu skaitu un \% konkrētā grupā. ĶMI ķermeņa masas indekss, PRI2, PRI3, PRI4 attiecīgi VASP PRI analīze pēc pirmās, otrās un trešās klopidogrela papildu PD saņemšanas. PRI FU10 - 10. dienas apsekošanas PRI analīze, PRI FU40 - 40. dienas apsekošanas PRI analīze. 
Vidējas PRI atšḳirības pacientiem pēc klopidogrela papildu PD un abu UD saṇemšanas atkarībā no saṇemtā PSI tipa

\begin{tabular}{llllll}
\hline $\begin{array}{l}\text { Vid. PRI, \% } \\
\text { (SD) }\end{array}$ & $\mathbf{n}$ & $\begin{array}{l}\text { Omeprazola un } \\
\text { esomeprazola lietotāju } \\
\text { grupa }\end{array}$ & $\mathbf{n}$ & $\begin{array}{l}\text { Pantoprazola } \\
\text { lietotāju } \\
\text { grupa }\end{array}$ & p \\
\hline PRI1 & 12 & $75,5(13,6)$ & 57 & $68,0(19,0)$ & 0,199 \\
PRI2 & 10 & $52,3(41,3)$ & 41 & $41,3(19,8)$ & 0,124 \\
PRI3 & 4 & $63,0(4,1)$ & 12 & $50,8(11,0)$ & 0,052 \\
PRI4 & 4 & $50,5(9,1)$ & 2 & $58,0(0,0)$ & 0,366 \\
PRI FU10 & 10 & $51,1(16,8)$ & 41 & $42,2(12,0)$ & 0,060 \\
PRI FU40 & 12 & $55,5(17,2)$ & 57 & $52,0(16,9)$ & 0,534 \\
\hline
\end{tabular}

Aprēķinos izmantots neatkarīgo izlašu t-tests, attēloti vidējie rezultāti (SD). PRI1 - VASP PRI pēc klopidogrela standarta PD saņemšanas, PRI2, PRI3, PRI4 attiecīgi VASP PRI analīze pēc pirmās, otrās un trešās klopidogrela papildu PD saņemšanas. PRI FU10 - 10. dienas apsekošanas PRI analīze, PRI FU40 - 40. dienas apsekošanas PRI analīze. 


\subsection{Pacientu ilgtermiṇa apsekošanas rezultāti}

Ilgtermiņa apsekošana tika veikta visiem 94 (100\%) pacientiem ar vidējo

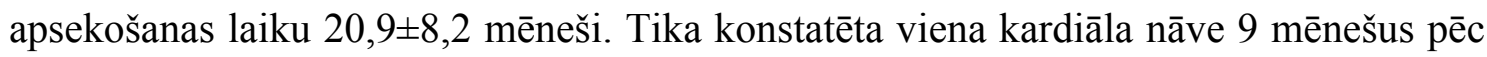
PCI pacientam, kas sākotnēji tika iedalīts grupā ar PRI $<60 \%$, ko var uzskatīt par iespējamu stenta trombozi $(1,1 \%)$.

Tika konstatēti $2(2,2 \%)$ MI, kas abi bija grupā ar klopidogrela hiporesponsivitāti. 1 (1,1\%) pacientam no šīs grupas tika veikta CABG, savukārt 22 (23,7\%) pacientiem tika veikta PCI, no kurām 2 bija mērksa asinsvada revaskularizācija (TVR), $1(1,1 \%)$ TLR, $21(22,8 \%)$ pacientam cita asinsvada PCI.

Kopējā apsekošanas laikā asiņošana tika konstatēta $5(5,4 \%)$ pacientiem, no kuriem $2(2,2 \%)$ bija nepieciešams veikt operāciju un asins elementu transfūziju. Savukārt pirmo 12 mēnešu laikā nozīmīga asiņošana bija $1(1,1 \%)$ pacientam no grupas ar PRI $1<60 \%$. 


\section{DISKUSIJA}

Darbā iegūtie rezultāti norāda uz CYP2C19*2 alēles nozīmīgu negatīvu ietekmi uz klopidogrela papildu PD un augstāku UD efektivitâti. Šīs alēles nēsātājiem PRI samazinās mazāk pēc pirmās klopidogrela papildu PD saņemšanas, kā arī augstāka UD ir retāk efektīva, salīdzinot ar pacientiem bez šì polimorfisma. Tendence uz mazāku PRI samazinājumu saglabājas arī turpmāko papildu PD stratēǵijas laikā, neiegūstot statistisko ticamību skaitliski mazo pacientu grupu dēḷ. Pēc mums pieejamās informācijas starptautiski citējamā literatūrā pašreiz nav atrodami pêtījumi, kuros vieniem un tiem pašiem pacientiem būtu analizēta iepriekš minēto genētisko polimorfismu ietekme gan uz papildu PD, gan uz dažādu UD efektivitāti. Tā kā lielākā daļa no pacientiem bija stacionēti plāna PCI ar DES veikšanai, līdz ar to mūsu pētijuma dati liecina par šo polimorfismu ietekmi arī uz standarta klopidogrela PD (300 mg) šo pacientu grupai atbilstoši vadlīnijām.

Darba rezultāti norāda, ka pacientiem ar vismaz vienu samazinātas funkcijas CYP2C19*2 alēli ir statistiski ticami augstāks PRI pēc klopidogrela standarta PD saņemšanas, salīdzinot ar pacientiem bez šì polimorfisma. Šĩ atrade sakrīt ar literatūras datiem [Bonello et al., 2010, Bonello et al., 2012], kur CYP2C19*2 heterozigotiem novēroja augstākas PRI vērtības pēc klopidogrela PD saņemšanas, salīdzinot ar pacientu grupu bez samazinātas funkcijas alēes. Savukārt pacientiem ar vismaz vienu CYP2C19*17 paaugstinātas funkcijas alēli mēs pētỉjumā novērojām tendenci uz labāku klopidogrela efektivitāti, ko apstiprina arī zinātniskā literatūra, kur šīs alēles nēsātājiem novēro zemākas PRI vērtîbas pēc klopidogrela PD saņemšanas [Sibbing et al., 2010].

Mūsu pētījumā nenovērojām citu CYP2C19 un CYP2C9 analizēto genotipu ietekmi uz PRI pēc klopidogrela standarta PD saņemšanas. Jāatzīmē, ka šiem genotipiem samazinātas funkcijas alēles bija reti sastopamas, kas var kavēt līdzīgas asociācijas atrades kā CYP2C19*2 gadījumā.

Pēc mūsu pētijuma rezultātiem vidējais PRI pēc pirrmās klopidogrela standarta piesātinošās devas bija statistiski ticami $(\mathrm{p}=0,005)$ augstāks CYP2C19*2 alēles nēsātājiem. Arī papildu PD stratēǵija CYP2C19*2 samazinātas funkcijas alēles nēsātājiem bija mazāk efektīva, attiecīgi novēroja mazāku PRI samazinājumu, lielāku nepieciešamo PD skaitu, salīdzinot ar pacientiem bez samazinātas funkcijas alēles. Tomēr lielākai daļai pacientu, neskatoties uz CYP2C19*2 samazinātas funkcijas alēles klātbūtni, izdevās sasniegt mūsu pētijuma PRI robežmērḳi. Arī CYP2C19*2 
homozigotam mūsu pētījumā šì devu stratēgeija izrādījās sekmīga. Jāpiebilst, ka pacientiem ar īstu rezistenci bija tikai viena $C Y P 2 C 19 * 2$ samazinātas funkcijas alēle, kas norāda uz iespējamu citu faktoru ietekmi hiporesponsivitātes predispozīcijai. Citu CYP2C19 un CYP2C9 genotipu gadījumā PD efekti bija līdzīgi polimorfismu grupās. CYP2C19*2 genotipa ietekme ir plaši pētīta un aprakstîta arī zinātniskajā literatūrā [Trenk et al., 2008, Simon et al., 2009, Wallentin et al., 2010], kur šo samazinātas funkcijas alēli saista ar palielinātu išēmisko notikumu un ST risku. Lai gan pētījumos VASP analīze biežāk tiek veikta pacientiem pirms PCI, saistot hiporesponsivitāti ar risku agrīno ST attīstībai [Gurbel et al., 2005, Blindt et al., 2007]. Arī Bonello et al. veiktajā pētījumā $88 \%$ pacientu ar vismaz vienu CYP2C19*2 samazinātas funkcijas alēli 3 klopidogrela papildu PD stratēǵija apliecināja efektivitāti, sasniedzot $\mathrm{PRI}<50 \%$ [Bonello et al., 2010]. Var secināt, ka gan CYP2C19*2 heterozigotiem, gan homozigotiem var sasniegt pietiekamu klopidogrela aktīvā metabolīta līmeni, izmantojot lielas klopidogrela devas. Tā kā bieži pētījumos šo pacientu ar abām CYP2C19*2 samazinātas funkcijas alēlēm skaits ir mazs, tādēl nepieciešama plašāka izpēte šai pacientu grupai.

Mūsu pētijuma rezultāti neapstiprina $A B C B 1$ C3435T genotipa ietekmi uz klopidogrela terapijas efektivitāti. Balstoties uz mūsu iegūtajiem datiem, varam runāt par tendenci uz augstākām PRI1 vērtībām pacientiem ar TT genotipu pēc klopidogrela standarta PD saņemšanas, lai gan netika sasniegta statistiski ticama atšķirīiba. Lai gan nesen publicētajā meta-analīzē $A B C B 1$ genotipa $\mathrm{T}$ alēle bija asociēta ar KV notikumu risku tiem pacientiem, kuri bija saņēmuši 300 mg klopidogrela $\mathrm{PD}$, pretēji pacientiem pēc 600 mg PD [Su et al., 2012], citu publikāciju rezultāti par š̄i genotipa lomu ir pretrunīgi. Piemēram, PLATO pētījumā ziņots par $A B C B 13435 \mathrm{CC}$ genotipa korelāciju ar paaugstinātu KV nāves, MI un CI notikumu attīstību [Wallentin et al., 2010], savukārt TRITON-TIMI 38 pētījuma rezultāti liecina par augstāku iepriekš minēto KV notikumu risku pacientiem ar pretēju (3535TT) ABCB1 genotipu [Mega et al., 2010].

Mūsu pētījumā iegūtie dati neapstiprināja $A B C B 1$ genotipa pārliecinošu ietekmi uz papildu PD stratēǵiju. Citā pētījumā šis genotips demostrēja statistiski ticamu asociāciju ar klopidogrela papildu PD stratēgijas neefktivitāti [Bonello et al., 2012]. Tā kā zinātnisko publikāciju dati par šī genotipa lomu uz PRI pēc klopidogrela standarta PD ir pretrun̄̄gi [Mega et al., 2010], tad nepieciešami papildu pêtījumi š̄is ietekmes precizēšanai atkarībā no pacientu etniskās piederības. 
Pēc pirmās VASP analīzes, kas tika veikta pēc klopidogrela standarta PD saņemšanas, neapmierinošu klopidogrela darbību mūsu pētījuma pacientu grupā novērojām lielākai daļai pacientu. Neskatoties uz palielinātu PRI robežvērtību, hiporesponsivitātes prevalence pacientu vidū pēc standarta PD saṇemšanas bija augstāka (72,3\%) nekā bija sagaidāms. Maz ticams, ka pacientu ar samazinātu reakciju uz klopidogrelu skaits Latvijā ir vidēji lielāks nekā līdzīgos iepriekš publicētos pētījumos [O'Donoghue et al., 2006, Angiolillo et al., 2007, Bonello et al., 2010], kur biežāk hiporesponsivitāti konstatē $50-60 \%$ gadījumu. Ja mēs pielietotu pētījumos biežāk izmantoto hiporesponsivitātes definīciju ar PRI $\geq 50 \%$, tad mūsu pētījumā būtu nedaudz vairāk pacientu ar samazinātu reakciju uz klopidogrelu - 86,2\%. Iespējams, ka augstāku PRI vērtību pētîjuma pacientu grupā varēja netieši provocēt klopidogrela 300 mg PD izmantošana, lai gan pacientiem pēc plāna PCI novēroja zemāku PRI nekā pēc 600 mg PD saņemšanas, kas ir indicēta AKS gadījumā. Iemesls šādiem pētījuma rezultātiem varētu būt tāds, ka AKS pacientiem vērojama augstāka trombocītu reaktivitāte trombocītu aktivācijas pamatslimības dēḷ. Šiem pacientiem mēdz būt arī citi nekoriḡēti riska faktori, kamēr pacientiem ar plāna PCI KSS diagnoze noteikta jau agrāk un jau tiek lietoti medikamenti sekundārai profilaksei. Iespējams, ka ticamāks skaidrojums PRI augstajām vērtībām varētu būt tas, ka iekḷaušanas kritērijs bija DES stentu izvēle, ko invazīvais kardiologs biežāk izvēlās pacientiem ar CD un sarežǵḡitākiem asinsvadu bojājumiem. Arī tas, ka veica VASP pēc PCI nevis pirms varētu paaugstināt PRI, lai gan tam pierādījumu nav.

Mūsu pētījumā stratēgija par papildu PD izmantošanu pacientiem ar hiporesponsivitāti būtu vērtējama kā diezgan sekmīga, respektīvi, lielākai daļai pacientu izdevās sasniegt PRI mērķi ar klopidogrela papildu PD, izņemot 2 pacientus, kuriem PRI saglabājās virs $60 \%$. Pielietotās papildu PD stratēǵijas pārliecinošā efektivitāte liecina par klopidogrela īstas rezistences samērā reto sastopamību, kas netieši norāda uz augstāka PRI mērķa izvēli pacientiem ar samazinātu reakciju uz klopidogrelu, lai atlasītu pacientu grupu ar augstāku ST un KV notikumu risku. Arī citu autoru dati apstiprina šo papildu PD pozitīvo efektu klopidogrela hiporesponsivitātes pārvarēšanai [Bonello et al., 2010, Bonello et al., 2009]. N̦emot vērā literatūrā minētos datus par plašu hiporesponsivitātes prevalences variabilitāti starp pacientiem ar mērķa PRI $<50 \%$ (16-50\%), ST pirmā gada laikā tomēr sastop salīdzinoši reti $(<1 \%)$ [Bonello et al., 2009, Mallouk et al., 2012, Sudhir et al., 2013], kas savukārt varētu liecināt par īstas klopidogrela rezistences kā viena no trombozi veicinošiem faktoriem reto izplatību. 
Jāatzīmēe, ka mūsu pētījuma 2 pacientiem ar īstu klopidogrela rezistenci antiagregantu terapijas nomaiņa uz jaunākas paaudzes medikamentu tikagreloru izrādījās pārliecinoši veiksmīga. Apsekojuma vizītē pēc 40 dienām PRI iegūtās skaitliskās vērtības samazinājumā novēroja strauju kritumu, attiecīgi par 57\%p un 65\%p. Tikagrelors kā jaunās paaudzes P2Y12 receptoru inhibitors arī citos pētījumos uzrāda lielāku trombocītu inhibīcijas pakāpi gan PD, gan UD lietošanas laikā, salīdzinot ar klopidogrelu [Wallentin et al., 2009, James et al., 2012]. Līidz ar to 1̄stas klopidogrela rezistences gadījumā tā ir laba medikamentozā alternatīva, ja nav kontrindicēts.

Mūsu pētījumā pirmo reizi Latvijā tika pielietota VASP analīze trombocītu reaktivitātes noteikšanai. Šo metodi izvēelējāmies, balstoties uz šī testa priekšrocībām, no kurām kā būtiskākās jāatzīmē tās, ka analīzi neietekmē citi vienlaicīgi saṇemtie medikamenti (piemēram, aspirīns, GP IIb/IIIa receptoru inhibitori) un ka analīzei nepieciešams mazs asiņu daudzums $(4 \mathrm{ml})$, ko var nepieciešamības gadījumā uzglabāt līdz analīzes veikšanai istabas temperatūrā līdz pat 48 stundām [Bonello et al., 2010]. Kā galvenais š̄is metodes trūkums jāatzīmē darbietilpīgs un laikietilpīgs parauga sagatavošanas un analīzes process.

Ņemot vērā to, ka vēl joprojām nav vienotas nostādnes par PRI robežvērtību VASP analīzes gadījumā, kas definētu samazinātu klopidogrela darbību un ietekmētu klīnisko iznākumu, palielinot KV notikumu risku, mūsu izvēlētais PRI mērķis bija $<60 \%$. Pārbaudot š̄ mērķa drošību un efektivitāti ilgtermiṇā, pirmā gada laikā stenta trombozi konstatēja $1(1,1 \%)$ pacientam no mūsu pētījuma grupas ar atbilstošu klopidogrela darbību - PRI1 bija 52\%. Iespējams, ka PRI mērķis $<50 \%$ šim pacientam būtu drošāks, lai gan 40 dienu apsekojuma vizītē šim pacientam PRI bija pat zem šis normas - 46\%. Biežāk citos zinātniskos pētījumos izmantotās PRI robežvērtības svārstās no 50 līdz 70\% [Blindt et al., 2007, Aradi et al., 2012, Bonello et al., 2012]. Jāatzīmēe, ka nav arī vienotas pieejas, kad un kuriem pacientiem pārbaudīt klopidogrela darbību, lai gan vairāku klīnisko pētījumu rezultāti liecina par VASP metodes saistību ar klīnisko iznākumu, īpaši pacientiem pēc PCI [Aleil et al., 2005, Angiolillo et al., 2007, Bonello et al., 2009]. Būtiski atzīmēt, ka stenta trombozi var veicināt arī ar klopidogrelu nesaistīti faktori, piemēram, PCI suboptimāls rezultāts ar nepietiekamu stenta apozīciju, kas šajā pētījumā netika analizēts, jo prasītu invazīvas attēldiagnostikas metodes pielietošanu visiem pacientiem.

Mūsu pētījumā novērojām augstākas PRI vērtības pacientiem ar CYP2C19*2 samazinātas funkcijas alēli abu UD lietošanas laikā. Jāatzīmēe, ka paaugstināta UD (150 
mg / dienā) šīs alēles nēsātājiem bija efektīvāka, salīdzinot ar standarta UD (75 mg / dienā). Citu mūsu pētījumā analizēto genotipu gadījumā statistiski ticamas klopidogrela UD efektivitātes atšķirības netika novērotas. Literatūrā sastop datus, ka CYP2C19*2 heterozigotiem trīskāršota UD (225 mg / dienā) sasniedz to pašu efektu kā klopidogrela standarta UD pacientiem bez samazinātas funkcijas alēles [Mega et al., 2011]. Šāda sakarība par augstākas klopidogrela UD efektivitāti $C Y P 2 C 19^{*} 2$ alēles nēsātājiem novērota arī citos iepriekš publicētos ziņojumos [Aleil et al., 2008, Price et al., 2011, Price et al., 2012], lai gan vēl joprojām nav datu par KV notikumu samazinājumu pēc šādas terapeitiskās stratēǵijas izmantošanas.

Mūsu pētījuma rezultāti atspoguļo ĶMI, kā arī vēdera apkārtmēra asociāciju ar PRI gan klopidogrela PD, gan UD statēgijas laikā, kura uzrāda statistisko ticamību pēc standarta un pirmās papildu PD. Ĺoti spilgti tas vērojams pacientiem ar adipozitāti (ĶMI $\geq 30 \mathrm{~kg} / \mathrm{m} 2)$. Citu kardiovaskulāro riska faktoru (CD, smēķēšana) gadījumā statistiskas atšķirības uz pētījuma terapijas stratēgiju nenovēro. Arī citos pētījumos tiek novērota ĶMI statistiski ticama asociācija ar PRI pēc klopidogrela PD, ko saista ar nepietiekamu klopidogrela devu šiem pacientiem [Bonello-Palot et al., 2009].

Ņemot vērā vienlaicīgi lietotos medikamentus klopidogrela terapijas laikā, mūsu pētījuma rezultāti norāda uz tendenci augstākām PRI vērtībām visā pētījuma devu stratēgijas laikā, vienlaicīgi lietojot omeprazolu vai esomeprazolu. Gan papildu klopidogrela PDs, gan augstāka UD bija mazāk efektīvas omeprazola un esomeprazola lietotāju grupā, salīdzinot ar pantoprazola lietotāju grupu. Š̄is PRI grupu atšķkirības nesasniedza statistisko ticamību mazā pacientu skaita dēḷ, kas bija lietojuši omeprazolu un esomeprazolu ambulatori. Arī stacionārā biežāk tika nozīmēta pantoprazola terapija. Citu vienlaicīgi saņemto zāḷu ietekme uz klopidogrela terapiju mūsu pētījumā netika novērota. Vēl joprojām veikto klīnisko pētījumu rezultāti par PSI un klopidogrela mijiedarbību ir pretrunīgi [Fernando et al., 2011, D'Ugo et al., 2013]. Nepieciešami prospektīvi, dubultakli, randomizēti, placebo kontrolēti pētījumi ar ilgtermiņa novērojumu un lielu pacientu skaitu. Lai gan par klopidogrela un PSI mijiedarbību nav pārliecinošu datu, tomēr ieteicams izvairīties no šo zāļu vienlaicīgas lietošanas. PSI rekomendēts nozīmēt tikai pacientiem ar augstu kuņǵa - zarnu trakta asiņošanas risku atsevišķos gadījumos, piemēram, anamnēzē asiņošana no kuņğa - zarnu trakta, vecums, vienlaicīga varfarīna, NPL terapija. Šādos gadījumos rekomendē izvairīties no omeprazola un esomeprazola lietošanas, kas ir PSI ar pastiprinātu afinitāti uz CYP2C19 enzīmu. 
Kā galvenās atšķirības no citiem līdzīgiem pētījumiem, piemēram, Bonello et al. pētījuma [Bonello et al., 2012] var atzīmēt to, ka pacientu skaits mūsu pētījumā bija mazāks, lielākā daḷa no pacientiem bija stacionēti plāna PCI veikšanai, saņemot klopidogrela 300 mg PD atbilstoši vadlīnijām [Wijns et al., 2010], arī PRI mērķis bija augstāks. Jāpiebilst, ka PRI noteikšana pacientiem tika veikta pēc PCI.

Kā mūsu pētījuma priekšrocību var minēt to, ka PRI noteikšanai izmantojām tieši VASP metodi, kuras rezultātu nevar ietekmēt aspirīna un GP IIb/IIIa inhibitoru vienlaicīga lietošana, atšksirībā no tādām bieži lietotām metodēm kā Verify Now tests un PlateletWorks. Pie galveniem pētījuma trūkumiem var minēt relatīvi mazo pacientu skaitu, neviendabīgu pacientu grupu (iekḷauti gan plāna, gan akūtie pacienti).

\section{PRAKTISKAIS PIELIETOJUMS}

Mūsu pētîjuma rezultāti var veicināt sekmīgas terapeitiskās stratēgijas izvēli pacientiem ar samazinātu atbildes reakciju uz klopidogrela terapiju. Vienlaicīga trombocītu reaktivitātes un $C Y P 2 C 19 * 2$ alēles klātbūtnes noteikšana var būt pārāka nekā tikai trombocītu funkcionālo testu izmantošana atsevišķi, lai sasniegtu optimālu P2Y12 inhibīcijas pakāpi katram pacientam.

Pēc mūsu pētījuma datiem CYP2C19*2 samazinātas funkcijas alēles noteikšana ļautu prognozēt, ka standarta PD un UD būs mazāk efektīvas, īpaši pacientiem ar citiem hiporesponsivitāti provocējošiem faktoriem - palielinātu ĶMI, kā arī vienlaicīgu PSI, īpaši omeprazola vai esomeprazola terapiju. 


\section{SECINĀJUMI}

1. Pacientiem ar vismaz vienu CYP2C19*2 samazinātas funkcijas alēli klopidogrela standarta piesātinošās devas spēja nomākt trombocītu reaktivitāti ir zemāka. Hiporesponsivitātes gadījumā CYP2C19*2 alēles klātbūtne ir asociēta ar papildu PD samazinātu efektivitāti.

2. Gandrīz divām trešdaḷām pacientu ar klopidogrela hiporesponsivitāti jau pēc pirmās papildu PD izdodas sasniegt mērksa $\mathrm{PRI}<60 \%$, kas liecina par klopidogrela papildu PD efektivitāti vairumā gadījumu.

3. İstu klopidogrela rezistenci novēro reti - 2,1\% pacientu, kam nav iespējams sasniegt PRI $<60 \%$ pat ar trīs papildu PD. Klopidogrela rezistences gadījumā tikagrelors ir pārliecinoši efektīvs.

4. Pacientiem, kas ir CYP2C19*2 alēles nēsātāji, ar standarta UD (75 mg) trīs ceturtdaḷās gadījumu netiek novērota atbilstoša trombocītu inhibīcija. Augstāka $150 \mathrm{mg}$ klopidogrela UD šiem pacientiem ir efektīvāka, bet joprojām nav pietiekama $29 \%$ gadījumu.

5. Adipozitāte ir svarīgs fenotipisks faktors, kas pasliktina gan papildu PD, gan augstāku UD efektivitāti pacientiem ar klopidogrela hiporesponsivitāti.

6. Protonu sūkṇu inhibitoru lietotājiem ir tendence uz samazinātu klopidogrela efektivitāti gan pēc papildu PD, gan abu UD lietošanas laikā. Omeprazola un esomeprazola lietotājiem klopidogrela efektivitāte ir zemāka visā klopidogrela devu stratēǵijas laikā, salīdzinot ar pantoprazola lietotājiem.

7. Viena gada laikā tika konstatēta tikai viena iespējama stenta tromboze, kas liek domāt par piesātinošo devu stratẹgijas relatīvu drošību ilgtermiṇā atbilstoši PRI mērķim $<60 \%$. Tomēr PRI mērķi $<60 \%$ nepieciešams apstiprināt lielākos prospektīvos pētījumos. 


\section{IZMANTOTĀ LITERATŪRA}

1. Aksu K., Donmez A., Keser G. Inflammation-induced thrombosis: mechanisms, disease associations and management // Curr Pharm Des, 2012; 18 (11): 1478-1493.

2. Aleil B., Jacquemin L., De Poli F., et al. Clopidogrel $150 \mathrm{mg} /$ day to overcome low responsiveness in patients undergoing elective percutaneous coronary intervention: results from the VASP-02 (Vasodilator-Stimulated Phosphoprotein-02) randomized study // JACC Cardiovasc Interv, 2008; 1 (6): 631-638.

3. Aleil B., Ravanat C., Cazenave J. P., et al. Flow cytometric analysis of intraplatelet VASP phosphorylation for the detection of clopidogrel resistance in patients with ischemic cardiovascular diseases // J Thromb Haemost, 2005; 3 (1): 85-92.

4. Alstrom U., Granath F., Oldgren J., et al. Platelet inhibition assessed with VerifyNow, flow cytometry and PlateletMapping in patients undergoing heart surgery // Thromb Res, 2009; 124 (5): 572-577.

5. Ancrenaz V., Daali Y., Fontana P., et al. Impact of genetic polymorphisms and drugdrug interactions on clopidogrel and prasugrel response variability // Curr Drug Metab, 2010; 11 (8): 667-677.

6. Andersson C., Lyngbaek S., Nguyen C. D., et al. Association of clopidogrel treatment with risk of mortality and cardiovascular events following myocardial infarction in patients with and without diabetes // Jama, 2012; 308 (9): 882-889.

7. Ang L., Palakodeti V., Khalid A., et al. Elevated plasma fibrinogen and diabetes mellitus are associated with lower inhibition of platelet reactivity with clopidogrel // J Am Coll Cardiol, 2008; 52 (13): 1052-1059.

8. Angiolillo D. J., Fernandez-Orliz A., Bernardo E., et al. Variability in Individual Responsiveness to Clopidogrel. Clinical Implications, Management, and Future Perspectives. // JACC, 2007; 49 (14): 1505-1516. 
9. Angiolillo D. J., Fernandez-Ortiz A., Bernardo E., et al. Variability in individual responsiveness to clopidogrel: clinical implications, management, and future perspectives // J Am Coll Cardiol, 2007; 49 (14): 1505-1516.

10. Angiolillo D. J., Fernandez-Ortiz A., Bernardo E., et al. 807 C/T Polymorphism of the glycoprotein Ia gene and pharmacogenetic modulation of platelet response to dual antiplatelet treatment // Blood Coagul Fibrinolysis, 2004; 15 (5): 427-433.

11. Angiolillo D. J., Gibson C. M., Cheng S., et al. Differential effects of omeprazole and pantoprazole on the pharmacodynamics and pharmacokinetics of clopidogrel in healthy subjects: randomized, placebo-controlled, crossover comparison studies // Clin Pharmacol Ther, 2011; 89 (1): 65-74.

12.Angiolillo D. J., Shoemaker S. B., Desai B., et al. Randomized comparison of a high clopidogrel maintenance dose in patients with diabetes mellitus and coronary artery disease: results of the Optimizing Antiplatelet Therapy in Diabetes Mellitus (OPTIMUS) study // Circulation, 2007; 115 (6): 708-716.

13. Aradi D., Komocsi A., Vorobcsuk A., et al. Prognostic significance of high onclopidogrel platelet reactivity after percutaneous coronary intervention: systematic review and meta-analysis // Am Heart J, 2010; 160 (3): 543-551.

14. Aradi D., Rideg O., Vorobcsuk A., et al. Justification of $150 \mathrm{mg}$ clopidogrel in patients with high on-clopidogrel platelet reactivity // Eur J Clin Invest, 2012; 42 (4): 384-392.

15. Balasubramaniam K., Viswanathan G. N., Marshall S. M., Zaman A. G. Increased atherothrombotic burden in patients with diabetes mellitus and acute coronary syndrome: a review of antiplatelet therapy // Cardiol Res Pract, 2012; 2012 (909154): 909154.

16. Barone-Rochette G., Ormezzano O., Polack B., et al. Resistance to platelet antiaggregants: an important cause of very late thrombosis of drug eluting stents? Observations from five cases // Arch Cardiovasc Dis, 2008; 101 (2): 100-107. 
17. Bates E. R., Lau W. C. , Angiolillo D. J. Clopidogrel-drug interactions // J Am Coll Cardiol, 2011; 57 (11): 1251-1263.

18. Beitelshees A. L., Horenstein R. B., Vesely M. R., et al. Pharmacogenetics and clopidogrel response in patients undergoing percutaneous coronary interventions // Clin Pharmacol Ther, 2011; 89 (3): 455-459.

19. Bliden K. P., Dichiara J., Lawal L., et al. The association of cigarette smoking with enhanced platelet inhibition by clopidogrel // J Am Coll Cardiol, 2008; 52 (7): 531-533.

20. Blindt R., Stellbrink K., De Taeye A., et al. The significance of vasodilatorstimulated phosphoprotein for risk stratification of stent thrombosis // Thromb Haemost, 2007; 98 (6): 1329-1334.

21. Blume H., Donath F., Warnke A., Schug B. S. Pharmacokinetic drug interaction profiles of proton pump inhibitors // Drug Saf, 2006; 29 (9): 769-784.

22. Bonello-Palot N., Armero S., Paganelli F., et al. Relation of body mass index to high on-treatment platelet reactivity and of failed clopidogrel dose adjustment according to platelet reactivity monitoring in patients undergoing percutaneous coronary intervention // Am J Cardiol, 2009; 104 (11): 1511-1515.

23. Bonello L., Armero S., Ait Mokhtar O., et al. Clopidogrel loading dose adjustment according to platelet reactivity monitoring in patients carrying the $2 \mathrm{C} 19 * 2$ loss of function polymorphism // J Am Coll Cardiol, 2010; 56 (20): 1630-1636.

24. Bonello L., Bonello-Palot N., Armero S., et al. Impact of P2Y12-ADP receptor polymorphism on the efficacy of clopidogrel dose-adjustment according to platelet reactivity monitoring in coronary artery disease patients // Thromb Res, 2009; 1313.

25. Bonello L., Camoin-Jau L., Armero S., et al. Tailored clopidogrel loading dose according to platelet reactivity monitoring to prevent acute and subacute stent thrombosis // Am J Cardiol, 2009; 103 (1): 5-10.

26. Bonello L., Camoin-Jau L., Arques S., et al. Adjusted clopidogrel loading doses according to vasodilator-stimulated phosphoprotein phosphorylation index decrease rate of major adverse cardiovascular events in patients with clopidogrel resistance: a 
multicenter randomized prospective study // J Am Coll Cardiol, 2008; 51 (14): 14041411.

27. Bonello L., Camoin-Jau L., Mancini J., et al. Factors associated with the failure of clopidogrel dose-adjustment according to platelet reactivity monitoring to optimize P2Y12-ADP receptor blockade // Thromb Res, 2012; 130 (1): 70-74.

28. Bonello L., Tantry U. S., Marcucci R., et al. Consensus and future directions on the definition of high on-treatment platelet reactivity to adenosine diphosphate // J Am Coll Cardiol, 2010; 56 (12): 919-933.

29. Bouman H., Parlak E., Van Werkum J., et al. Which platelet function test is suitable to monitor clopidogrel responsiveness? A pharmacokinetic analysis on the active metabolite of clopidogrel // J Thromb Haemost, 2009; 2121.

30. Brandt J. T., Close S. L., Iturria S. J., et al. Common polymorphisms of CYP2C19 and CYP2C9 affect the pharmacokinetic and pharmacodynamic response to clopidogrel but not prasugrel // J Thromb Haemost, 2007; 5 (12): 2429-2436.

31. Brar S. S., Ten Berg J., Marcucci R., et al. Impact of platelet reactivity on clinical outcomes after percutaneous coronary intervention. A collaborative meta-analysis of individual participant data // J Am Coll Cardiol, 2011; 58 (19): 1945-1954.

32. Braun O., Angiolillo D. J., Ferreiro J. L., et al. Enhanced active metabolite generation and platelet inhibitionwith prasugrel compared to clopidogrel regardless of genotype in thienopyridine metabolic pathways // Thromb Haemost, 2013; 110 (20130905): 20130905.

33. Braunwald E., Angiolillo D., Bates E., et al. Assessing the current role of platelet function testing // Clin Cardiol, 2008; 31 (3 Suppl 1): I10-16.

34. Breet N. J., Van Werkum J. W., Bouman H. J., et al. Comparison of platelet function tests in predicting clinical outcome in patients undergoing coronary stent implantation // Jama, 2010; 303 (8): 754-762.

35. Cattaneo M. Light transmission aggregometry and ATP release for the diagnostic assessment of platelet function // Semin Thromb Hemost, 2009; 35 (2): 158-167. 
36. Cavallari L. H., Jeong H. , Bress A. Role of cytochrome P450 genotype in the steps toward personalized drug therapy // Pharmgenomics Pers Med, 2011; 4 123-136.

37. Cayla G., Macia J. C., Rabesandratana H., et al. Flow cytometric assessment of vasodilator-stimulated phosphoprotein: prognostic value of recurrent cardiovascular events after acute coronary syndromes // Arch Cardiovasc Dis, 2008; 101 (11-12): 743751.

38. Celik T., Iyisoy A., Gul H. , Isik E. Clopidogrel resistance: a diagnostic challenge // Int J Cardiol, 2009; 131 (2): 267-268; author reply 268-269.

39. Chang Y. W., Liao C. H., Day Y. J. Platelet function analyzer (PFA-100) offers higher sensitivity and specificity than thromboelastography (TEG) in detection of platelet dysfunction // Acta Anaesthesiol Taiwan, 2009; 47 (3): 110-117.

40. Cialdella P., Gustapane M., Camaioni C., Biasucci L. M. What's new about clopidogrel // Minerva Cardioangiol, 2013; 61 (6): 683-689.

41. Cuisset T., Frere C., Quilici J., et al. Glycoprotein IIb/IIIa inhibitors improve outcome after coronary stenting in clopidogrel nonresponders: a prospective, randomized study // JACC Cardiovasc Interv, 2008; 1 (6): 649-653.

42. Cuisset T., Frere C., Quilici J., et al. Comparison of omeprazole and pantoprazole influence on a high 150-mg clopidogrel maintenance dose the PACA (Proton Pump Inhibitors And Clopidogrel Association) prospective randomized study // J Am Coll Cardiol, 2009; 54 (13): 1149-1153.

43. Cuisset T., Quilici J., Cohen W., et al. Usefulness of high clopidogrel maintenance dose according to $\mathrm{CYP} 2 \mathrm{C} 19$ genotypes in clopidogrel low responders undergoing coronary stenting for non ST elevation acute coronary syndrome // Am J Cardiol, 2011; 108 (6): 760-765.

44. D'ugo E., Rossi S., De Caterina R. Proton pump inhibitors and clopidogrel: an association to avoid? // Intern Emerg Med, 2013; P. 13.

45. Damman P., Woudstra P., Kuijt W. J., et al. P2Y12 platelet inhibition in clinical practice // J Thromb Thrombolysis, 2012; 33 (2): 143-153. 
46. Dansette P. M., Rosi J., Bertho G., Mansuy D. Cytochromes P450 catalyze both steps of the major pathway of clopidogrel bioactivation, whereas paraoxonase catalyzes the formation of a minor thiol metabolite isomer // Chem Res Toxicol, 2012; 25 (2): $348-356$.

47. El Ghannudi S., Ohlmann P., Jesel L., et al. Impaired inhibition of P2Y(12) by clopidogrel is a major determinant of cardiac death in diabetes mellitus patients treated by percutaneous coronary intervention // Atherosclerosis, 2011; 217 (2): 465-472.

48. Farid N. A., Kurihara A., Wrighton S. A. Metabolism and disposition of the thienopyridine antiplatelet drugs ticlopidine, clopidogrel, and prasugrel in humans // J Clin Pharmacol, 2010; 50 (2): 126-142.

49. Feher G., Koltai K., Alkonyi B., et al. Clopidogrel resistance: role of body mass and concomitant medications // Int J Cardiol, 2007; 120 (2): 188-192.

50. Fernando H., Dart A. M., Peter K., Shaw J. A. Proton pump inhibitors, genetic polymorphisms and response to clopidogrel therapy // Thromb Haemost, 2011; 105 (6): 933-944.

51. Ferreiro J. L., Gomez-Hospital J. A., Angiolillo D. J. Platelet abnormalities in diabetes mellitus // Diab Vasc Dis Res, 2010; 7 (4): 251-259.

52. Ferreiro J. L., Ueno M., Capodanno D., et al. Pharmacodynamic effects of concomitant versus staggered clopidogrel and omeprazole intake: results of a prospective randomized crossover study // Circ Cardiovasc Interv, 2010; 3 (5): 436441.

53. Floyd C. N., Ferro A. The P1A1/A2 Polymorphism of Glycoprotein IIIa in Relation to Efficacy of Antiplatelet Drugs: a Systematic Review and Meta-analysis // Br J Clin Pharmacol, 2013; 2013 (9): 12204.

54. Gaglia M. A., Jr.,Torguson R., Pakala R., et al. Relation of body mass index to ontreatment (clopidogrel + aspirin) platelet reactivity // Am J Cardiol, 2011; 108 (6): 766771. 
55. Galic E., Vrbanic L., Kapitanovic S., et al. P2RY12 gene polymorphisms and effect of clopidogrel on platelet aggregation // Coll Antropol, 2013; 37 (2): 491-498.

56. Galla J. M., Nicholls S. J. Pharmacologic therapy for coronary atherosclerosis in patients with Type 2 diabetes mellitus // Expert Rev Cardiovasc Ther, 2009; 7 (1): $85-93$.

57. Gilard M., Arnaud B., Cornily J. C., et al. Influence of omeprazole on the antiplatelet action of clopidogrel associated with aspirin: the randomized, double-blind OCLA (Omeprazole CLopidogrel Aspirin) study // J Am Coll Cardiol, 2008; 51 (3): 256-260.

58. Giusti B., Gori A. M., Marcucci R., et al. Relation of cytochrome P450 2C19 lossof-function polymorphism to occurrence of drug-eluting coronary stent thrombosis // Am J Cardiol, 2009; 103 (6): 806-811.

59. Gladding P., Webster M., Zeng I., et al. The antiplatelet effect of higher loading and maintenance dose regimens of clopidogrel: the PRINC (Plavix Response in Coronary Intervention) trial // JACC Cardiovasc Interv, 2008; 1 (6): 612-619.

60. Good C. W., Steinhubl S. R., Brennan D. M., et al. Is there a clinically significant interaction between calcium channel antagonists and clopidogrel?: results from the Clopidogrel for the Reduction of Events During Observation (CREDO) trial // Circ Cardiovasc Interv, 2012; 5 (1): 77-81.

61. Goodman S. G., Clare R., Pieper K. S., et al. Association of proton pump inhibitor use on cardiovascular outcomes with clopidogrel and ticagrelor: insights from the platelet inhibition and patient outcomes trial // Circulation, 2012; 125 (8): 978-986.

62. Goswami S., Cheng-Lai A., Nawarskas J. Clopidogrel and genetic testing: is it necessary for everyone? // Cardiol Rev, 2012; 20 (2): 96-100.

63. Gremmel T., Steiner S., Seidinger D., et al. Smoking promotes clopidogrel-mediated platelet inhibition in patients receiving dual antiplatelet therapy // Thromb Res, 2009; 124 (5): 588-591. 
64. Gremmel T., Steiner S., Seidinger D., et al. Calcium-channel blockers decrease clopidogrel-mediated platelet inhibition // Heart, 2010; 96 (3): 186-189.

65. Gurbel P. A., Bliden K. P., Hayes K. M., et al. The relation of dosing to clopidogrel responsiveness and the incidence of high post-treatment platelet aggregation in patients undergoing coronary stenting // J Am Coll Cardiol, 2005; 45 (9): 1392-1396.

66. Gurbel P. A., Bliden K. P., Hiatt B. L., O'connor C. M. Clopidogrel for coronary stenting: response variability, drug resistance, and the effect of pretreatment platelet reactivity // Circulation, 2003; 107 (23): 2908-2913.

67. Gurbel P. A., Bliden K. P., Zaman K. A., et al. Clopidogrel loading with eptifibatide to arrest the reactivity of platelets: results of the Clopidogrel Loading With Eptifibatide to Arrest the Reactivity of Platelets (CLEAR PLATELETS) study // Circulation, 2005; 111 (9): 1153-1159.

68. Gurbel P. A., Tantry U. S. Clopidogrel resistance? // Thromb Res, 2007; 120 (3): $311-321$.

69. Hall H. M., Banerjee S., Mcguire D. K. Variability of clopidogrel response in patients with type 2 diabetes mellitus // Diab Vasc Dis Res, 2011; 8 (4): 245-253.

70. Harmsze A. M., Robijns K., Van Werkum J. W., et al. The use of amlodipine, but not of P-glycoprotein inhibiting calcium channel blockers is associated with clopidogrel poor-response // Thromb Haemost, 2010; 103 (5): 920-925.

71. Harmsze A. M., Van Werkum J. W., Souverein P. C., et al. Combined influence of proton-pump inhibitors, calcium-channel blockers and CYP2C19*2 on on-treatment platelet reactivity and on the occurrence of atherothrombotic events after percutaneous coronary intervention // J Thromb Haemost, 2011; 9 (10): 1892-1901.

72. Hayward C. P., Harrison P., Cattaneo M., et al. Platelet function analyzer (PFA)-100 closure time in the evaluation of platelet disorders and platelet function // $\mathrm{J}$ Thromb Haemost, 2006; 4 (2): 312-319. 
73. Hazarbasanov D., Velchev V., Finkov B., et al. Tailoring clopidogrel dose according to multiple electrode aggregometry decreases the rate of ischemic complications after percutaneous coronary intervention // J Thromb Thrombolysis, 2012; 34 (1): 85-90.

74. Hochholzer W., Trenk D., Fromm M. F., et al. Impact of cytochrome P450 2C19 loss-of-function polymorphism and of major demographic characteristics on residual platelet function after loading and maintenance treatment with clopidogrel in patients undergoing elective coronary stent placement // J Am Coll Cardiol, 2010; 55 (22): $2427-2434$.

75. Hochtl T., Tentzeris I., Schror K., Huber K. Antiplatelet function variability in clopidogrel-treated patients: need for new antiplatelet agents // Fundam Clin Pharmacol, 2012; $26(1): 2-10$.

76. Holmes D. R., Dehmer G. J., Kaul S., et al. ACCF/AHA Clopidogrel clinical alert: approaches to the FDA "boxed warning": a report of the American College of Cardiology Foundation Task Force on Clinical Expert Consensus Documents and the American Heart Association // Circulation, 2010; 122 (5): 537-557.

77. Hulot J. S., Collet J. P., Silvain J., et al. Cardiovascular risk in clopidogrel-treated patients according to cytochrome $\mathrm{P} 4502 \mathrm{C} 19 * 2$ loss-of-function allele or proton pump inhibitor coadministration: a systematic meta-analysis // J Am Coll Cardiol, 2010; $56(2): 134-143$.

78. Ivandic B., Frey N. New approaches and indications for the analysis of platelet function in cardiology // Hamostaseologie, 2011; 31 (2): 73-76.

79. James S. K., Storey R. F., Khurmi N. S., et al. Ticagrelor versus clopidogrel in patients with acute coronary syndromes and a history of stroke or transient ischemic attack // Circulation, 2012; 125 (23): 2914-2921.

80. Kalyanasundaram A., Lincoff A. M. Managing adverse effects and drug-drug interactions of antiplatelet agents // Nat Rev Cardiol, 2011; 8 (10): 592-600. 
81. Kazui M., Nishiya Y., Ishizuka T., et al. Identification of the human cytochrome P450 enzymes involved in the two oxidative steps in the bioactivation of clopidogrel to its pharmacologically active metabolite // Drug Metab Dispos, 2010; 38 (1): 92-99.

82. Kim H., Lee H. K., Han K., Jeon H. K. Prevalence and risk factors for aspirin and clopidogrel resistance in patients with coronary artery disease or ischemic cerebrovascular disease // Ann Clin Lab Sci, 2009; 39 (3): 289-294.

83. King S. B., 3rd, Smith S. C., Jr.,Hirshfeld J. W., Jr., et al. 2007 Focused Update of the ACC/AHA/SCAI 2005 Guideline Update for Percutaneous Coronary Intervention: a report of the American College of Cardiology/American Heart Association Task Force on Practice Guidelines: 2007 Writing Group to Review New Evidence and Update the ACC/AHA/SCAI 2005 Guideline Update for Percutaneous Coronary Intervention, Writing on Behalf of the 2005 Writing Committee // Circulation, 2008; 117 (2): 261-295.

84. Kirchheiner J., Brockmoller J. Clinical consequences of cytochrome P450 2C9 polymorphisms // Clin Pharmacol Ther, 2005; 77 (1): 1-16.

85. Kuliczkowski W., Witkowski A., Polonski L., et al. Interindividual variability in the response to oral antiplatelet drugs: a position paper of the Working Group on antiplatelet drugs resistance appointed by the Section of Cardiovascular Interventions of the Polish Cardiac Society, endorsed by the Working Group on Thrombosis of the European Society of Cardiology // Eur Heart J, 2009; 30 (4): 426-435.

86. Kwok C. S., Loke Y. K. Effects of proton pump inhibitors on platelet function in patients receiving clopidogrel: a systematic review // Drug Saf, 2012; 35 (2): 127-139.

87. Lau W. C., Waskell L. A., Watkins P. B., et al. Atorvastatin reduces the ability of clopidogrel to inhibit platelet aggregation: a new drug-drug interaction // Circulation, 2003; 107 (1): 32-37.

88. Leoncini M., Toso A., Maioli M., et al. High-dose atorvastatin on the pharmacodynamic effects of double-dose clopidogrel in patients undergoing percutaneous coronary interventions: The ACHIDO (Atorvastatin and Clopidogrel HIgh DOse in stable patients with residual high platelet activity) study // JACC Cardiovasc Interv, 2013; 6 (2): 169-179. 
89. Leoncini M., Toso A., Maioli M., Bellandi F. Statin and clopidogrel pharmacological interaction // G Ital Cardiol (Rome), 2013; 14 (9): 574-584.

90. Lev E. I., Patel R. T., Maresh K. J., et al. Aspirin and clopidogrel drug response in patients undergoing percutaneous coronary intervention: the role of dual drug resistance // J Am Coll Cardiol, 2006; 47 (1): 27-33.

91. Lewis L. D. Drug-drug interactions: is there an optimal way to study them? // $\mathrm{Br} \mathrm{J}$ Clin Pharmacol, 2010; 70 (6): 781-783.

92. Mallouk N., Labruyere C., Reny J. L., et al. Prevalence of poor biological response to clopidogrel: a systematic review // Thromb Haemost, 2012; 107 (3): 494-506.

93. Malmstrom R. E., Ostergren J., Jorgensen L., Hjemdahl P. Influence of statin treatment on platelet inhibition by clopidogrel - a randomized comparison of rosuvastatin, atorvastatin and simvastatin co-treatment // J Intern Med, 2009; 266 (5): 457-466.

94. Mega J. L., Close S. L., Wiviott S. D., et al. Cytochrome p-450 polymorphisms and response to clopidogrel // N Engl J Med, 2009; 360 (4): 354-362.

95. Mega J. L., Close S. L., Wiviott S. D., et al. Genetic variants in ABCB1 and CYP2C19 and cardiovascular outcomes after treatment with clopidogrel and prasugrel in the TRITON-TIMI 38 trial: a pharmacogenetic analysis // Lancet, 2010; 376 (9749): $1312-1319$.

96. Mega J. L., Hochholzer W., Frelinger A. L., 3rd, et al. Dosing clopidogrel based on CYP2C19 genotype and the effect on platelet reactivity in patients with stable cardiovascular disease // Jama, 2011; 306 (20): 2221-2228.

97. Mehta S. R., Bassand J. P., Chrolavicius S., et al. Dose comparisons of clopidogrel and aspirin in acute coronary syndromes // N Engl J Med, 2010; 363 (10): 930-942.

98. Michelson A. D. P2Y12 antagonism: promises and challenges // Arterioscler Thromb Vasc Biol, 2008; 28 (3): s33-38. 
99. Michelson A. D., Linden M. D., Furman M. I., et al. Evidence that pre-existent variability in platelet response to ADP accounts for 'clopidogrel resistance' // J Thromb Haemost, 2007; 5 (1): 75-81.

100. Moceri P., Doyen D., Cerboni P., Ferrari E. Doubling the dose of clopidogrel restores the loss of antiplatelet effect induced by esomeprazole // Thromb Res, 2011; $128(5): 458-462$.

101. Momary K. M., Dorsch M. P., Bates E. R. Genetic causes of clopidogrel nonresponsiveness: which ones really count? // Pharmacotherapy, 2010; 30 (3): $265-274$.

102. Morris A., Aliprandi-Costa B., Brieger D. Platelet function analysis: A comparison of methods // Int J Cardiol, 2009; 145 (1): 167-168.

103. Motovska Z., Widimsky P., Kvasnicka J., et al. High loading dose of clopidogrel is unable to satisfactorily inhibit platelet reactivity in patients with glycoprotein IIIA gene polymorphism: a genetic substudy of PRAGUE-8 trial // Blood Coagul Fibrinolysis, 2009; 20 (4): 257-262.

104. Nishio R., Shinke T., Otake H., et al. Paraoxonase-1 activity affects the clopidogrel response in CYP2C19 loss-of-function carriers // Thromb Res, 2013; 3848 (13): 0040800408 .

105. O'donoghue M., Wiviott S. D. Clopidogrel response variability and future therapies: clopidogrel: does one size fit all? // Circulation, 2006; 114 (22): e600-606.

106. Oestreich J. H., Smyth S. S., Campbell C. L. Platelet function analysis: at the edge of meaning // Thromb Haemost, 2009; 101 (2): 217-219.

107. Ojeifo O., Wiviott S. D., Antman E. M., et al. Concomitant Administration of Clopidogrel With Statins or Calcium Channel Blockers: Insights From the TRITONTIMI 38 (Trial to Assess Improvement in Therapeutic Outcomes by Optimizing Platelet 108. Inhibition With Prasugrel-Thrombolysis in Myocardial Infarction 38) Trial // JACC Cardiovasc Interv, 2013; 8798 (13): 01447-01447. 
109. Olesen J. B., Gislason G. H., Charlot M. G., et al. Calcium-channel blockers do not alter the clinical efficacy of clopidogrel after myocardial infarction: a nationwide cohort study // J Am Coll Cardiol, 2011; 57 (4): 409-417.

110. Pampuch A., Cerletti C., De Gaetano G. Comparison of VASP-phosphorylation assay to light-transmission aggregometry in assessing inhibition of the platelet ADP P2Y12 receptor // Thromb Haemost, 2006; 96 (6): 767-773.

111. Pankert M., Quilici J., Loundou A. D., et al. Impact of Obesity and the Metabolic Syndrome on Response to Clopidogrel or Prasugrel and Bleeding Risk in Patients Treated After Coronary Stenting // Am J Cardiol, 2013; 9149 (13): 01928-01920.

112. Papathanasiou A., Goudevenos J., Tselepis A. D. Resistance to aspirin and clopidogrel: possible mechanisms, laboratory investigation, and clinical significance // Hellenic J Cardiol, 2007; 48 (6): 352-363.

113. Pare G., Mehta S. R., Yusuf S., et al. Effects of CYP2C19 genotype on outcomes of clopidogrel treatment // N Engl J Med, 2010; 363 (18): 1704-1714.

114. Park Y., Jeong Y. H., Tantry U. S., et al. Accelerated platelet inhibition by switching from atorvastatin to a non-CYP3A4-metabolized statin in patients with high platelet reactivity (ACCEL-STATIN) study // Eur Heart J, 2012; 33 (17): 2151-2162.

115. Pettersen A. A., Arnesen H., Opstad T. B., Seljeflot I. The influence of CYP 2C19*2 polymorphism on platelet function testing during single antiplatelet treatment with clopidogrel // Thromb J, 2011; 9 (4): 4.

116. Polena S., Gupta M. P., Shaikh H., et al. Platelet aggregation inhibition in patients receiving statins either fully or partially metabolized by CYP3A4 // Proc West Pharmacol Soc, 2008; 51 60-62.

117. Poyet R., Cuisset T., Frere C., et al. Comparison of rosuvastatin and atorvastatin on clopidogrel response and lipidic and inflammatory parameters after coronary stenting for acute coronary syndrome: the prospective, randomized OSCAR study (optimal statin therapy with clopidogrel after coronary revascularisation) // Thromb Res, 2010; 126 (5): 397-399. 
118. Price M. J., Berger P. B., Teirstein P. S., et al. Standard- vs high-dose clopidogrel based on platelet function testing after percutaneous coronary intervention: the GRAVITAS randomized trial // Jama, 2011; 305 (11): 1097-1105.

119. Price M. J., Murray S. S., Angiolillo D. J., et al. Influence of genetic polymorphisms on the effect of high- and standard-dose clopidogrel after percutaneous coronary intervention: the GIFT (Genotype Information and Functional Testing) study // J Am Coll Cardiol, 2012; 59 (22): 1928-1937.

120. Pyrgakis V. N., Goudevenos J. A. Clopidogrel and cardiovascular diseases: recommendations for its correct use // Hellenic J Cardiol, 2010; 51 (1): 83-86.

121. Sangkuhl K., Shuldiner A. R., Klein T. E., Altman R. B. Platelet aggregation pathway // Pharmacogenet Genomics, 2011; 21 (8): 516-521.

122. Schmidt M., Johansen M. B., Maeng M., et al. Concomitant use of clopidogrel and statins and risk of major adverse cardiovascular events following coronary stent implantation // Br J Clin Pharmacol, 2012; 74 (1): 161-170.

123. Schmidt M., Johansen M. B., Robertson D. J., et al. Use of clopidogrel and calcium channel blockers and risk of major adverse cardiovascular events // Eur J Clin Invest, 2012; 42 (3): 266-274.

124. Scott S. A., Sangkuhl K., Gardner E. E., et al. Clinical Pharmacogenetics Implementation Consortium guidelines for cytochrome P450-2C19 (CYP2C19) genotype and clopidogrel therapy // Clin Pharmacol Ther, 2011; 90 (2): 328-332.

125. Serebruany V., Goto S. Clopidogrel and proton pump inhibitors: gastric protection at expense of vascular benefit? // Thromb Haemost, 2009; 101 (4): 607-609.

126. Shi S., Klotz U. Proton pump inhibitors: an update of their clinical use and pharmacokinetics // Eur J Clin Pharmacol, 2008; 64 (10): 935-951.

127. Shuldiner A. R., O'connell J. R., Bliden K. P., et al. Association of cytochrome P450 2C19 genotype with the antiplatelet effect and clinical efficacy of clopidogrel therapy // Jama, 2009; 302 (8): 849-857. 
128. Sibbing D., Koch W., Gebhard D., et al. Cytochrome 2C19*17 allelic variant, platelet aggregation, bleeding events, and stent thrombosis in clopidogrel-treated patients with coronary stent placement // Circulation, 2010; 121 (4): 512-518.

129. Sibbing D., Morath T., Stegherr J., et al. Impact of proton pump inhibitors on the antiplatelet effects of clopidogrel // Thromb Haemost, 2009; 101 (4): 714-719.

130. Siller-Matula J. M., Krumphuber J., Jilma B. Pharmacokinetic, pharmacodynamic and clinical profile of novel antiplatelet drugs targeting vascular diseases // $\mathrm{Br} \mathrm{J}$ Pharmacol, 2009; 159 (3): 502-517.

131. Siller-Matula J. M., Lang I., Christ G., Jilma B. Calcium-channel blockers reduce the antiplatelet effect of clopidogrel // J Am Coll Cardiol, 2008; 52 (19): 1557-1563.

132. Simon T., Bhatt D. L., Bergougnan L., et al. Genetic polymorphisms and the impact of a higher clopidogrel dose regimen on active metabolite exposure and antiplatelet response in healthy subjects // Clin Pharmacol Ther, 2011; 90 (2): 287-295.

133. Simon T., Verstuyft C., Mary-Krause M., et al. Genetic determinants of response to clopidogrel and cardiovascular events // N Engl J Med, 2009; 360 (4): 363-375.

134. Singla A., Antonino M. J., Bliden K. P., et al. The relation between platelet reactivity and glycemic control in diabetic patients with cardiovascular disease on maintenance aspirin and clopidogrel therapy // Am Heart J, 2009; 158 (5): 784 e781-786.

135. Small D. S., Farid N. A., Payne C. D., et al. Effects of the proton pump inhibitor lansoprazole on the pharmacokinetics and pharmacodynamics of prasugrel and clopidogrel // J Clin Pharmacol, 2008; 48 (4): 475-484.

136. Sofi F., Giusti B., Marcucci R., et al. Cytochrome P450 2C19*2 polymorphism and cardiovascular recurrences in patients taking clopidogrel: a meta-analysis // Pharmacogenomics J, 2010; 11 (3): 199-206.

137. Su J., Xu J., Li X., et al. ABCB1 C3435T polymorphism and response to clopidogrel treatment in coronary artery disease (CAD) patients: a meta-analysis // PLoS One, 2012; 7 (10): e46366. 
138. Sudhir K., Hermiller J. B., Ferguson J. M., Simonton C. A. Risk factors for coronary drug-eluting stent thrombosis: influence of procedural, patient, lesion, and stent related factors and dual antiplatelet therapy // ISRN Cardiol, 2013; 2013 (748736): 748736.

139. Suh J. W., Cha M. J., Lee S. P., et al. Relationship Between Statin Type and Responsiveness to Clopidogrel in Patients Treated with Percutaneous Coronary Intervention: A Subgroup Analysis of the CILON-T Trial // J Atheroscler Thromb, 2013; 201318.

140. Taubert D., Von Beckerath N., Grimberg G., et al. Impact of P-glycoprotein on clopidogrel absorption // Clin Pharmacol Ther, 2006; 80 (5): 486-501.

141. Toma N. Randomized double-blind assessment of the ONSET and OFFSET of the antiplatelet effects of Ticagrelor versus Clopidogrel in patients with stable coronary artery disease. The ONSET/OFFSET study // Maedica (Buchar), 2010; 5 (1): 75-76.

142. Trenk D., Hochholzer W., Frundi D., et al. Impact of cytochrome P450 3A4metabolized statins on the antiplatelet effect of a 600-mg loading dose clopidogrel and on clinical outcome in patients undergoing elective coronary stent placement // Thromb Haemost, 2008; 99 (1): 174-181.

143. Ueno M., Ferreiro J. L., Desai B., et al. Cigarette smoking is associated with a dose-response effect in clopidogrel-treated patients with diabetes mellitus and coronary artery disease: results of a pharmacodynamic study // JACC Cardiovasc Interv, 2012; 5 (3): $293-300$.

144. Varenhorst C., James S., Erlinge D., et al. Assessment of P2Y(12) inhibition with the point-of-care device VerifyNow P2Y12 in patients treated with prasugrel or clopidogrel coadministered with aspirin // Am Heart J, 2009; 157 (3): 562 e561-569.

145. Von Beckerath N., Sibbing D., Jawansky S., et al. Assessment of platelet response to clopidogrel with multiple electrode aggregometry, the VerifyNow P2Y12 analyzer and platelet vasodilator-stimulated phosphoprotein flow cytometry // Blood Coagul Fibrinolysis, 2009; 99. 
146. Von Beckerath N., Taubert D., Pogatsa-Murray G., et al. Absorption, metabolization, and antiplatelet effects of 300-, 600-, and 900-mg loading doses of clopidogrel: results of the ISAR-CHOICE (Intracoronary Stenting and Antithrombotic Regimen: Choose Between 3 High Oral Doses for Immediate Clopidogrel Effect) Trial // Circulation, 2005; 112 (19): 2946-2950.

147. Wallentin L., Becker R. C., Budaj A., et al. Ticagrelor versus clopidogrel in patients with acute coronary syndromes // N Engl J Med, 2009; 361 (11): 1045-1057.

148. Wallentin L., James S., Storey R. F., et al. Effect of CYP2C19 and ABCB1 single nucleotide polymorphisms on outcomes of treatment with ticagrelor versus clopidogrel for acute coronary syndromes: a genetic substudy of the PLATO trial // Lancet, 2010; 376 (9749): 1320-1328.

149. Wang T. H., Bhatt D. L., Topol E. J. Aspirin and clopidogrel resistance: an emerging clinical entity // Eur Heart J, 2006; 27 (6): 647-654.

150. Wang X. D., Zhang D. F., Zhuang S. W., Lai Y. Modifying clopidogrel maintenance doses according to vasodilator-stimulated phosphoprotein phosphorylation index improves clinical outcome in patients with clopidogrel resistance // Clin Cardiol, 2011; 34 (5): 332-338.

151. White C. M. A review of the pharmacologic and pharmacokinetic aspects of rosuvastatin // J Clin Pharmacol, 2002; 42 (9): 963-970.

152. Wijns W., Kolh P., Danchin N., et al. Guidelines on myocardial revascularization // Eur Heart J, 2010; 31 (20): 2501-2555.

153. Wijns K. P., Danchin N., Mario D. C., Falk V., Folliguet T., et al. Guidelines for Myocardial Revascularisation. // Eur Heart J, 2010; (31) 2051-2555.

154. Williams C. D., Cherala G., Serebruany V. Application of platelet function testing to the bedside // Thromb Haemost, 2009; 103 (1): 29-33.

155. Wiviott S. D., Braunwald E., Mccabe C. H., et al. Intensive oral antiplatelet therapy for reduction of ischaemic events including stent thrombosis in patients with acute coronary syndromes treated with percutaneous coronary intervention and stenting 
in the TRITON-TIMI 38 trial: a subanalysis of a randomised trial // Lancet, 2008; 371 (9621): 1353-1363.

156. Wiviott S. D., Braunwald E., Mccabe C. H., et al. Prasugrel versus clopidogrel in patients with acute coronary syndromes // N Engl J Med, 2007; 357 (20): 2001-2015.

157. Wiviott S. D., Trenk D., Frelinger A. L., et al. Prasugrel compared with high loading- and maintenance-dose clopidogrel in patients with planned percutaneous coronary intervention: the Prasugrel in Comparison to Clopidogrel for Inhibition of Platelet Activation and Aggregation-Thrombolysis in Myocardial Infarction 44 trial // Circulation, 2007; 116 (25): 2923-2932.

158. Yilmaz M. B., Cihan G., Guray Y., et al. Role of mean platelet volume in triagging acute coronary syndromes // J Thromb Thrombolysis, 2008; 26 (1): 49-54.

159. Zahno A., Brecht K., Bodmer M., et al. Effects of drug interactions on biotransformation and antiplatelet effect of clopidogrel in vitro // Br J Pharmacol, 2010; 161 (2): 393-404. 


\section{PUBLIKĀCIJAS UN ZIṆOJUMI PAR PĒTĪJUMA TĒMU}

\section{Publikācija par pētījuma tēmu starptautiski recenzētā izdevumā:}

Urtane I., Aitullina A., Pukite K. Clopidogrel and the possibility of drug-drug interaction in the primary health care. Journal of Young Pharmacists, 2013; 5:18.-21.

\section{Pieņemts publicēšanai starptautiski citētā zinātniskā izdevumā Medicina (Kaunas):} Latkovskis G., Urtane I., Knipse A., Peculis R., Cakstina I., Klovins J., Erglis A. Role of Genetic Factors on the Effect of Additional Loading Doses and Two Maintenance Doses Used to Overcome Clopidogrel Hyporesponsiveness.

\section{Publikācijas par pētījuma tēmu Latvijas recenzētos zinātniskos izdevumos:}

Šaļapina A., Štokmane A.S., Urtāne I. Klopidogrela un citu zāḷ vienlaicīgas lietošanas prevalence ambulatorā praksē farmaceita skatījumā. Rīgas Stradiṇa universitātes Zinātniskie raksti, 2012; 157.-162. lpp.

Urtāne I., Knipše A., Latkovskis G., Ērglis A. Trombocītu funkciju izvērtēšanas testu piemērotība antiagregantu terapijas efektivitātes novērtēšanai. Latvijas Universitātes raksti (Medicīna), 2011; 773. sēj.: 195.-204. lpp.

Meijere A., Urtane I., Stokmane A.S., Effect of concomitant used drugs on the antiplatelet therapy. Rīga Stradiņš University Collection of Scientific Papers 2011, 2011; 184.-190.

Publikācijas ar zināmu saistību pētījuma tēmai (līdzekḷi trombožu ārstēšanai un profilaksei):

Urtane I., Bandere D., Ansabergs J., Stokmane A.S. Role of Clinical Pharmacist in Anticoagulation Management. Medicinos (Theory and Practice in Medicine), 2012; 18 [Brandt et al.]: 189.-192.

Urtane I., Ansabergs J., Stokmane A.S. Role of Clinical Pharmacist in Anticoagulation Monitoring. Inventi Journals (Clinical Research), 2011; 1: 12.-14.

Urtane I., Ansabergs J., Stokmane A.S., Bandere D., Medne R. Analyses of Warfarin Interaction in Cardiology. Rīga Stradiņš University Collection of Scientific Papers 2010, 2011; 180.-184.

Urtāne I., Ansabergs J., Štokmane A.S., Bandere D. Personalizēta antikoagulantu terapija kardiolog̣ijā. Veterinārmedicīnas raksti, 2010; 136.-141. lpp. 


\section{Konferenču tēzes par pētījuma tēmu:}

Latkovskis G., Urtane I., Knipse A., Puceta L., Peculis R., Klovins J., Erglis A. Role of genetic factors on the effect of additional loading doses and two maintenance doses used to overcome clopidogrel hyporesponsiveness. 42th ESCP Synposium on Clinical Pharmacy, Prague, Czech Republic, October 16-18, 2013, Programme and abstract book, P. 77.

Latkovskis G., Urtane I., Knipse A., Puceta L., Peculis R., Klovins J., Erglis A. Role of genetic factors on the effect of additional loading doses and two maintenance doses used to overcome clopidogrel hyporesponsiveness. 6th Baltic Atherosclerosis Congress, Riga, Latvia, October 11-12, 2013. Program and abstracts, P. 30.

Latkovskis G., Urtane I., Knipse A., Puceta L., Peculis R., Klovins J., Erglis A. Role of genetic factors on the effect of additional loading doses and two maintenance doses used to overcome clopidogrel hyporesponsiveness. XXIV Nordic Baltic Congress of Cardiology 2013, Oslo, Norway, June 13-15, 2013. Final program, P. 7.

Urtane I., Pukite K., Aitullina A., Berzina S., Stokmane A.S. Prevalence of drug-drug interaction in the primary health care during clopidogrel therapy. 81th European Atherosclerosis Society Congress, Lyon, France, June 2-5, 2013. Final programme, P.113.

Urtane I., Meijere A., Stokmane A.S. Influence of co-administrated drugs on the antiplatelet therapy. 80th European Atherosclerosis Society Congress, Milan, Italy, 2528 May, 2012. Final programme, P. 103.

Latkovskis G., Knipse A., Urtane I., Puceta L., Bruvers P., Erglis A. Efficacy of additional loading doses in patients with high on treatment platelet reactivity. International Conference in Pharmacology, Riga, Latvia, 20-21 April, 2012. Abstract book, P. 60.

Puķīte K., Urtāne I., Štokmane A.S., Bērziņa S. Protonu sūkņa inhibitoru un klopidogrela iespējamā mijiedarbība kombinētās terapijas laikā. Rīgas Stradiņa universitātes Zinātniskā konference, 2012. gada 29.-30. marts. Tēzes, 128. lpp. 
Aitullina A., Urtāne I., Štokmane A.S. CYP3A4 inhibitoru ietekme uz klopidogrela terapiju. Rīgas Stradiṇa universitātes Zinātniskā konference, 2012. gada 29.-30. marts. Tēzes, 125. lpp.

Šalıapina A., Urtāne I., Štokmane A.S. Jaunākās paaudzes antiagregantu pielietojums farmaceita skatījumā. Rīgas Stradiṇa universitātes Zinātniskā konference, 2012. gada 29.-30. marts. Tēzes, 152.1pp.

Meijere A., Urtane I., Stokmane A.S. Effect of Concomitant Used Drugs on the Antiplatelet Therapy. LFB starptautiskā konference BaltPharmForum 2011, Ventspils, 27.-29.05.2011.

Latkovskis G., Knipse A., Urtane I., Bruvers P., Puceta L., Gustafsson A., Erglis A. High On-Treatment Platelet Reactivity and Effect of Additional Loading Doses of Clopidogrel in Patients Undergoing Percutaneous Coronary Intervention With Drug Eluting Stent. XXIII Nordic-Baltic Congress of Cardiology, Riga, Latvia, 16 - 18 June, 2011. Medicina (Suppl.), 2011; 47(1): P.15.

Latkovskis G., Knipše A., Urtāne I., Brūvers P., Gustafsson A., Ērglis A. Samazinātas klopidogrela efektivitātes riska faktori un novērtējums ar VASP metodi pacientiem pēc stenta implantācijas. Rīgas Stradiņa universitātes Zinātniskā konference 2011. Tēzes, 138.lpp.

Meijere A., Štokmane A.S., Urtāne I. Aspirīna iespējamās mijiedarbības izvērtēšana antiagregantu terapijas ambulatorajā praksē. Rīgas Stradiṇa universitātes Zinātniskā konference 2011. Tēzes, 174.lpp.

\section{Ziņojumi kongresos un konferencēs par pētījuma tēmu:}

Urtāne I., Latkovskis G., Knipše A., Pučeta L., Aitullina A., Ērglis A. Protonu sūkņa inhibitoru ietekme uz klopidogrela hiporesponsivitāti pacientiem pēc ar zālēm pārklāta stenta implantācijas. RSU 12. Zinātniskā konference, 2013. gada 21.-22. marts. Tēzes, 95.lpp.

Latkovskis G., Urtāne I., Knipše A., Pučeta L., Pečulis R., Kloviņš J., Ērglis A. Klopidogrela hiporesponsivitātes un rezistences sastopamība un veicinošie faktori 
pacientiem pēc DES stenta implantācijas. Latvijas Universitātes 71. Zinātniskā konference, Medicīnas sekcija, 2013. gada 15. februāris. Konferences programma, 44.lpp.

Latkovskis G., Urtāne I., Knipše A., Pučeta L., Gustafsson A., Brūvers P., Ërglis A. Papildus piesātinošo devu efektivitātes analīze pacientiem ar pazeminātu atbildes reakciju uz klopidogrela terapiju. Latvijas Universitātes 70. Zinātniskā konference (Medicīnas sekcija), 2012. gada 2. februāris. Tēzes, 41.lpp.

Latkovskis G., Knipše A., Urtāne I., Brūvers P., Gustafsson A., Ērglis A. Klopidogrela efektivitātes novērtējums ar VASP metodi pacientiem pēc stenta implantācijas - pirmā pieredze Latvijā. Latvijas Universitātes 69. Zinātniskā konference, Medicīnas sekcija, 2011. gada 3. februāris. Tēzes, 43. lpp.

\section{Konferenču tēzes ar zināmu saistību pētījuma tēmai (līdzekḷi trombožu ārstēšanai un profilaksei):}

Latkovskis G., Zabunova M., Berzina M., Urtane I., Zarakauska L., Erglis A. High sensitivity C-reactive protein levels are associated with total coronary artery occlusions. 6th Baltic Atherosclerosis Congress, Riga, Latvia, October 11-12, 2013. Program and abstracts, P. 28.

Latkovskis G., Zabunova M., Berzina M., Juhnevica D., Urtane I., Zarakauska L., Erglis A. High sensitivity C-reactive protein levels are associated with total coronary artery occlusions. 81th European Atherosclerosis Society Congress, Lyon, France, June 2-5, 2013. Final programme, P. 107.

Latkovskis G., Licis N., Juhnevica D., Berzina M., Zabunova M., Urtane I., Knipse A., Erglis A. Association of a common interleukin-6 promoter region haplotype with more stable initial course of coronary heart disease. XVI International Symposium on Atherosclerosis (ISA) 2012, Sydney, Australia, 25-29 March, 2012. Final program, Abstract No. 148.

Urtane I., Ansabergs J., Stokmane A. S., Bandere D., Medne R. Strategies of warfarin therapy in the elderly patients. XVI International Symposium on Atherosclerosis (ISA) 2012, Sydney, Australia, 25-29 March, 2012. Final program, Abstract No. 165. 
Latkovskis G., Licis N., Krivmane B., Liepins E., Dambrova M., Urtane I., Knipse A., Zabunova M., Berzina M., Erglis A. Effect of cyclooxygenase-1 polymorphisms on urinary 11-dehydrothromboxane B2 levels in patients undergoing stent implantation pretreated with aspirin. The 79th EAS Congress, 26-29 June, 2011, Gothenburg, Sweden. Atherosclerosis (Suppl.), 2011; 12(1), P. 110.

Urtane I., Ansabergs J., Stokmane A.S., Bandere D. Role of clinical pharmacist in anticoagulation management. $16^{\text {th }}$ Congress of EAHP, Viena, Austria, 30 March to 1 April 2011. Congress abstract book, P. 148.

Latkovskis G., Līcis N., Urtāne I., Zarakauska L., Zabunova M., Berzina M., Liepiṇš E., Dambrova M., Pečulis R., Kloviņš J., Ērglis A. Ģenētisko polimorfismu un antiagregantu rezistences marķieru asociācija ar mirstību pacientiem pēc perkutānas koronāras intervences ar zālēm pildītiem stentiem. Latvijas Universitātes 70. Zinātniskāa konference (Medicīnas sekcija), 2012. gada 2. februāris. Tēzes, 42.lpp. 


\section{PIELIKUMI}

\section{Paula Stradiṇa klīniskās universitātes slimnīcas \\ Attīstības biedrības \\ KLĨNISKĀS IZPĒTES ẼTIKAS KOMITEJA}

\section{Darbojas saskanāa ar SHK LKP noteikumiem \\ ATZINUMS Nr. 300610 - 2L}

1. Protokola nosaukums: Klopidogrela rezistences attīstības cêloṇi un klīniskā nozīme drošas un efektīvas terapijas nodrošināšanai

2. Protokola Nr.: nav

3. Pētnieka vārds, uzvārds, centra nosaukums un adrese:

Prof. A. Ērglis - Paula Stradiṇa Klīniskā universitātes slimnīca, Pilsoṇu iela 13, Rìga LV-1002, Latvija

4. Apstiprinātie dokumenti:

Pieteikums ētikas komitejai ar darba detalizētu aprakstu

Pacienta informācija un piekrišana līdzdalībai pētījumā latviešu un krievu valodā

Pētijuma gaitas atspogulojums (shematisks)

Pētījuma anketas datu ievākšanai (anamnēze)

$\mathrm{PCI}$ (perkutāna koronāra intervence) protokols

Anketa „Follow up viz̄̄te pēc 5 nedẹ|āàm” (novērojuma vizīte)

5. Ẽtikas komitejas atzinums: pozitīvs ar norādījumu: ievērot normatīvo aktu prasības par personu iesaistišsanu zinātniskajā izpētē un datu apstrādē

6. Ėtikas komitejas locekḷi, kuri piedalījās balsošanā:

Ilze Aizsilniece - gimenes ārste Inga Štrāle - filologs

Dainis Krieviṇš - asinsvadu ḳirurgs Irina Vinnika - biologs

Juris Pokrotnieks - gastroenterologs Daina Biseniece - k̦īmiḳe

Biruta Kupča - psihiatrs Pēteris Ersts - jurists

7. Ētikas komitejas sēdes datums: 2010. gada 30. jūmijijs

Ētikas komitejas priekšsēēētājs:

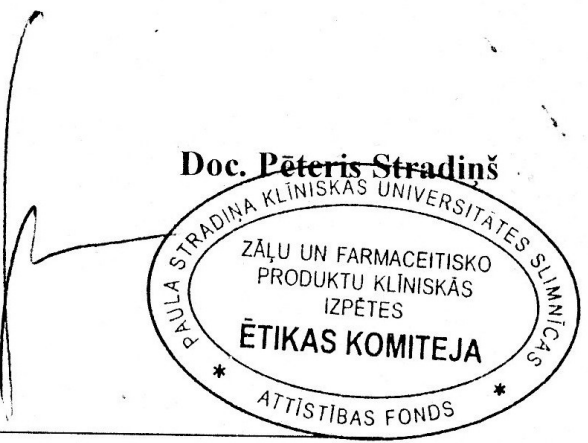

Paula Stradiṇa klīniskās universitātes slimnīcas Attīstības biedrība

Pilsoṇu 13, Riga, LV-1002, Tel. +371 7611353; Fax. +371 7069946, E - pasts: etikas-komiteja@stradini.Iv 


\title{
Centrālā medicīnas ētikas komiteja
}

\author{
Brivibas tela 72. Riga LV-101] • Täle. 67876182 • Fakss 67876071 • E-pasts: vm avm.gov,lv

$$
\text { Rigã }
$$

24.05.2011. Nr.01-29.1/11

\section{Sadarbibas projekta "Slimibu etiologijas, patogenenzes un cilvēka novecošanas procesu g̀enètiska izpēte Latvijas populäcijă" vadT̃täam Jănim Klovinุam.}

Atzinums Nr.01-29.1/1/ par pieteikuma projektuSadarbibas projekta "Slimibu etiologijas, patogenezes un cilvëka novecošanas procesu genëtiska iapëte Lanijas populäcijă" apakšprojektu .Koronäräs sirds slimibas molekulärä genëtika"

Centrälä medicinas ëtikas komiteja 2011.gada 24.maijä izskatĩa Sadarbibas projekta "Slimïbu ctiologijas, patogenēzes un cilvẻa novecošanas procesu genëtiska izpēte Latvijas populäcijä" vadītäja Jãna Klovina iesniegto pieteikuma projektu - Sadarbibas projekta "Slimibu etiologijas, patoǵenēzes un cilvẻka novecošanas procesu genëtiska izpēte Latvijas populäcijä" apakšprojektu Koronäräs sirds slimības molekulärä genētika".

Pamatojoties uz Centrālà medicñas ẽtikas komitejas 2011. gada 24.maija sëdes protokola Nr.2 punktu 4, Sadarbíbas projekta "Slimïbu etiologijias, patog̉enēzes un cilvēka novecošanas procesu genētiska izpēte Latvijas populäcijä" vaditäam Jänim Klovinam tiek izsniegts atzinums. ka iesniegtais pieteikuma projekts - Sadarbibas projekta "Slimibu etologijas, patoğenëzes un cilvëka novecosanas procesu ġenëtiska izpëte Latvijas populācijä" apakšprojekts „Koronärās sirds slimības molekulārã genëtika" nav pretrunä ar bioêtikas normäm.

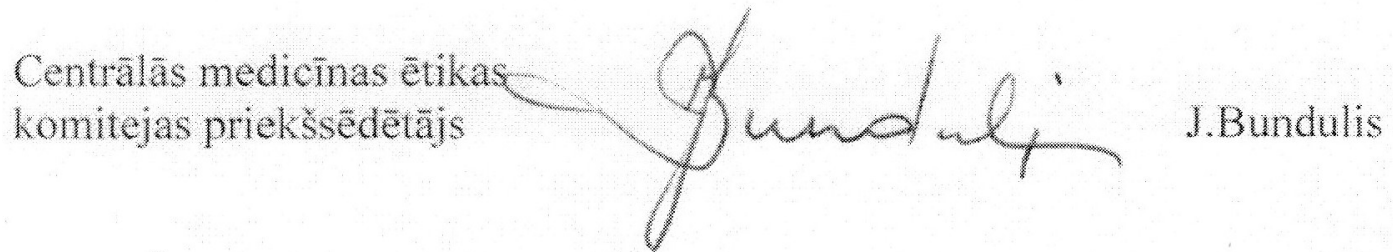

